\title{
AN INITIAL COMPARISON OF PITTING RESISTANCE OF ALLOYS FOR POTENTIAL GEOTHERMAL APPLICATIONS
}

\author{
Daniel Van Rooyen
}

May 1990

\author{
INFORMAL REPORT \\ DEPARTMENT OF NUCLEAR ENERGY
}

BROOKHAVEN NATIONAL LABORATORY ASSOCIATED UNIVERSITIES, INC. UPTON, LONG ISLAND, NEW YORK 11973 UNDER CONTPACT NO. DE-ACO2-76CH00016 WTH THE UNITED STATES DEPARTMENT OF ENERGY

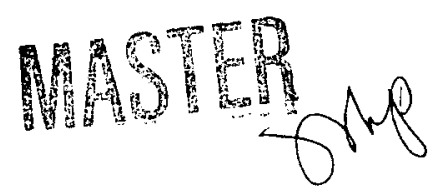




\section{DISCLAIMER}

This report was prepared as an account of work sponsored by an agency of the United States Government. Neither the United States Government nor any agency Thereof, nor any of their employees, makes any warranty, express or implied, or assumes any legal liability or responsibility for the accuracy, completeness, or usefulness of any information, apparatus, product, or process disclosed, or represents that its use would not infringe privately owned rights. Reference herein to any specific commercial product, process, or service by trade name, trademark, manufacturer, or otherwise does not necessarily constitute or imply its endorsement, recommendation, or favoring by the United States Government or any agency thereof. The views and opinions of authors expressed herein do not necessarily state or reflect those of the United States Government or any agency thereof. 


\section{DISCLAIMER}

Portions of this document may be illegible in electronic image products. Images are produced from the best available original document. 


\section{DISCLAIMER}

This report was prepared as an account of work sponsored by an agency of the United States Government. Neither the United States Government nor any agency thereof, nor any of their employees, not any of their contractors, subcontractors, or their employees, makes any warranty, express or implied, or assumes any legal liability or responsibility for the accuracy, completeness, or usefulness of any information, apparatus, product, or process disclosed, or represents that its use would not infringe privately owned rights. Reference herein to any specific commercial product, process, or service by trade name, trademark, manufacturer, or otherwise, does not necessarily constitute or imply its endorsement, recommendation, or favoring by the United States Government or any agency, contractor, or subcontractor thereof. The views and opinions of authors expressed herein do not necessarily state or reflect those of the United States Government or any agency, contractor or subcontractor thereof. 


\section{Abstract}

In order to use the energy available from geothermal sources, brines of a variety of compositions and temperatures have to be handled. Much of the hardware has consisted of metals, such as used in casings, pipes, valves, turbines, heat exchangers and others. When the $\mathrm{pH}$ is not very acid, and oxygen is absent, the brines are not very corrosive. However, there are instances where conditions cause accelerated corrosion. The present work was undertaken to examine one particular form of corrosion, pitting, which is encountered fairly often, and causes early failures in many industries because it is so localized.

A number of alloys have been examined in the laboratory for their resistance to pitting corrosion in chloride media. The electrochemical procedure of determining pitting potentials was used. It was found that the most meaningful results could be obtained by increasing the aggressiveness of the test solutions as the resistance to localized attack of individual members of the series of alloys increased. The outcome of the experiments was the creation of a ranking of a large number of alloys according to their performance in the laboratory test program. The range of materials tested include carbon steel at the low end, with Hastelloy C-276 and Titanium at the top. 
.

,

$\bullet$ 
Table of Contents

Page No.

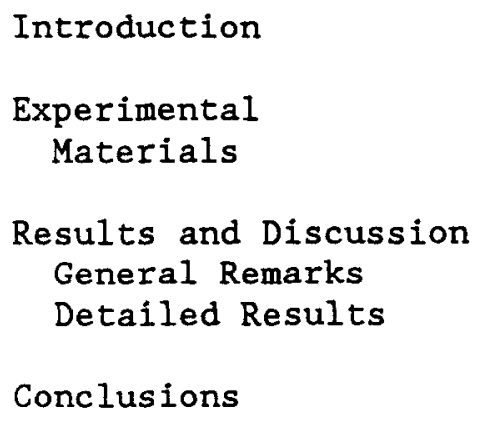

1

3

3

6

6

8

$12 \mathrm{a}$ 


\section{INTRODUCTION}

Materials used in the geothermal industry come in contact with a variety of environments depending on the particular region concerned. Some of the important variables that affect their corrosion performance include: dissolved salt concentration, temperature, pH, oxidizing species (Eh), organics (eg. isobutane with perhaps some entrained brine and air from time to time), and dissolved gases. Hot brine without oxygen and at a pH near neutral is usually not particularly corrosive but changing Eh or $\mathrm{pH}$, and especially the introduction of air, can raise the electrochemical potential sufficiently to make this liquid extremely corrosive. A lowering of pH such as may result from the presence of carbon dioxide is also quite adverse, and will also increase the corrosivity of the brine. In binary plants, the organic medium on the secondary side is not considered to be particularly corrosive when clean and uncontaminated. However, entrained brine and air will change this condition and at present it is not fully established how corrosive the secondary-side medium can become if small leaks should allow contamination to occur from the primary side to the secondary side. Under all conditions of increased aggressiveness, whether on the brine side or the secondary side, it becomes necessary to use materials that are sufficiently corrosion resistant to prevent outages due to corrosion failures. Apart from down-time, corrosion could also cause damage to expensive components that are used either below or above ground such as pumps, casing, valves, turbines, heat exchangers, condensers etc. The performance of materials in many cases is, still not fully evaluated. 
It is an unfortunate fact that the cost of metallic materials increases as their corrosion resistance increases. An ideal situation would be one where there is sufficient information on the performance of materials in a given environment to enable the selection of the lowest cost material that will still give satisfactory performance. Such an ideal case does not usually exist and the selection of material is still something of a groping process which relies largely on trial and error. It may be possible to design a plant that would be essentially corrosion free, by using the most corrosion resistant materials regardless of the environment in which they will have to perform, but this would make the plant so expensive that no one will be prepared to construct it.

The-present BNL program on metallic materials in the geothermal industry includes two programs, both at a low rate of effort. One deals with an exposure of coupons in the secondary medium of a binary plant (which will be the subject of a separate report), and the other with the laboratory determination of pitting corrosion resistance of a number of materials, ranging from the equivalent of carbon steel at the low end to Hastelloy $C$ and titanium at the upper end. This report covers the latter program in which electrochemical testing was done with the alloys concerned in an attempt to rank them according to pitting potentials; the objective is to provide a shopping list of alternate materials where and when they are needed.

The report shows that the technique's and procedures used were capable of distinguishing between the localized corrosion properties of the various alloys included in the program, and provided a basis for drawing up a so-called shopping list that was referred to in the previous paragraph. It 
should be emphasized that these laboratory tests do not tell specifically how well a given alloy will perform in a specific set of field conditions; rather it will indicate whether the selection of another alloy would be more likely to be successful in a case where a problem is encountered with a material used at present. It is also worth noting that our tests did not include an exhaustive list of available materials, rather it selectively chose alloys within the range we thought would be useful; if additional information is needed by the industry for a material that we did not include in our test it would be an easy matter to repeat the test and to include it in the rankings that we have put together so far.

\section{EXPERIMENTAL}

\section{Materials}

With three exceptions all the materials that were tested in this program were produced commercially and purchased from suppliers of metals. The three exceptions are: 1) the alloy with $32 \%$ chromium, $4 \%$ nickel and $2 \%$ molybdenum, 2) an alloy, also experimentally made, with $19.7 \%$ chromium, $26.8 \%$ nickel and $8.4 \%$ molybdenum, and 3 ) the experimental alloy No. 30 which contains $24 \%$ chromium, $20 \%$ nickel, $6 \%$ molybdenum and $0.44 \%$ nitrogen. Several of the alloys were heat treated before being cut into smaller pieces used as specimens for electrochemical testing. The details of the heat treatments are given in Table 1 together with the nominal or actual compositions of all the materials tested. In this Table when no heat treatment is indicated in the last column, the materials were in the as received condition without any further treatment in the laboratory. 
It is known(1) that the surface condition of a test specimen can have an important influence on the results obtained in the electrochemical tests for pitting corrosion. Consequently, the following procedure for specimen preparation was followed with all the materials. Strips of $1.25 \mathrm{~cm} \mathrm{x}$ $1.25 \mathrm{~cm}$ of each alloy were cut and a rod of Type 308 stainless steel was welded to one side. The rod was covered with rubber tubing except for the tip at the end away from the specimen. The specimens were mounted in epoxy, ground to 600 grit, and rinsed with distilled water, followed by acetone and absolute ethyl alcohol. The specimen/mount interface was next covered with a thin film of lacquer so that approximately $1 \mathrm{~cm}^{2}$ of each surface remained exposed. When not used immediately the specimens were stored in a desiccator until testing. The electrochemical procedure used followed ASTM Standards .

A typical cell that is used for this purpose is shown in Figure 1a. (2) The round bottom pyrex flask serves to hold the specimens as well as the test solution; provision is made for measuring the temperature, for connecting a salt bridge (in which the reference electrode is located and the tip of which extends to within a short distance of the test specimen), a gas inlet and outlet as well as an auxillary electrode. The capacity of the cell was 1 liter and approximately $800 \mathrm{cc}$ of test solution was used each time. After introducing the solution, the polarization cell temperature was set by means of a temperature controller and a heating mantle and the solution was deoxygenated with purified nitrogen which was passed at a rate of $90 \mathrm{ml}$ per minute starting at least 30 minutes before emmersion of the specimen. After this another 50 minutes were allowed to elapse before starting 
the anodic polarization at a rate of $6 \mathrm{ml}$ per minute.* Two systems were employed in this work. One was a Wenking potentiostat with an accompanying stepping potential controller which advanced the potential in discrete steps; the other apparatus was a PAR Model 350 Corrosion Measurement System which recorded the current and potential levels automatically and which had a built in scan system. The Wenking system was connected to a Hewlett Packard Model 7047-A XY recorder for recording the changes of potential and current density while the PAR system plotted the curve automatically from memory after the test had been completed.

In the results section it will be noticed that testing was carried out at different temperatures and with solutions of different acid and chloride ion concentrations. The reason for varying the test medium is that the alloys used in this program had a very large spread in their resistance to localized corrosion. Therefore, if one should have used, for instance, a very dilute sodium chloride at a neutral $\mathrm{pH}$ for the very resistant group consisting say of titanium, Hastelloy $C$ and alloy 625 , then not one of them would have shown a pitting potential below the end of the test where oxygen evolution and/or hexavalent chromium formation occur. For such a group of materials, then, it is necessary to use a higher temperature and a much more aggressive solution in order to distinguish between their relative resistances to pitting corrosion. At the other end of the scale, where the alloys have a very low resistance to pitting a much milder set of conditions is required in order to separate them from one another, since they would all look very poor in environments that are too aggressive.

* In some tests a lower rate was used, but groups of alloys that were close to one another were tested at the same rate so as to enable the data to be directly compared. The rate can influence the pitting potential. 
RESULTS AND DISCUSSION

General Remarks:

The major data in this report consist of current densities or potentials corresponding to specific aspects of the polarization behavior of the alloys tested. Specifically, the pitting potentials, critical current densities (onset of passivity), and passive current densities (rate of corrosion in the passive condition) are tabulated. The Figures provided in this report contain the actual data obtained in the electrochemical experiments. It will be noticed that as a result of doing the work at different times, involving different personnel, some of the curves have been drawn to eliminate irregularities that are considered to have little meaning ("smoothing out") while others were traced to include all the spikes and other "background" noise. This does not affect the values of the important data provided.

It is further worth repeating that, although the general rate of potential increase was approximately $6 \mathrm{mv} / \mathrm{min}$, some tests were done a little slower. This can affect the values obtained to some degree, with higher stepping or sweeping rates usually giving somewhat but not drastically higher pitting potentials. However, within a given Table or specific groups of alloys tested in the same environment, test conditions were not varied, so that relative comparisons and ranking of the alloys would not be distorted.

Some of the data given here were made available in earlier work (Ref. 1).

In very few instances, the ranking of an alloy did not remain the same relative to its neighbor when comparing tests of varying aggressiveness in terms of chloride ion concentration, temperature, and/or $\mathrm{pH}$ level. In such 
cases, the final ranking was based on an overall evaluation, or, where this was not clear, on the performance in the more aggressive solutions.

A final point to clarify is whether this particular test procedure is providing data that will apply directly to the relative performance of alloys under a variety of practical conditions. The answer is that no substitute test can give such an answer with certainty. There are several laboratory tests designed to determine, for instance:

1. The lowest temperature at which pitting starts in a given solution at a fixed potential.

2. The protection potential at which an active pit will stop growing. 3. The potential that is just low enough to allow the repair of a passive film that is mechanically disrupted.

4. Chemical concentration/temperature combinations that cause pitting, eg. a $\mathrm{FeCl}_{3}$ or $\mathrm{CuCl}_{2}$ solution.

5. The concentration of chloride ions that just cause pitting to initiate at a given potential and temperature.

In addition to these tests, there are many others in which longer-term exposures are made in simulated or actual anticipated environments.

All of the above methods will not necessarily give exactly the same ranking of alloys. However, there seems to be a remarkably consistent trend, associated with alloy composition, that stays consistent regardless of the exact test employed. The components in an alloy usually cost more, and often considerably more, than iron. 
Detailed Results

The sequence of Tables and Figures* in this report is intended to follow an increasing aggressiveness of the various media used. As was already explained, the need for changing the test was due to the fact that no single test could distinguish between all the groups of alloys well enough, i.e., the more resistant alloys all passed tests in mild solutions equally well, and the poorer alloys all failed badly under the most aggressive conditions.

Table 1 gives the actual or nominal compositions of the alloys.

Table 2 shows that a $1 \mathrm{~N} \mathrm{NaCl}$ solution separates the lower alloys quite well, with steel A285 corroding rapidly with increased potential while the most highly alloyed materials in the group, eg. AL-6X showed no attack. In this group, Alloy 825 gave a result that seems too low, and it is expected that other heats of this material would show a higher pitting potential than $300 \mathrm{mv}$. This is based on a comparison with values in the $40^{\circ} \mathrm{C} \mathrm{NaCl}$ test (Table 3 ) and the acidified $\mathrm{NaCl}$ tests (Table 7) both of which are more aggressive than the R.T. NaCl solution. Table 2 also shows that the common varieties of stainless steels show the following sequence of increasing resistance to pitting:

$410<304<316$.

When the temperature of the $1 \mathrm{~N} \mathrm{NaCl}$ solution is increased to $50^{\circ} \mathrm{C}$, pitting resistance decreases, but the stainless steels remain in the same order Type $410<304<316$. The other 3 alloys come quite clearly in the order: alloy $825<$ Hastelloy $G<A L-6 X$. Table 4 shows the ferritic steels

* Note: Figure numbers are given in the first column of each of Tables 2 through 10 . 
in the order: Type $410<409<430$, and it is believed that Type 430 is superior because it contains more $\mathrm{Cr}$. The austenitic Type 304 stainless steel was better than the straight $\mathrm{Fe}-\mathrm{Cr}$ alloys.

Tables 5 and 6 give the data for dilute $\mathrm{HCl}$ tests at $40^{\circ} \mathrm{C}$, which show that E-Brite $26-1$ is superior to Type 304 stainless steel, that Type 201 is about the same as Type 304, while Type 316 is better still (2 to $3 \% \mathrm{Mo}$ effect) and the nitrogen content of Type 316 LHP seems to improve its resistance a bit over "ordinary" Type 316. Most of the data were obtained in acidified $\mathrm{NaCl}$ (usually $0.5 \mathrm{~N} \mathrm{HCl}$ and $1 \mathrm{~N} \mathrm{NaCl}$ solution) at temperatures from $25^{\circ}$ to $90^{\circ} \mathrm{C}$. In this more aggressive environment it was impossible to distinguish between the pitting resistance of alloys that were less resistant than Type 316 stainless steel, as shown in Tables 7 and 8 . The 17-4 pH alloy showed no passivity, and Types 410 and 304 were similarly highly corroded as the electrochemical potential was increased. Type 316 stainless steel had only very short-lived passivity and pitted at a low potential $(-120 \mathrm{mv})$. The Sandvik alloy $2 \mathrm{RE} 60$ was somewhat inferior to alloy 825 which in turn was a little below the resistance of Hastelloy $G$. At $25^{\circ} \mathrm{C}$ in the hydrochloric acid/sodium chloride mixture all the alloys from E-Brite 26-1 through titanium Code-12 showed no pitting and the breakout potentials above $800 \mathrm{mv}$.

A higher temperature $\left(50^{\circ} \mathrm{C}\right)$ separated the more resistant alloys from one another quite effectively up to the level of alloys MP35N and the 29-4 Cr-Mo alloy. In this test it was evident that E-Brite and 316 stainless steel did not become passive at all while the Sandvik alloy 2 RE60, together with two others from Sandvik, 2RN65 and 2RK65 were superior. Above this level, starting with Jessop 700 through the titanium materials, the 
composition continued to have a strong effect on the performance of the materials. Again chromium and molybdenmum were the most obvious beneficial additions while there may be an effect resulting from such elements as columbium, tungsten and perhaps cobalt. The alloys with resistance equivalent to the 29-4 Cr-Mo material upwards were not separated too well in this medium since none of them showed any pitting corrosion; therefore a few experiments were done where either the temperature was raised to $70^{\circ}$ and $90^{\circ} \mathrm{C}$ or the sodium chloride was increased to $2 \mathrm{~N}$. These data are given in Tables 9 and 10. The first observation from Table 9 is the sharp division between the first three alloys and the rest. AL-6X, as well as alloy 825 had to be taken to very high current densities before there was any sign of a critical current density; in fact AL-6X cannot really be considered as having shown true passivity. Alloy 825 had great difficulty becoming passive, requiring a critical current density of $12,500 \mathrm{microamps} / \mathrm{cm}^{2}$, which is not considered to be a point that can be surpassed simply by immersing the alloy in the solution in its active state; the only way in which passivity can be achieved here is through the use of electrochemical equipment such as the potentiostat. In the group of the first three alloys, therefore, Hastelloy G, which at least showed some passivity, has to be ranked the highest with AL-6X (in this particular medium) the lowest. The 29-4 alloy (with $29 \%$ chromium and $4 \%$ molybdenum) had a pitting potential of 790 millivolts which is quite high and shows considerable resistance to breakdown of the passive film in this hot acidified chloride medium. The drawback of this alloy is also in the critical current density that is required in acid media. This phenomenom was already evident in Table 8 which shows a 
critical current density at $50^{\circ} \mathrm{C}$ of $10,000 \mathrm{microamps} / \mathrm{cm}^{2}$. The interpretation of these high current densities is that, once the alloy is active, such as can be achieved by scratching it or damaging the passive film that is present on the surface, the repair of the film will be exceptionally difficult when the $\mathrm{pH}$ is low and the rest of the medium is as aggressive as we have here; such conditions are not very likely to exist in a geothermal brine; it is highly likely that this artificial test is so severe that this alloy appears as if it would remain active whereas in the field we believe it has a very good chance of providing very good general corrosion and pitting resistance. To complete this discussion, it should be stated that the critical current density has been found, in general, to decrease as alloying additions such as nickel are made to the alloy; it is evident that the nickel base alloys or the alloys with a considerable nickel content are much easier to passivate in the acid media with relatively high chloride content. For example, in Table 9 and in Figure 56 alloy 625 shows a relatively low critical current density ( 375 microamps $/ \mathrm{cm}^{2}$ ) a passive current density of only 3 to 4 microamps $/ \mathrm{cm}^{2}$ and a pitting potential which is high, i.e. in the vicintiy of 700 millivolts. In contrast, alloy 29-4 showed some hysteresis in the polarization curve (alloy 625 did not do so) and it is believed that 625 will therefore be more resistant to pitting corrosion than will be alloy 29-4. It was very difficult to distinguish between Hastelloy C-276, the experimental alloy 30 , which is cheaper and contains a lower alloying content and has a relatively high nitrogen content, and also the titanium alloys that were included in this test medium. All of these materials showed pitting potentials greater than 800 millivolts and had acceptable 
critical current densities together with relatively low or very low passive current densities. Table 10 gives the results that were obtained with a solution of $0.5 \mathrm{~N} \mathrm{HCl}$ and $2 \mathrm{~N} \mathrm{NaCl}$ at a temperature of $70^{\circ} \mathrm{C}$. Again, the pitting potentials were above 800 millivolts for all three of these most resistant alloys, and it was not clear which one would be the most or the least pitting resistant. As a group they clearly stand at the highest end of resistance to pitting corrosion in our test program. Table 11 lists the overall ranking of all the alloys we used. 


\section{CONCLUSIONS}

1. Of the alloys used in this program, steel A285 had the lowest breakout potential and least passivity.

2. A partial ranking of the lower alloyed ferritic stainless steels shows Types 409 and 410 less resistant than 430. E-Brite 26-1 was more resistant, and the $29 \% \mathrm{Cr}-4 \%$ Mo material much superior in this group of non-austenitic stainless alloys. All these alloys had a much higher critical current density, i.e. passivated with much greater difficulty than the corresponding Ni-containing materials with roughly equivalent pitting resistance.

3. The austenitic stainless alloys increased in resistance as the alloying amounts of $\mathrm{Cr}$ and Mo increased, and there were signs that some other alloying additions were also effective.

4. To separate the resistances of different alloys effectively, the tests have to be done in solutions of specially adjusted aggressiveness. If this is not done, some non-identical alloys can appear to be equally bad (solution too aggressive) or equally very good (solution too mild).

5. - The "middle" group of alloys superior to the common grades of austenitic stainless steels included alloy 825, AL-6X, Hastelloy G.

6. Superior to the alloys above were, in order of increasing resistance to pitting, MP35N, 29-4, alloy 625, Hastelloys 276 and 276-C, an experimental alloy (developed under the geothermal program) with lower alloying additions than Hastelloy $\mathrm{C}$ but with high $\mathrm{N}$ content, titanium and Ti-code 12 .

7. Additional alloys of interest can be tested readily and added to the ones already listed in this report. 
TABLE 1

COMPOSITION AND CONDITION

Percent Composition

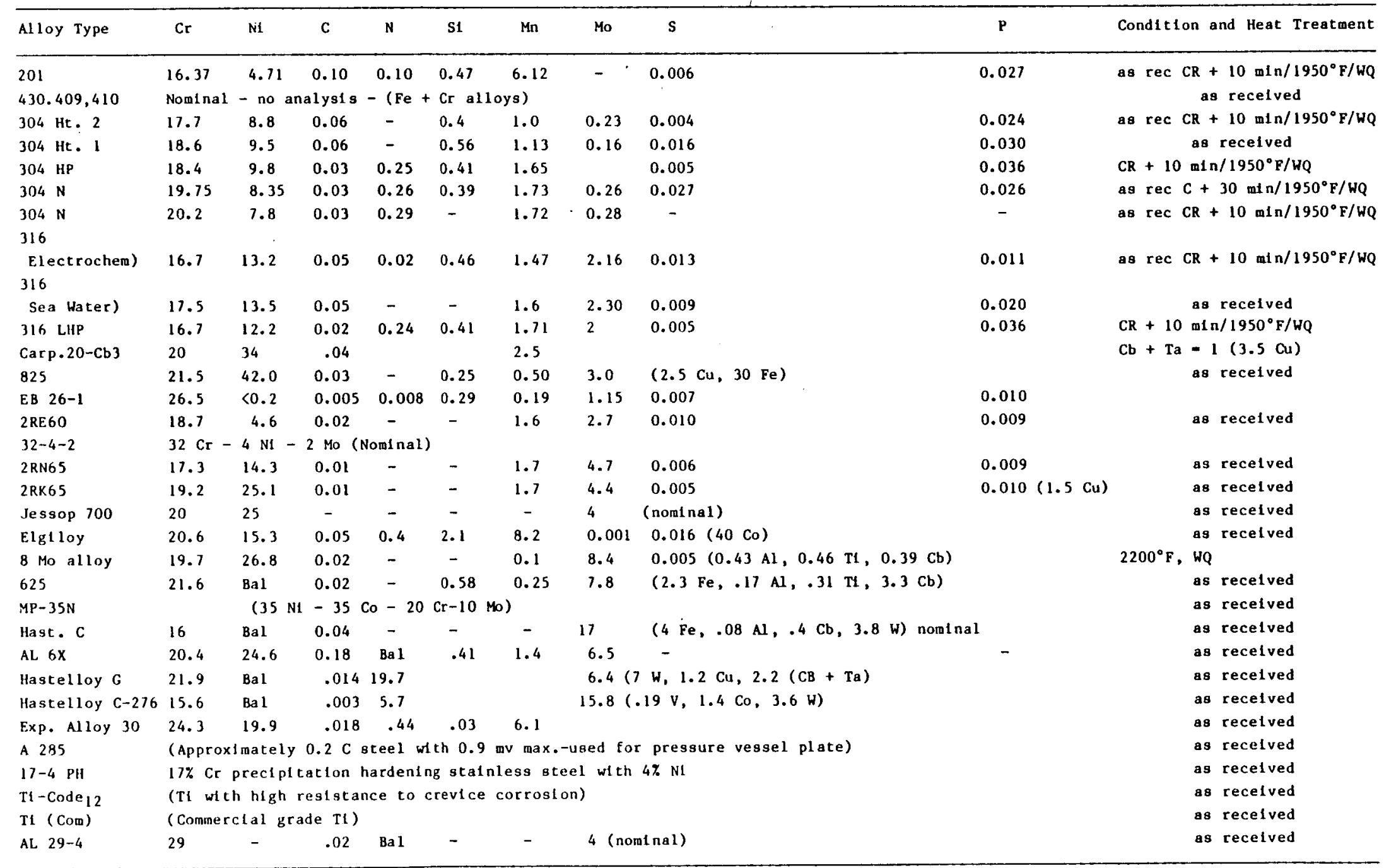


TABLE 2

\begin{tabular}{|c|c|c|c|c|c|}
\hline & & Solution & $: \quad 1 \mathrm{~N} \mathrm{NaCl}$ & Temperature: $22^{\circ}-$ & \\
\hline $\begin{array}{l}\text { Fig. } \\
\text { No. }\end{array}$ & Al loy & $\begin{array}{c}\text { Pitting } \\
\text { Potential, mv. } \\
\quad(\mathrm{SCE})\end{array}$ & $\begin{array}{l}\text { Critical* } \\
\text { Current } \\
\text { Density, } \mu_{\mathrm{A}} / \mathrm{cm}^{2}\end{array}$ & $\begin{array}{l}\text { Passive } \\
\text { Current } \\
\text { Density, } \mu_{\mathrm{A} / \mathrm{cm}^{2}}\end{array}$ & Reinarks \\
\hline 1 & A285 & -490 & - & 20 & Very little passivity \\
\hline 2 & 410 & -190 & - & $1-5$ & Very short passive region \\
\hline 3 & 2RE60 & 0 & - & $<1$ & \\
\hline 4 & 304 & 195 & - & 1 & \\
\hline 5 & 316 & 350 & - & $1-3$ & \\
\hline 6 & 825 & $300 * *$ & - & 1 & \\
\hline 7 & Carp. 20-Cb3 & $190-400$ & - & 1 & $\begin{array}{l}\text { One curve not shown in } \\
\text { Figure } 5\end{array}$ \\
\hline 8 & Hast $G$ & 750 & - & $1-2$ & No hysteresis on pitting \\
\hline 9 & $29-4$ & 800 & - & $7-3$ & No hysteresis on pitting \\
\hline 10 & AL $6 \mathrm{X}$ & $\begin{array}{l}\text { not clearly defined } \\
\text { C.D. }=3 \mu \mathrm{A} / \mathrm{cm}^{2} \max . \\
\text { at } 800 \mathrm{mv} .\end{array}$ & - & $3-5$ & $\begin{array}{l}\text { No evidence of pitting } \\
\text { eventhough current increased } \\
\text { from } 0.3 \text { to } 5 \mu \mathrm{A} \text { in passive } \\
\text { range }\end{array}$ \\
\hline
\end{tabular}

* No capital currents recorded because the solution was near neutral and a clear value is not obtained.

** By comparison with other data, eg. Fig. l6, this value is probably too low for this $1 \mathrm{~N}$ NaCl test. other heats are expected to provide higher values but tests were not done. 
TABLE 3

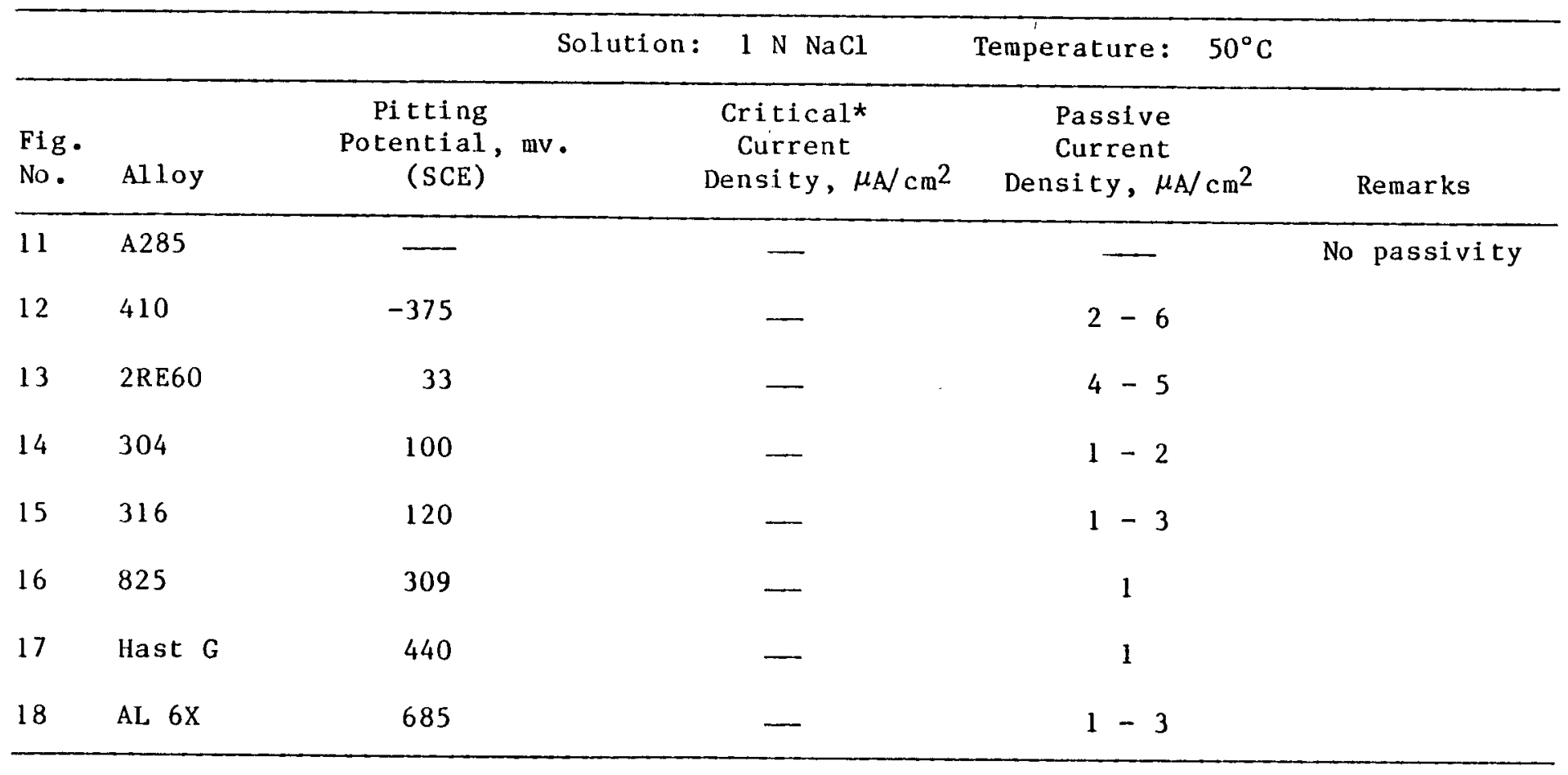

* No critical current densities reported because solution was near neutral. 
TABLE 4

\begin{tabular}{|c|c|c|c|c|c|c|}
\hline & & & Solution: & $\begin{array}{l}1 \mathrm{~N} \mathrm{H}_{2} \mathrm{SO}_{4} \\
1 \mathrm{~N} \mathrm{NaCl}^{2}\end{array}$ & \multicolumn{2}{|c|}{ Temperature: $22^{\circ}-25^{\circ} \mathrm{C}$} \\
\hline $\begin{array}{l}\text { Fig. } \\
\text { No. }\end{array}$ & Alloy & $\begin{array}{r}\text { Pitting } \\
\text { Potential, } \\
\text { (SCE) }\end{array}$ & mov. & $\begin{array}{l}\text { Critical } \\
\text { Current } \\
\text { Density, } \mu_{\mathrm{A}} / \mathrm{cm}^{2}\end{array}$ & $\begin{array}{c}\text { Passive } \\
\text { Current } \\
\text { Density, } \mu_{\mathrm{A}} / \mathrm{cm}^{2}\end{array}$ & Remarks \\
\hline 19 & 410 & - & & 一 & - & No passivity \\
\hline 19 & 409 & - & & 33,000 & 30,000 & No actual "passivity" \\
\hline 19 & 430 & -207 & & 8,300 & 380 & Short-lived passivity \\
\hline 19 & 304 & -100 & & 5,000 & 10 & Short-lived passivity \\
\hline
\end{tabular}




\section{TABLE 5}

\begin{tabular}{lcccc}
\hline & & Solution: & $0.25 \mathrm{~N} \mathrm{HCl}$ & Temperature: $40^{\circ} \mathrm{C}$ \\
\hline $\begin{array}{l}\text { Fig. } \\
\text { No. }\end{array}$ & $\begin{array}{c}\text { Pitloy } \\
\text { Potential } \\
(\mathrm{SCE})\end{array}$ & $\begin{array}{c}\text { Critical* } \\
\text { Current } \\
\text { Density, } \mu_{\mathrm{A} / \mathrm{cm}^{2}}\end{array}$ & $\begin{array}{c}\text { Passive } \\
\text { Current } \\
\text { Density, } \mu_{\mathrm{A} / \mathrm{cm}^{2}}\end{array}$ \\
\hline 20 & 304 & -190 & 2,000 & 60 \\
20 & E-brite $26-1$ & -80 & 8,000 & 30 \\
\hline
\end{tabular}


TABLE 6

\begin{tabular}{llcccc}
\hline \multicolumn{7}{c}{ Solution: $0.3 \mathrm{~N} \mathrm{HCl}$} & Temperature: & $40^{\circ} \mathrm{C}$ \\
\hline $\begin{array}{l}\text { Fig. } \\
\text { No. }\end{array}$ & $\begin{array}{c}\text { Pitting } \\
\text { Potential, } \\
\text { (SCE) }\end{array}$ & $\begin{array}{c}\text { Critical* } \\
\text { Current } \\
\text { Density, } \mu \mathrm{A} / \mathrm{cm}^{2}\end{array}$ & $\begin{array}{c}\text { Passive } \\
\text { Current } \\
\text { Density, } \mu_{\mathrm{A}} / \mathrm{cm}^{2}\end{array}$ & Remarks \\
\hline 21 & 304 & -190 & 2,000 & 500 & Short-lived passivity \\
21 & Duplex Steel & -190 & 600 & 10 & Short-lived passivity \\
22 & 201 & -190 & 710 & 30 & Short-lived passivity \\
21,22 & 316 & -160 & 95 & 4 & \\
22 & 316 LHP & -130 & 95 & 2 & \\
\hline
\end{tabular}




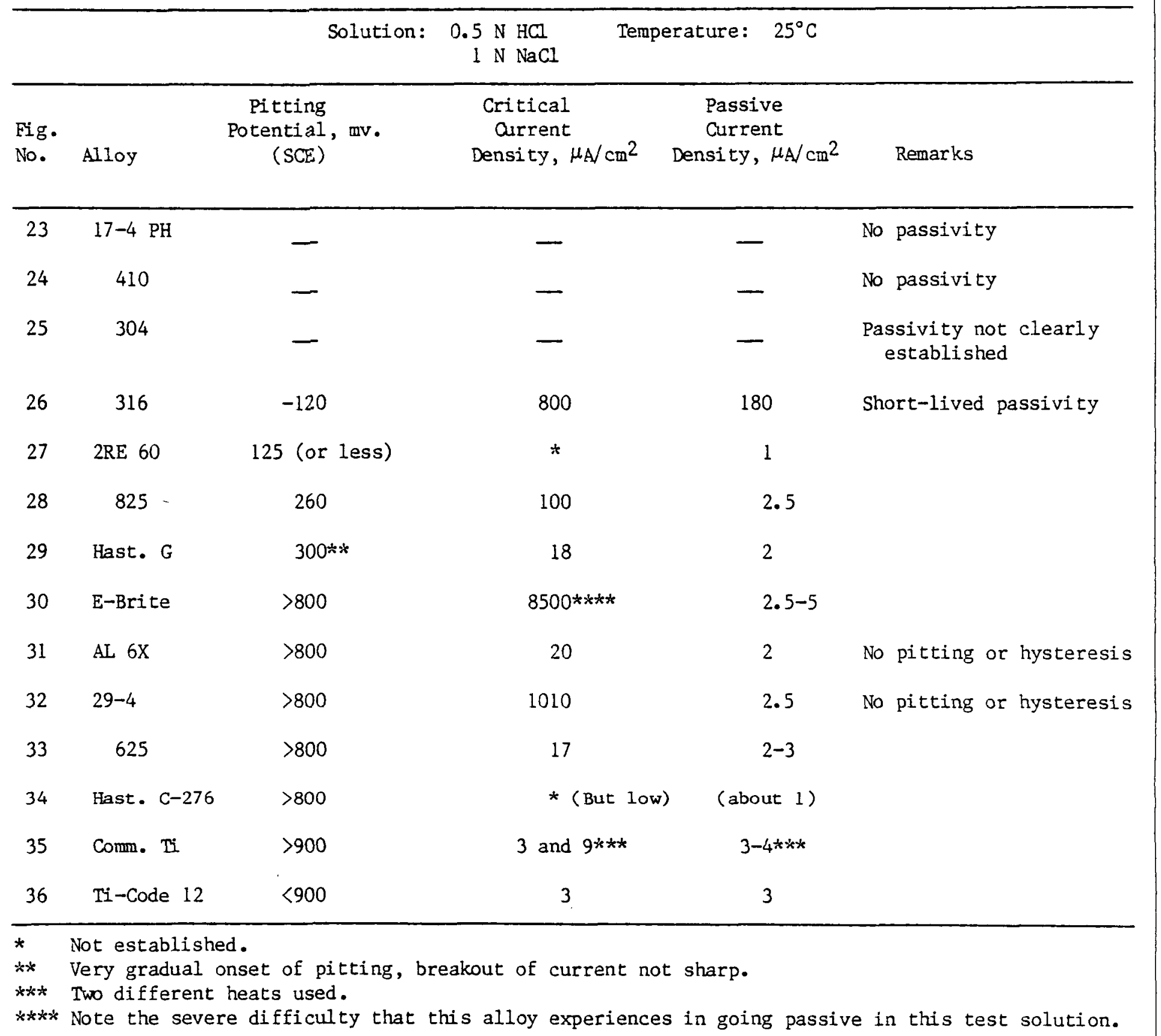


TABLE 8

\begin{tabular}{|c|c|c|c|c|c|}
\hline & & Solution: & $\begin{array}{r}0.5 \mathrm{~N} \mathrm{HCl} \\
1 \mathrm{~N} \mathrm{NaCl}\end{array}$ & erature: $50^{\circ} \mathrm{C}$ & \\
\hline $\begin{array}{l}\text { Fig. } \\
\text { No. }\end{array}$ & Alloy & $\begin{array}{l}\text { Pitting } \\
\text { Potential, mv. } \\
\text { (SCE) }\end{array}$ & $\begin{array}{l}\text { Critical } \\
\text { Current } \\
\text { Density, } \mu_{\mathrm{A}} / \mathrm{cm}^{2}\end{array}$ & $\begin{array}{c}\text { Passive } \\
\text { Current } \\
\text { Density, } \mu_{\mathrm{A}} / \mathrm{cm}^{2}\end{array}$ & Remarks \\
\hline 37 & E-Brite & 一 & - & — & No passivity \\
\hline 37 & 316 & - & - & - & No passivity \\
\hline 37 & Expt. $32 \mathrm{Cr}$ & -260 & 2800 & $<10$ & \\
\hline 37 & 825 & $10,100,220 *$ & 280 & 4 (and above) & \\
\hline 38 & $2 \mathrm{RN} 65$ & -140 & 1900 & 290 & \\
\hline 38 & $2 \mathrm{RK} 65$ & -115 & 1050 & $<10$ & \\
\hline 38 & Jessop 700 & -60 & 490 & 20 & \\
\hline 39 & Carp. $20 \mathrm{Cb} 3$ & 0 & 550 & 550 & Little passivity \\
\hline 38,45 & Expt. 8.0-8.5 Mc & 95 & 55 & $<10$ & \\
\hline 39 & $2 \mathrm{RE} 60$ & -290 & 5000 & 300 & Short-lived "passivity" \\
\hline 41 & $A L-6 X$ & 260 & 300 & 3 & \\
\hline 42 & Hast. G & 320 & 150 & 3 & \\
\hline 43,44 & $29-4$ & $735,>800$ & 40,10000 & $1-8$ & $\begin{array}{l}\text { No pitting or hysteresis } \\
\text { In one case, some } \\
\text { evidence of } 2 \text { phase. }\end{array}$ \\
\hline 45 & MP35 N & 400 & 50 & $<1$ & \\
\hline 45 & 625 & 770 & 55 & $<1$ & \\
\hline 45 & Hast. C & $750-800$ & 25 & $<1$ & No pitting or hysteresis \\
\hline 46 & Hast. C-276 & $>800$ & 9 & $7-9$ & \\
\hline 47 & Ti-Code 12 & $>900$ & 2 & 2 & \\
\hline
\end{tabular}

* Alloy 825 showed a range of values up to $220 \mathrm{mv}$. when several heats were tested. Surface conditic and processing of the alloy may be responsible for the variation, and this may be the border line of aggressive solution in which passivity can be induced. Carpenter $20 \mathrm{Cb} 3$ is showing signs of similar behavior. 


\section{TABLE 9}

\begin{tabular}{|c|c|c|c|c|c|}
\hline & & Solutior & $\begin{array}{rll}0.5 & \mathrm{~N} & \mathrm{HCl} \\
1 & \mathrm{~N} & \mathrm{NaCl} 1\end{array}$ & Temperature: & $70^{\circ} \mathrm{C}$ \\
\hline $\begin{array}{l}\text { Fig. } \\
\text { No. }\end{array}$ & Alloy ${ }^{\text {Pot }}$ & $\begin{array}{l}\text { Pitting } \\
\text { tential, mv. } \\
\quad(S C E)\end{array}$ & $\begin{array}{c}\text { Critical } \\
\text { Current } \\
\text { Density }, \mu \mathrm{A} / \mathrm{cm}^{2}\end{array}$ & $\begin{array}{c}\text { Passive } \\
\text { Current } \\
\text { Density, } \mu \mathrm{A} / \mathrm{cm}^{2}\end{array}$ & Remarks \\
\hline 48 & $A L-6 \mathrm{X}$ & (b) & $\cdots$ & $\cdots$ & Poor "passivity" or none \\
\hline 49 & 825 & 75 & 12,500 & 40 & Short-lived passivity. \\
\hline 50 & $29-4$ & 790 & $\begin{array}{l}42,500 * \\
\text { and } 200\end{array}$ & 23 & $\begin{array}{l}\text { Some hysteresis. } \\
\text { Probable pitting. }\end{array}$ \\
\hline 51 & 625 & 750 & 375 & $3-4$ & $\begin{array}{l}\text { No hysteresis. Probably } \\
\text { no pitting. }\end{array}$ \\
\hline 52 & $\begin{array}{l}\text { Hast. } \\
c-276\end{array}$ & $>800$ & 200 & $10-30$ & \\
\hline 52 & $\begin{array}{l}\text { Exper: } \\
\text { Alloy } 30\end{array}$ & $>800$ & 800 & $3-10$ & \\
\hline 53 & $\begin{array}{l}\mathrm{Ti} \text { - Code } \\
12\left(90^{\circ} \mathrm{C}\right)\end{array}$ & $\underline{2}^{>850}$ & 10 & $20-100$ & \\
\hline
\end{tabular}

* Evidence of duplex behavior, values are for 2 peaks in some test.

(a) No curve - shape similar to the other Ti-Code 12 curves on this page.

(b) Not a very meaningful number in view of the high rate of corrosion in the very limited "passive" of the curve. 
TABLE 10

\begin{tabular}{|c|c|c|c|c|c|}
\hline & & Solution: & $\begin{array}{l}0.5 \mathrm{~N} \mathrm{HCl} \\
2 \mathrm{~N} \mathrm{NaCl}\end{array}$ & erature: $70^{\circ} \mathrm{C}$ & \\
\hline $\begin{array}{l}\text { Fig. } \\
\text { No. }\end{array}$ & Alloy & $\begin{array}{l}\text { Pitting } \\
\text { Potential, mv. } \\
\text { (SCE) }\end{array}$ & $\begin{array}{l}\text { Critical } \\
\text { Current } \\
\text { Density, } \mu_{\mathrm{A}} / \mathrm{cm}^{2}\end{array}$ & $\begin{array}{c}\text { Passive } \\
\text { Current } \\
\text { Density, } \mu \mathrm{A} / \mathrm{cm}^{2}\end{array}$ & Remarks \\
\hline 54 & Hast. G & -120 & 5000 & 750 & Almost no passivity. \\
\hline 54 & Hast. C-276 & $>800$ & 1100 & $90-200$ & \\
\hline 54 & Expt. Alloy 30 & $>800$ & 2000 & 3 & \\
\hline 55 & Ti-Code 12 & $>900$ & 26 & $7-10$ & \\
\hline
\end{tabular}


Table 11

Relative Ranking of Alloys to Pitting Attack

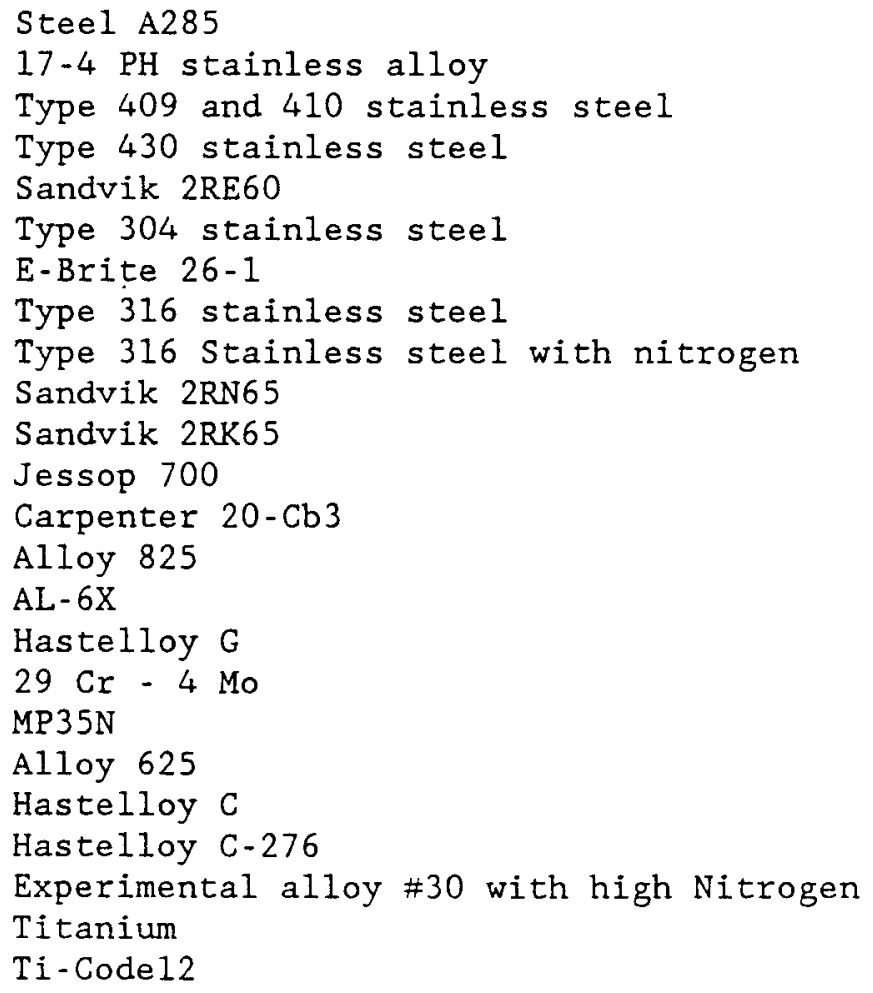




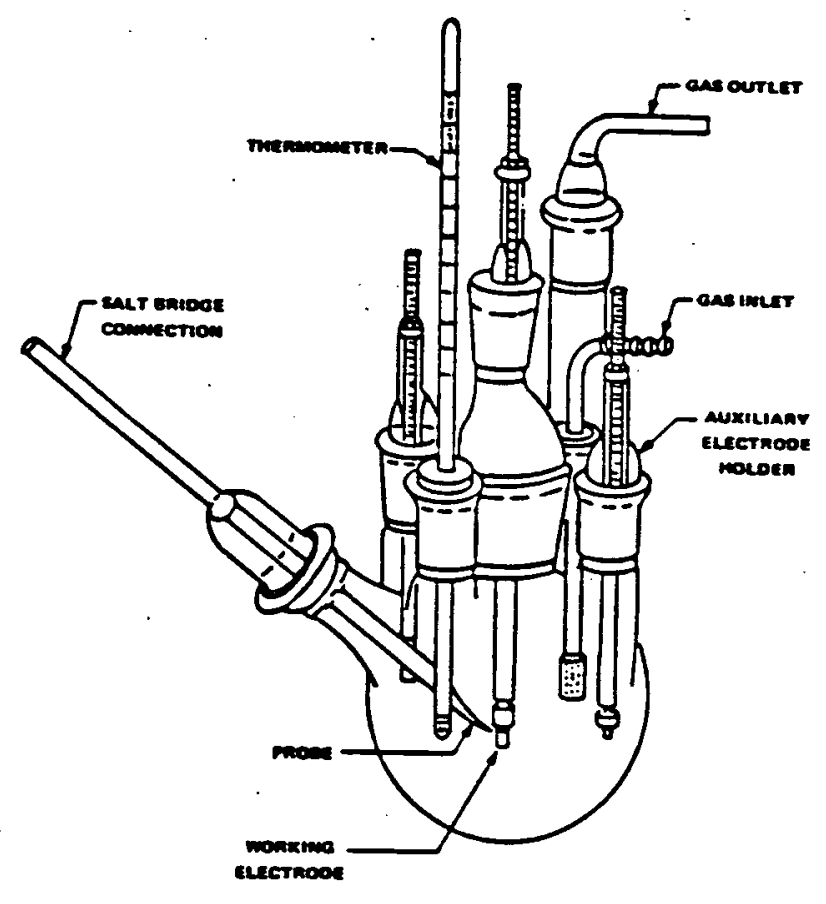

Fig.la. Standard Test Cell. 


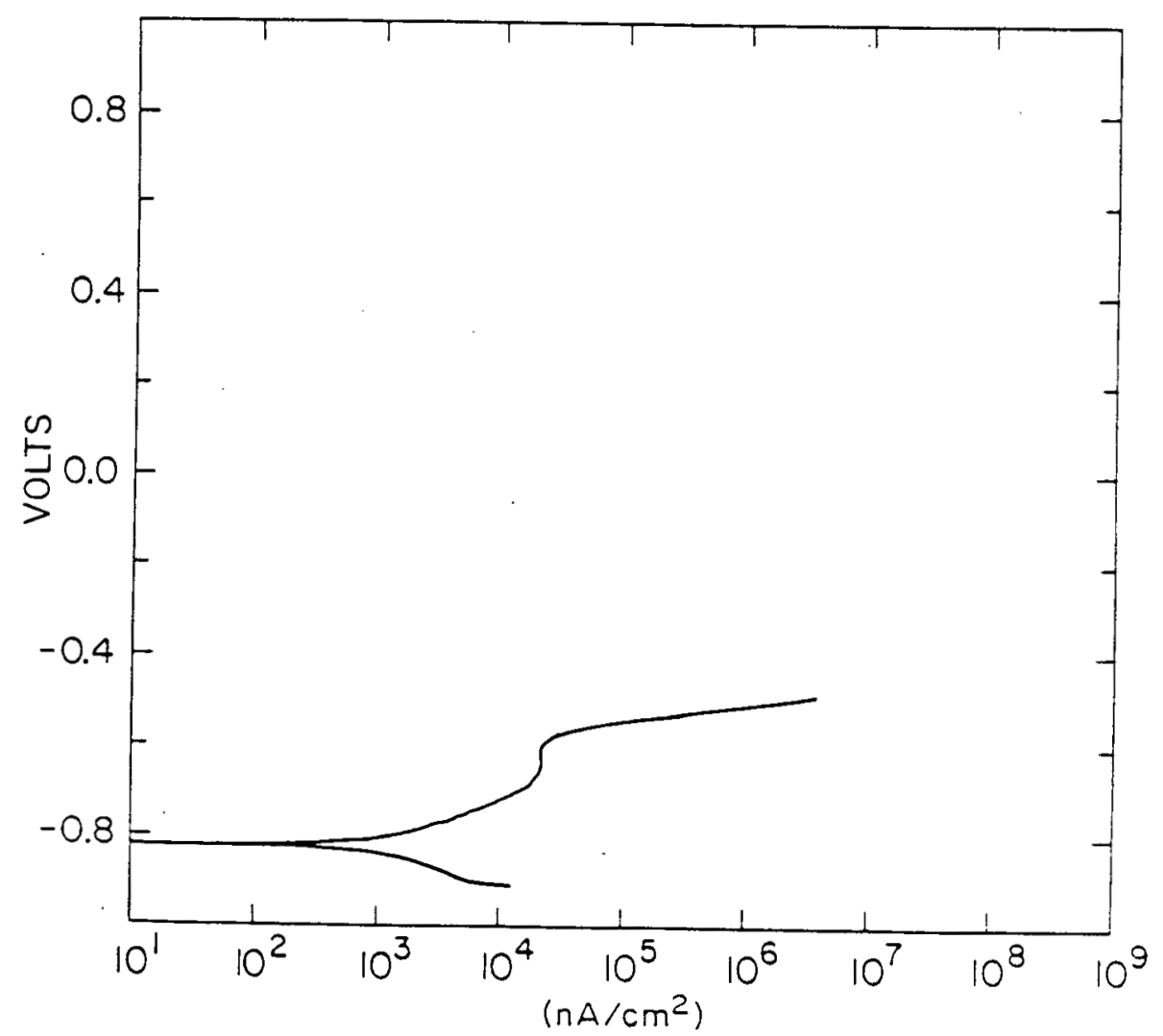

Figure 1. A285 steel in $1 \mathrm{~N} \mathrm{NaCl}$ at $22-25^{\circ} \mathrm{C}$. 


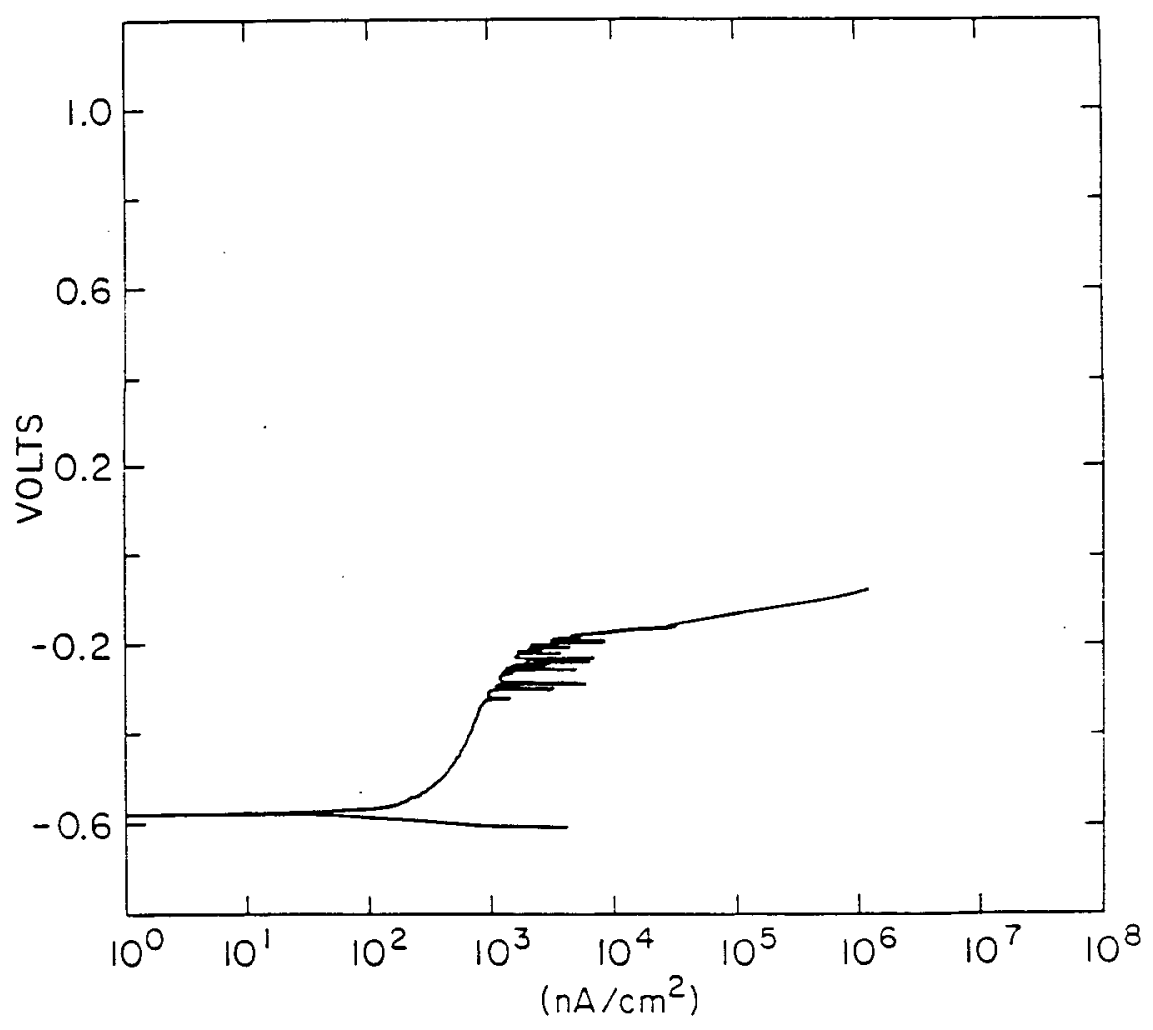

Figure 2. 410 Stainless Steel in $1 \mathrm{~N} \mathrm{NaCl}$ at $22 \cdot 25^{\circ} \mathrm{C}$. 


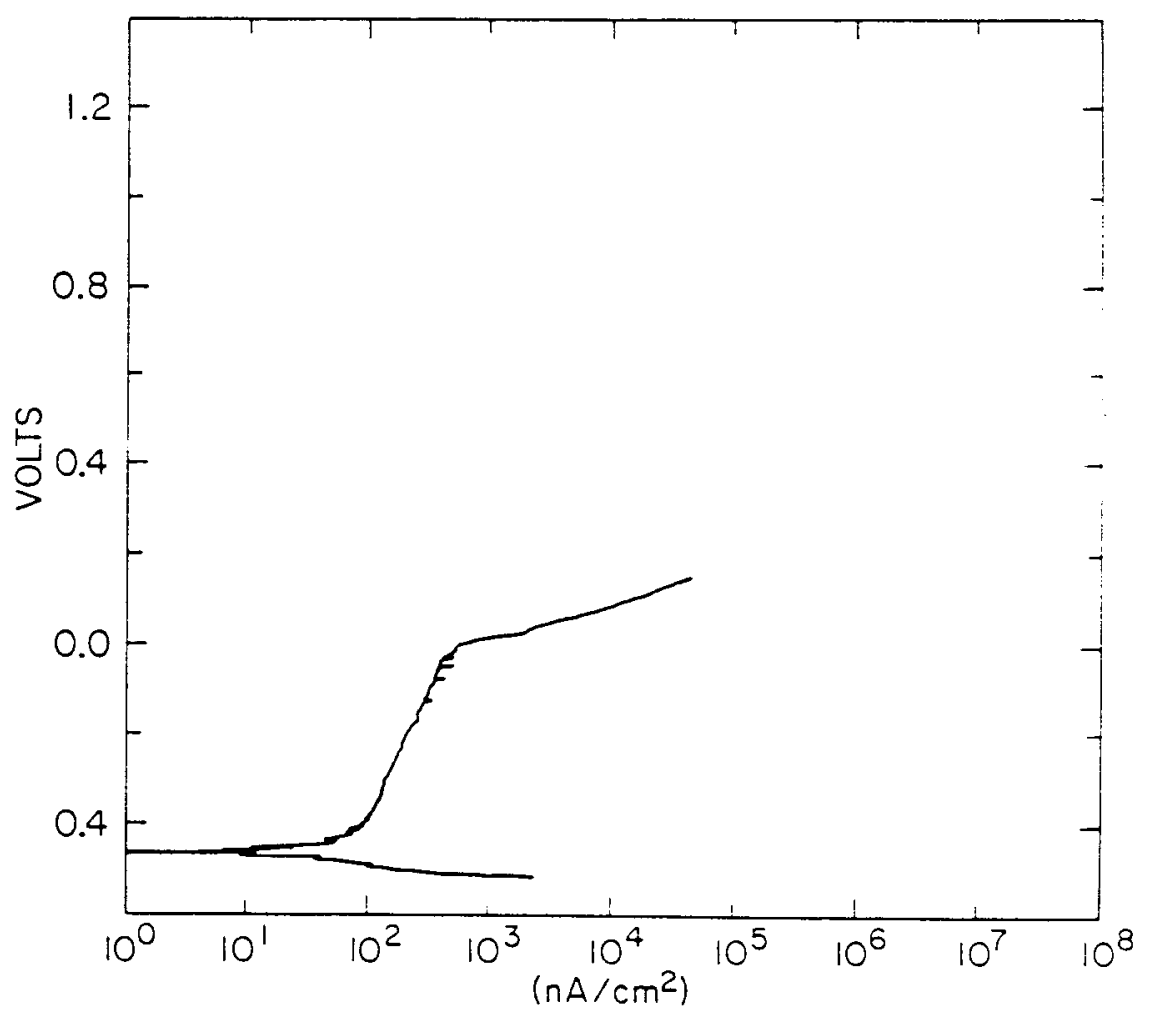

Figure 3. Alloy $2 \mathrm{RE} 60$ in $1 \mathrm{~N} \mathrm{NaCl}$ at $22 \cdot 25^{\circ} \mathrm{C}$. 


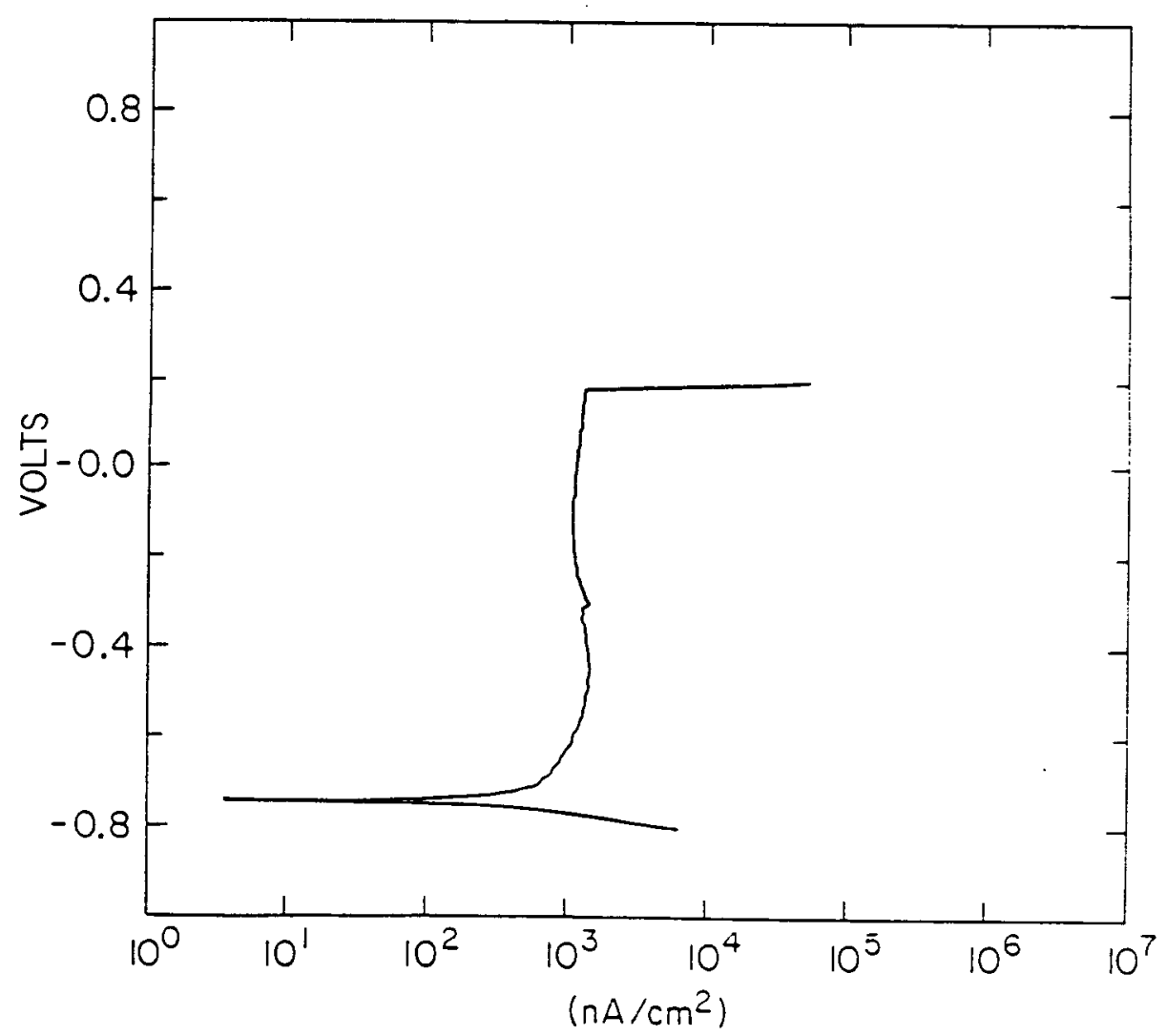

Figure 4. 304 Stainless Steel in $1 \mathrm{~N} \mathrm{NaCl}$ at $22-25^{\circ} \mathrm{C}$. 


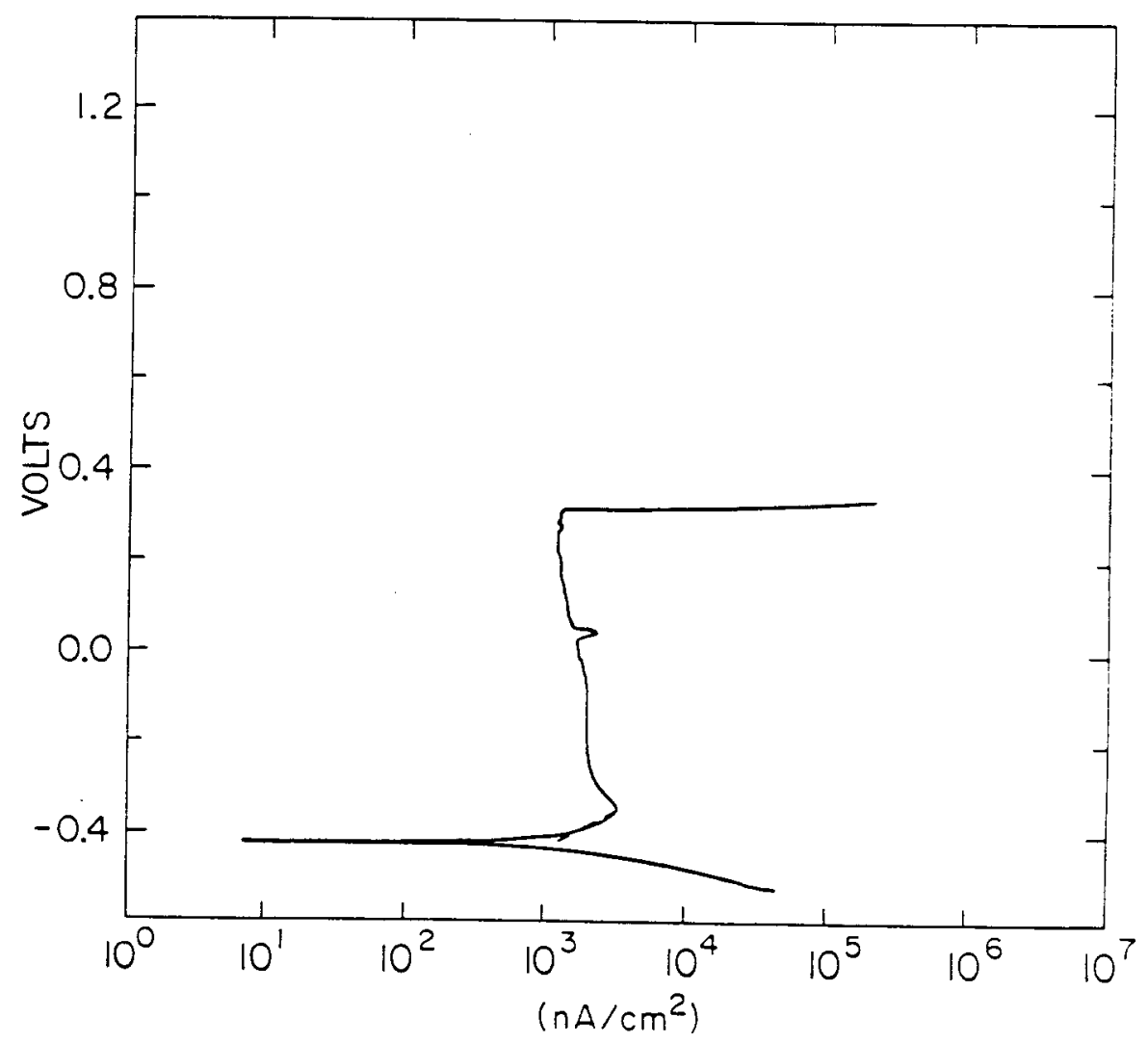

Figure 5. 316 Stainless Steel in $1 \mathrm{~N} \mathrm{NaCl}$ at $22 \cdot 25^{\circ} \mathrm{C}$. 


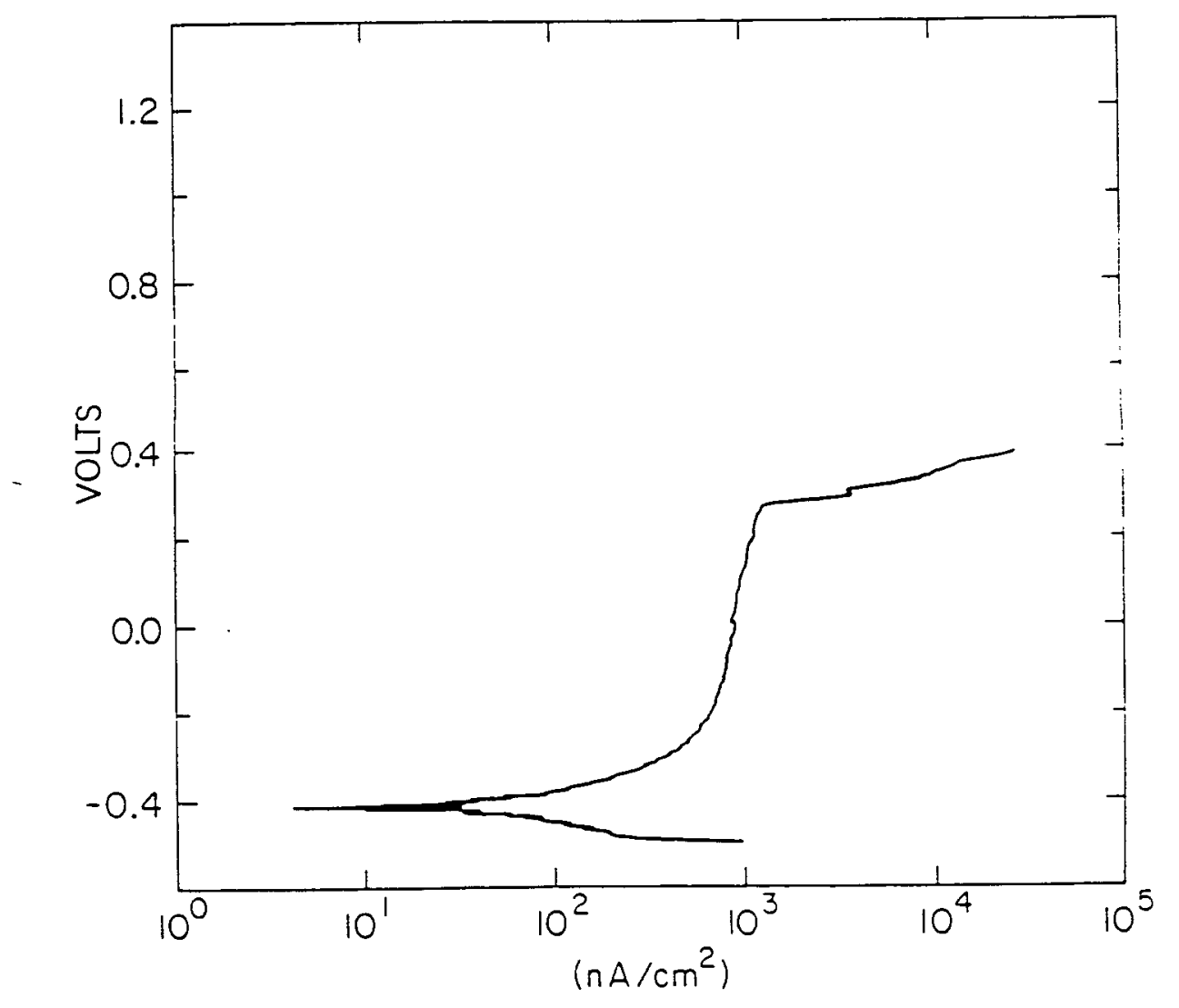

Figure 6. Alloy 825 in $1 \mathrm{~N} \mathrm{NaCl}$ at $22-25^{\circ} \mathrm{C}$. 


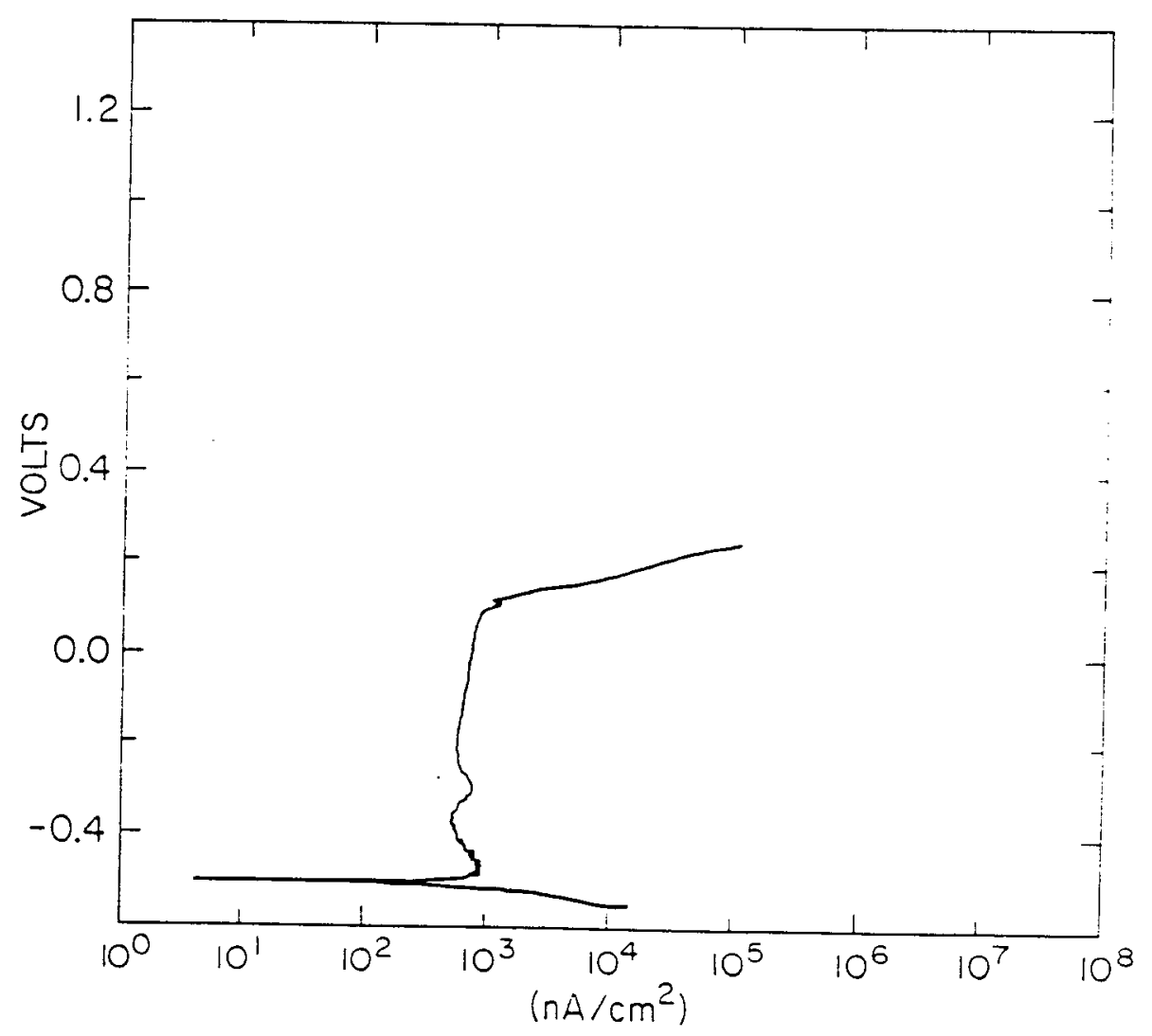

Figure 7. Carpenter $20 \mathrm{Cb}-3$ in $1 \mathrm{~N} \mathrm{NaCl}$ at $22 \cdot 25^{\circ} \mathrm{C}$. 


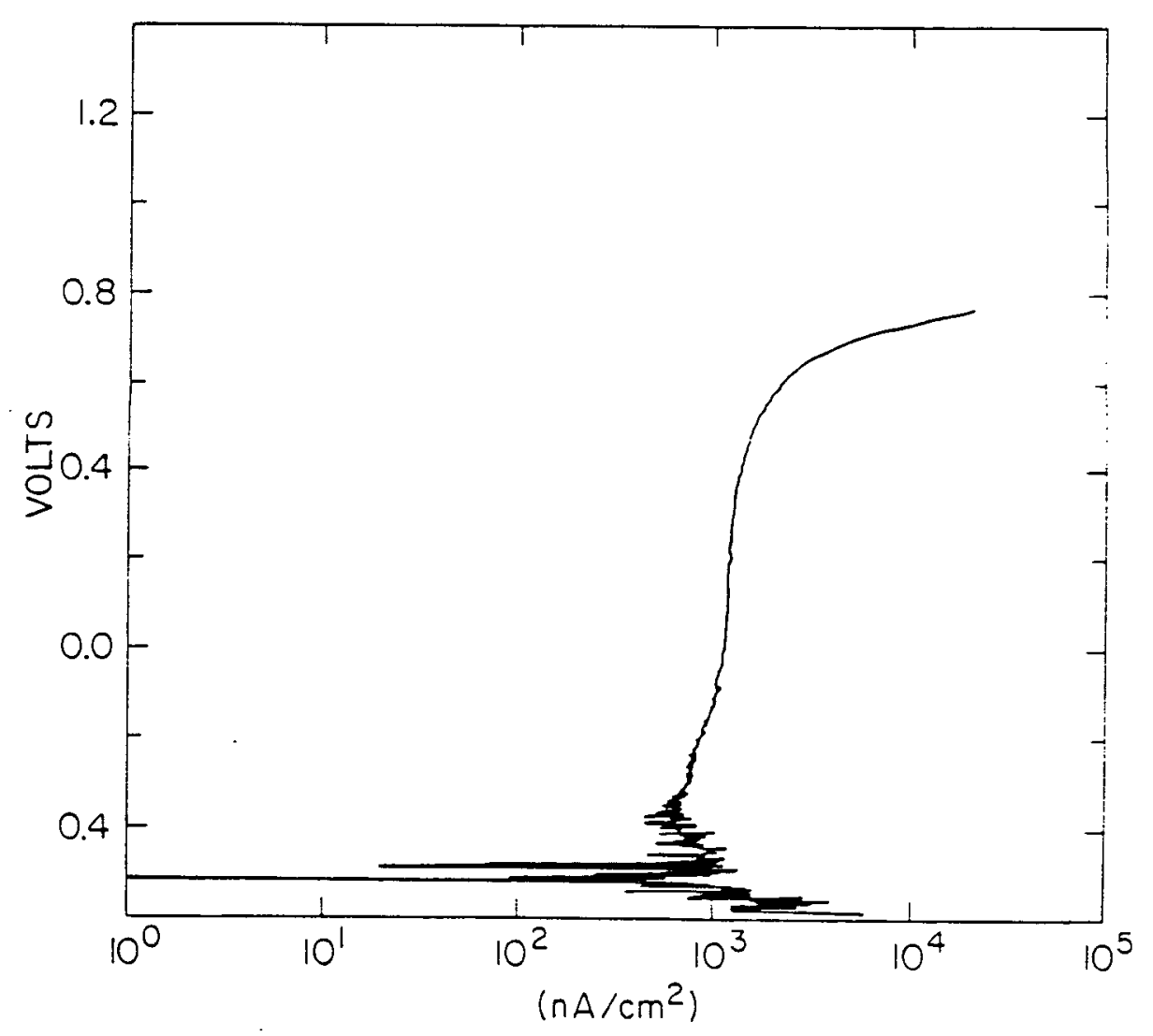

Figure 8. Hastelloy $\mathrm{G}$ in $\mathrm{IN} \mathrm{NaCl}$ at $22-25^{\circ} \mathrm{C}$. 


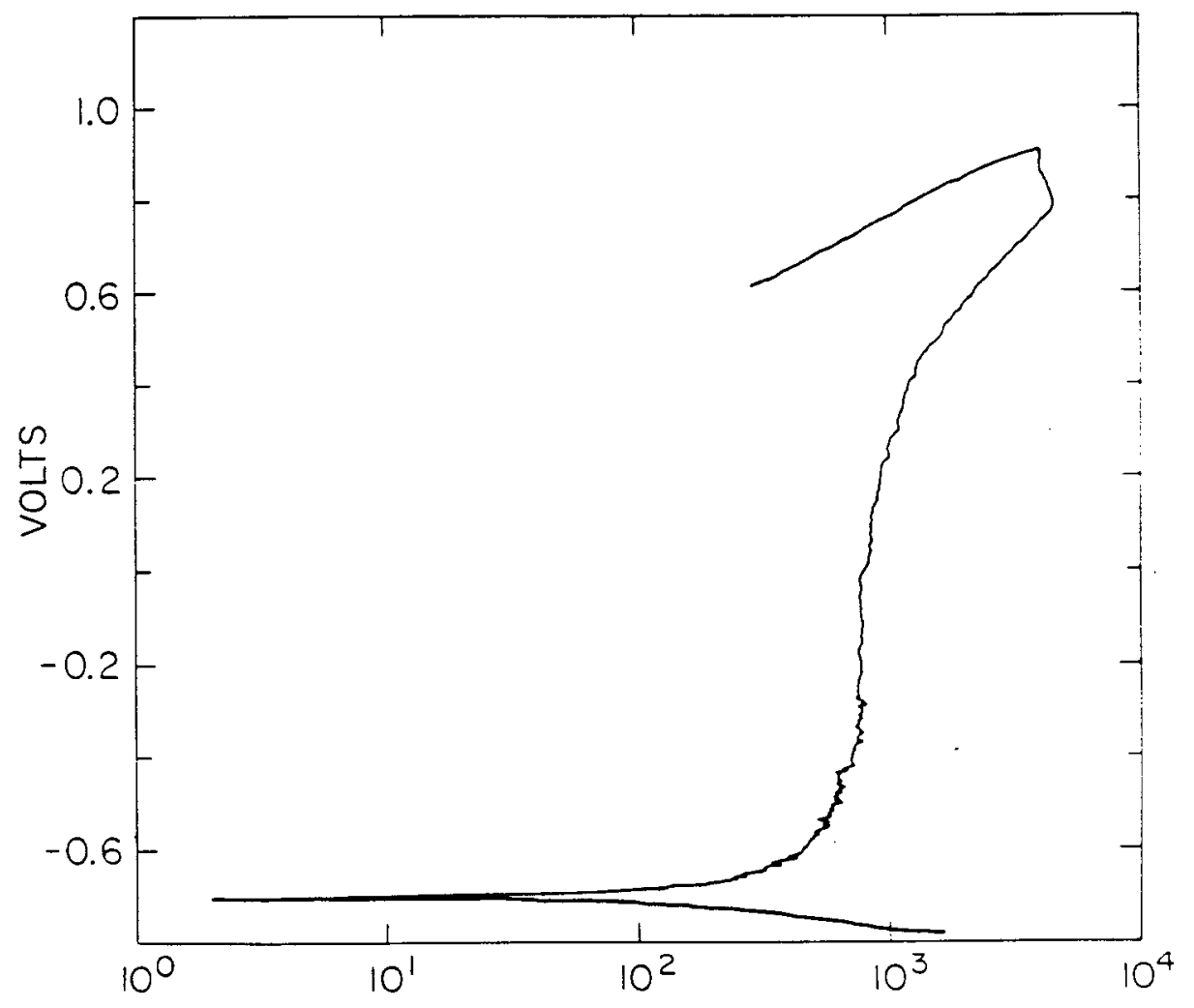

Figure 9. 29-4 Cr-Mo Stainless Steel in $1 \mathrm{~N} \mathrm{NaCl}$ at $22-25^{\circ} \mathrm{C}$. 


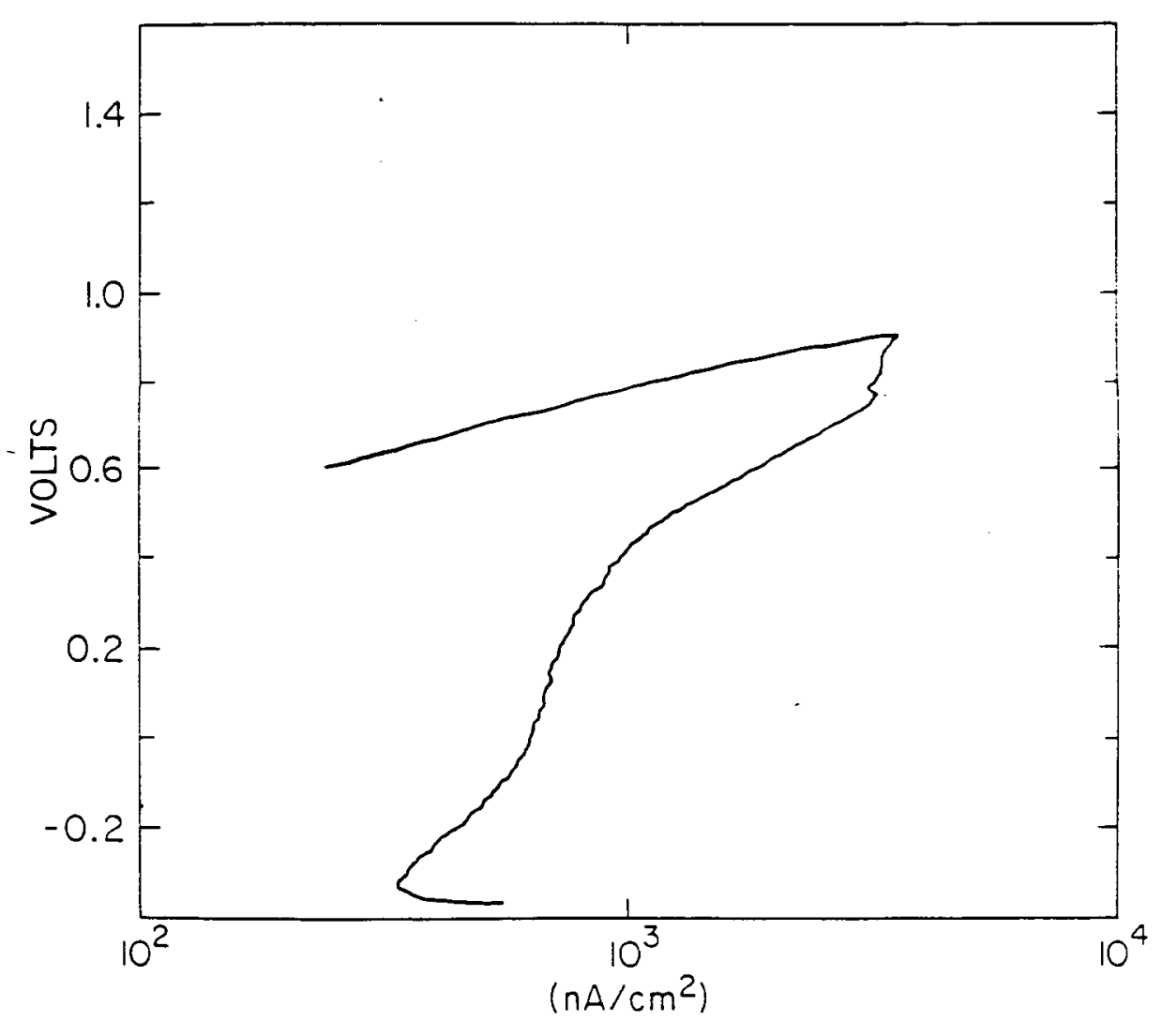

Figure 10. Stainless Steel AL-6X in IN NaCl at $22-25^{\circ} \mathrm{C}$. 


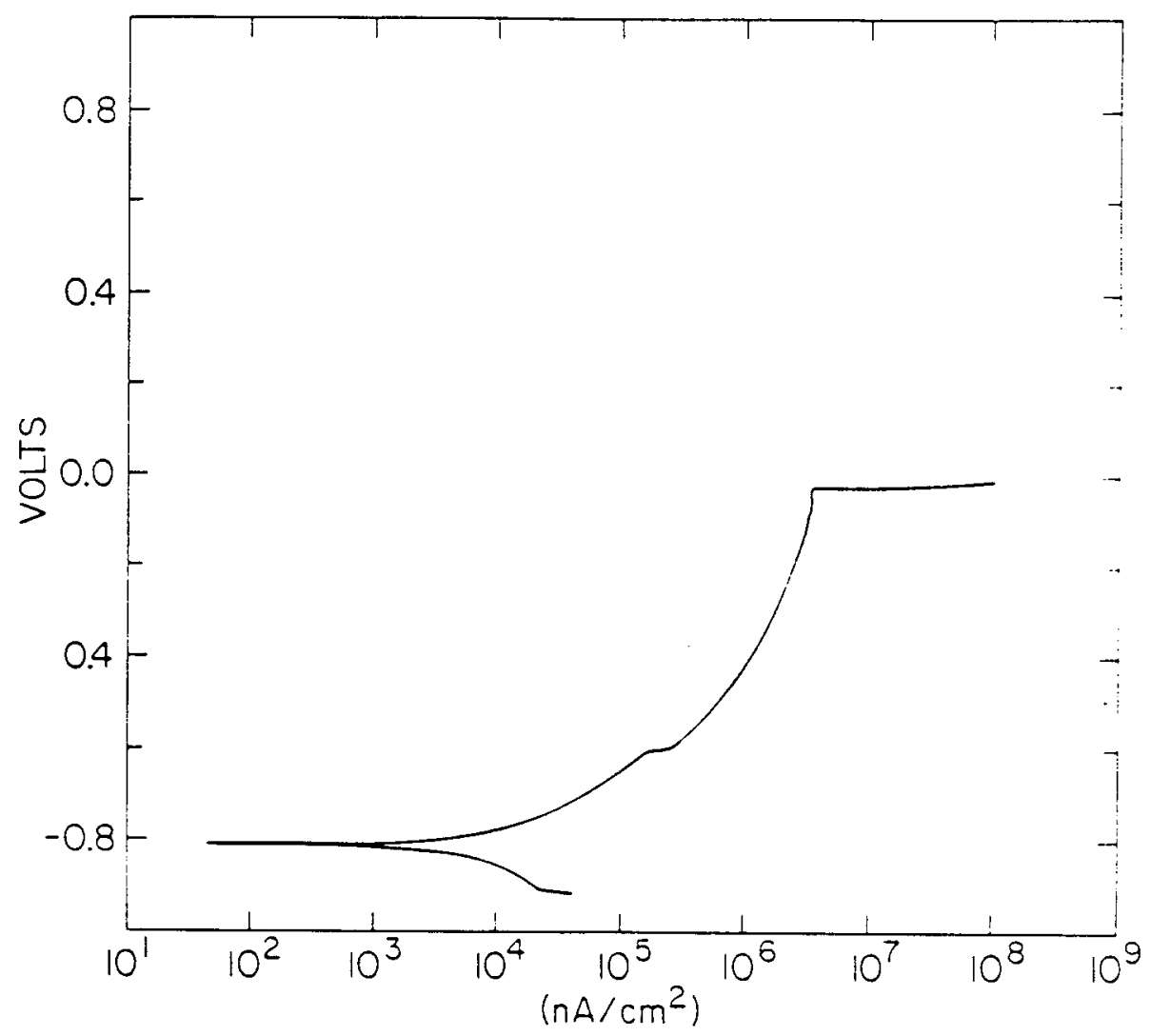

Figure 11. A285 steel in $1 \mathrm{~N} \mathrm{NaCl}$ at $50^{\circ} \mathrm{C}$. 


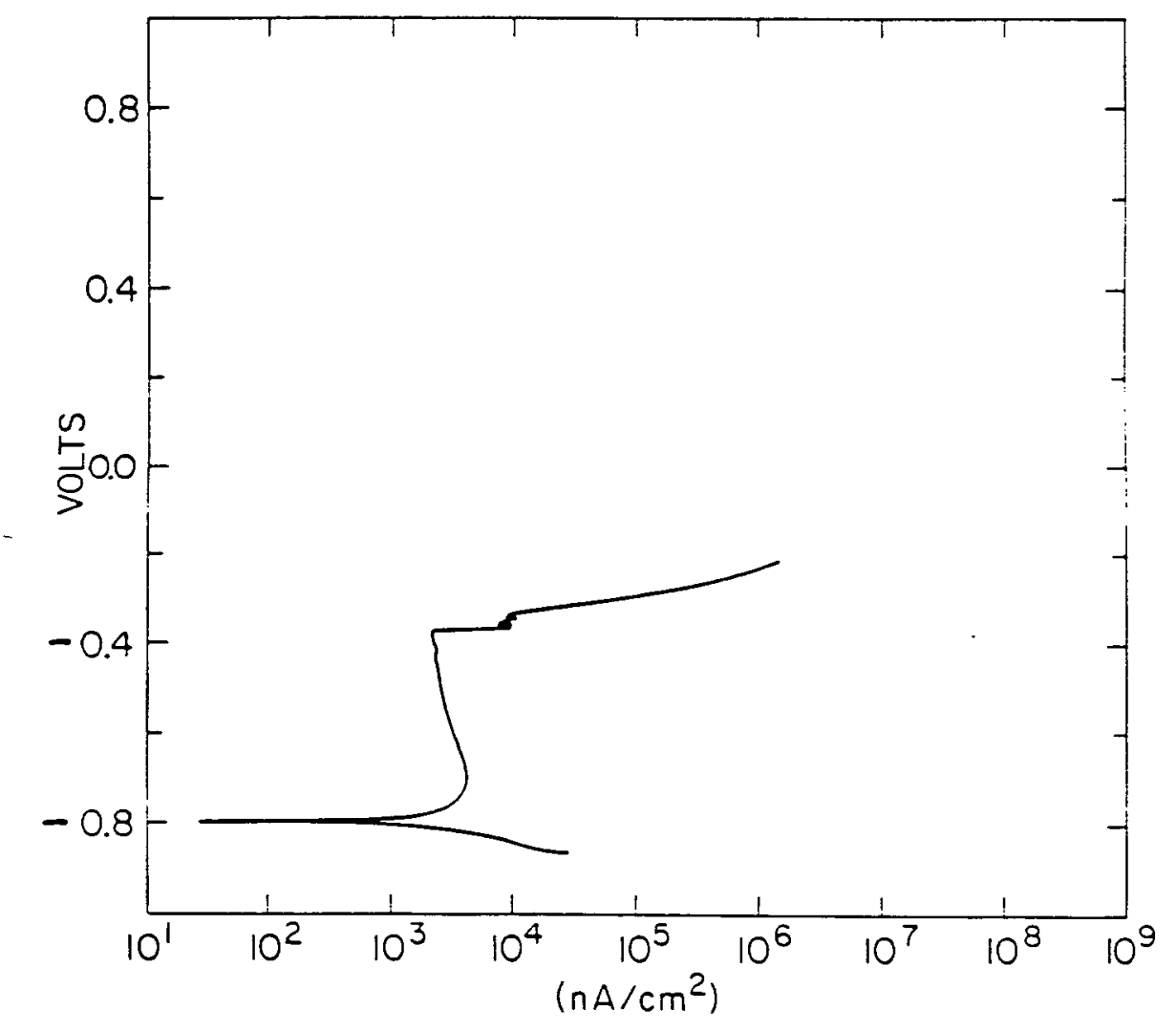

Figure 12. 410 Stainless Steel in $1 \mathrm{~N} \mathrm{NaCl}$ at $50^{\circ} \mathrm{C}$. 


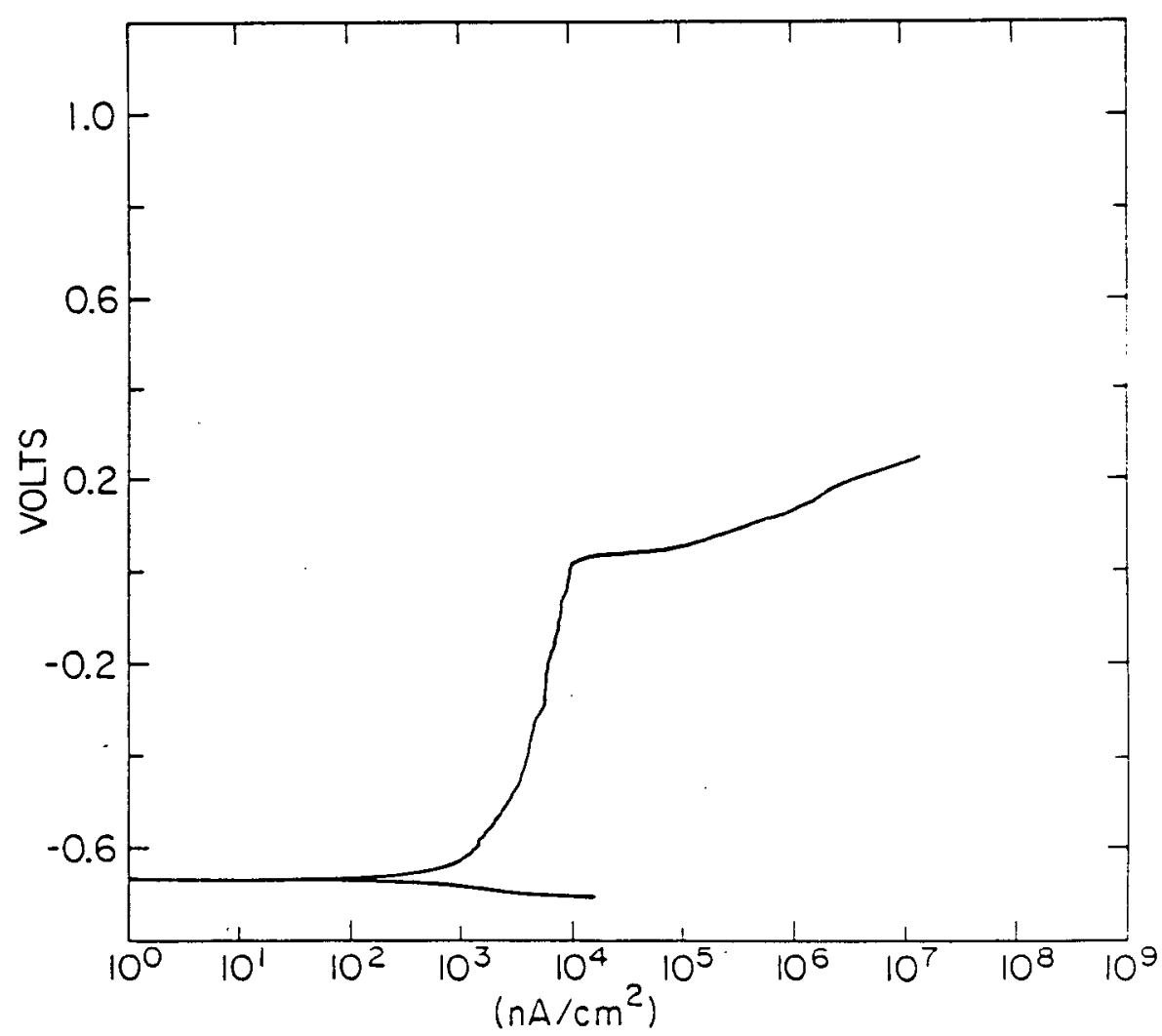

Figure 13. 2RE60 Stainless Steel in $1 \mathrm{~N} \mathrm{NaCl}$ at $50^{\circ} \mathrm{C}$. 


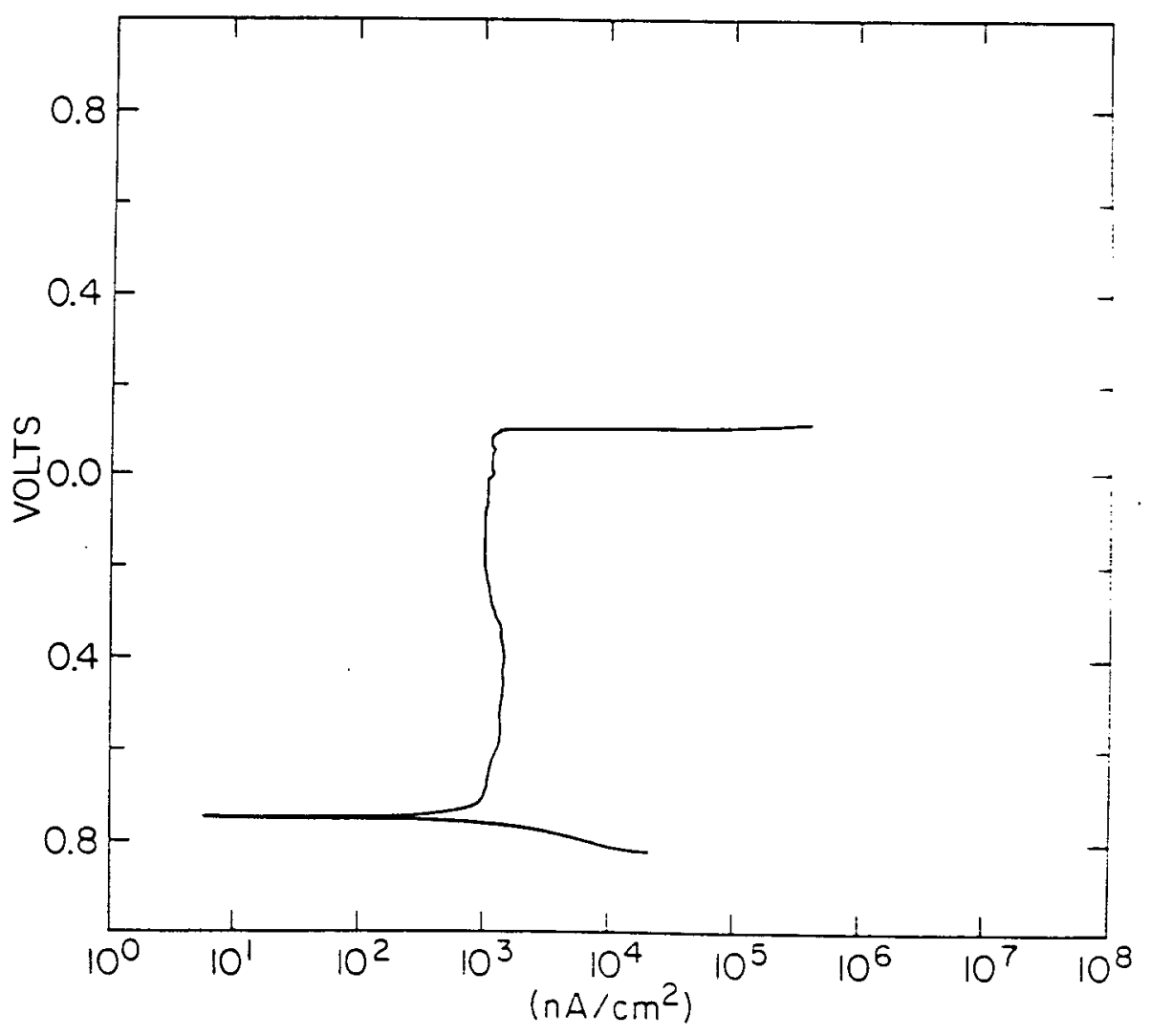

Figure 14. 304 Stainless steel in $1 \mathrm{~N} \mathrm{NaCl}$ at $50^{\circ} \mathrm{C}$. 


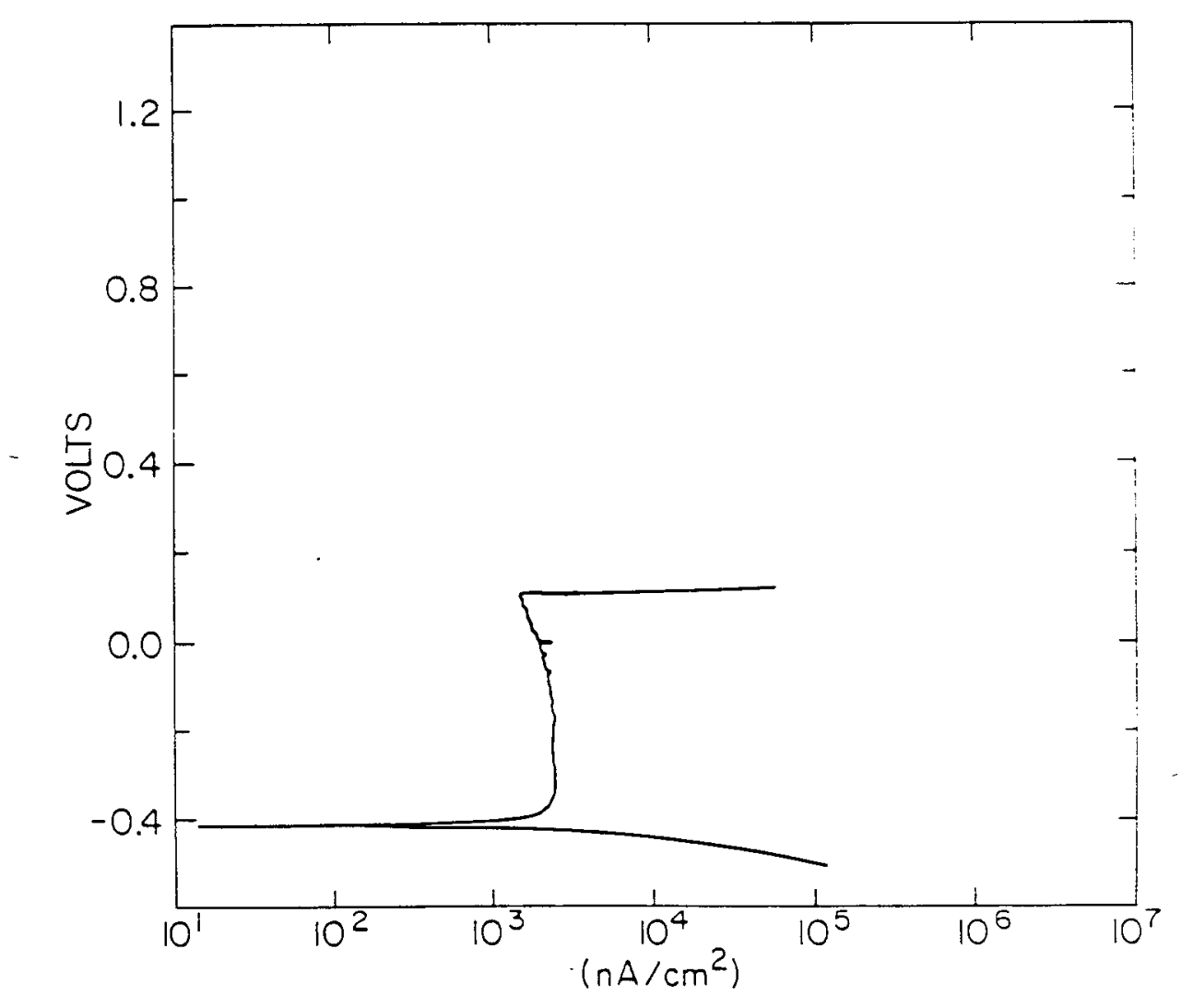

Figure 15. 316 Stainless steel in $1 \mathrm{~N} \mathrm{NaCl}$ at $50^{\circ} \mathrm{C}$. 


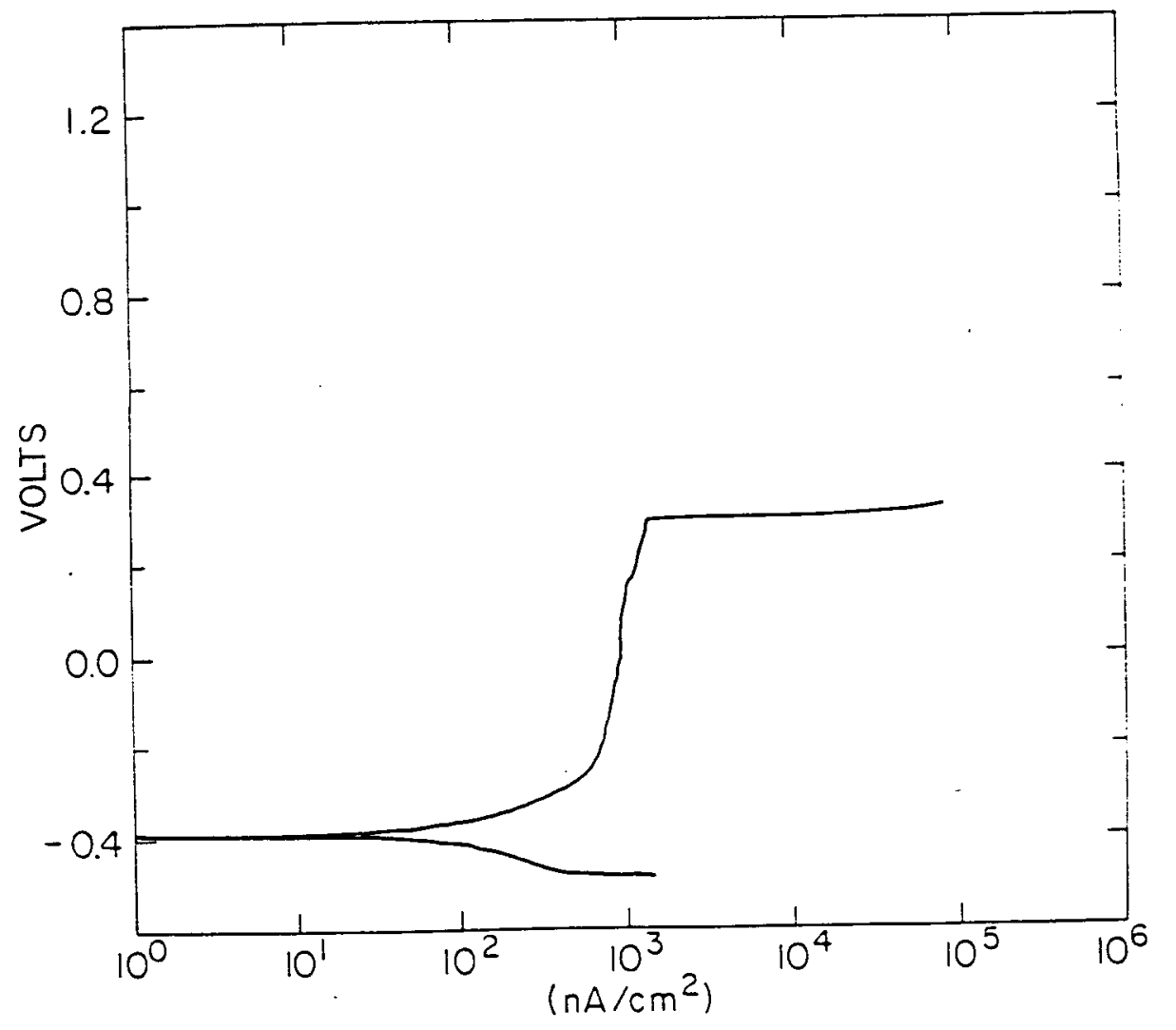

Figure 16. 825 Stainless Alloy in $1 \mathrm{~N} \mathrm{NaCl}$ at $50^{\circ} \mathrm{C}$. 


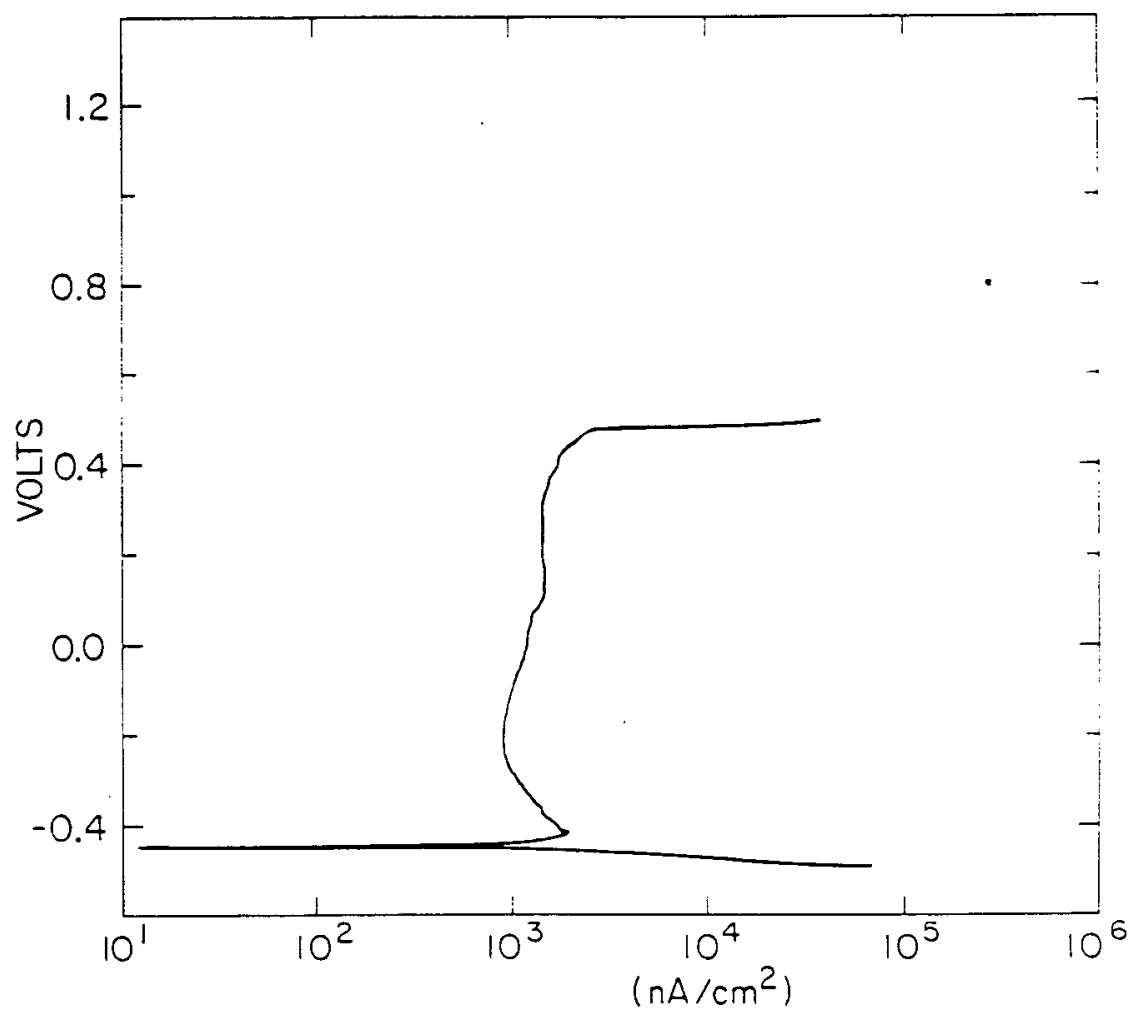

Figure 17. Hastelloy $\mathrm{G}$ in $1 \mathrm{~N} \mathrm{NaCl}$ at $50^{\circ} \mathrm{C}$. 


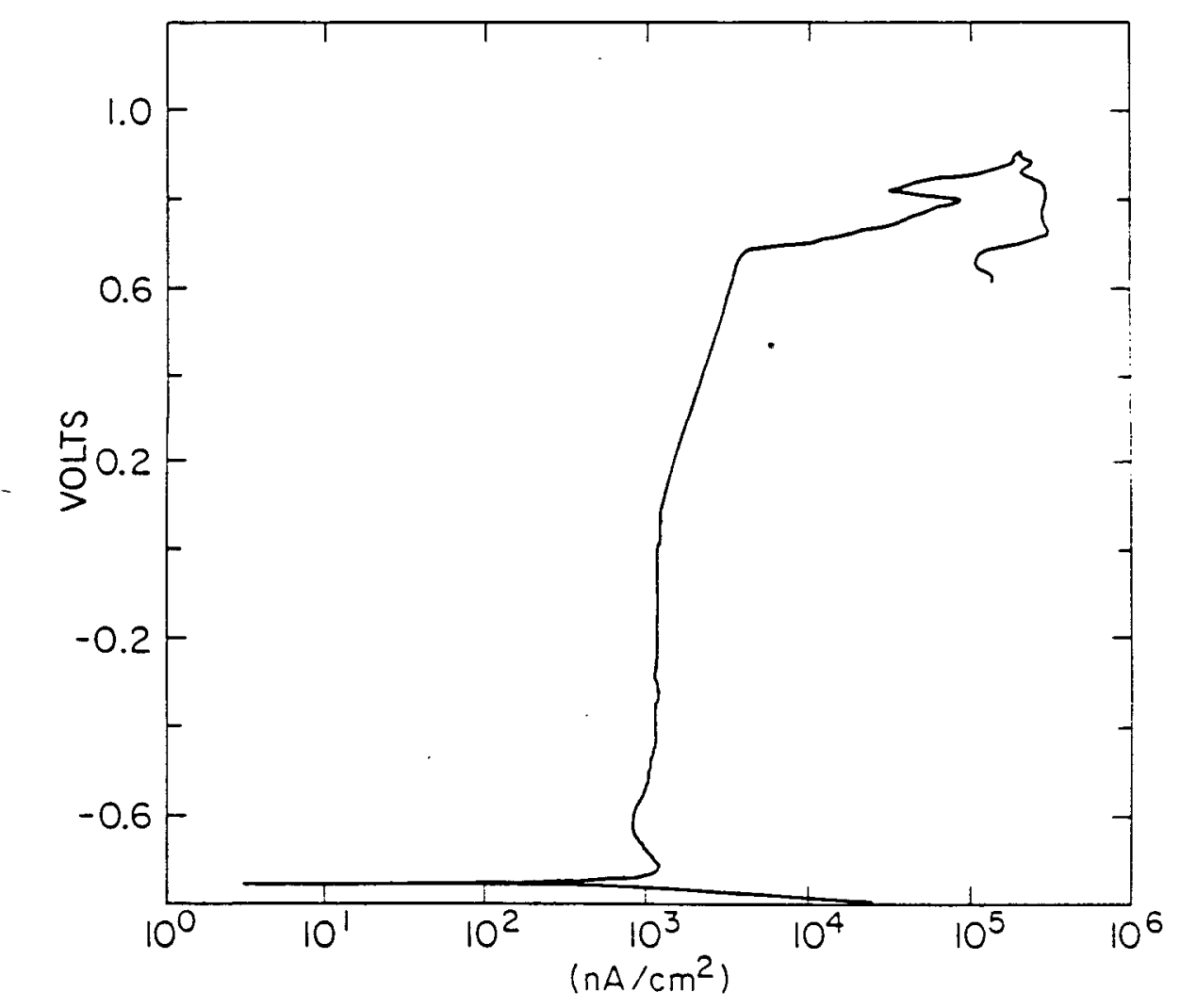

Figure 18. AL-6X Stainless Steel in $1 \mathrm{~N} \mathrm{NaCl}$ at $50^{\circ} \mathrm{C}$. 


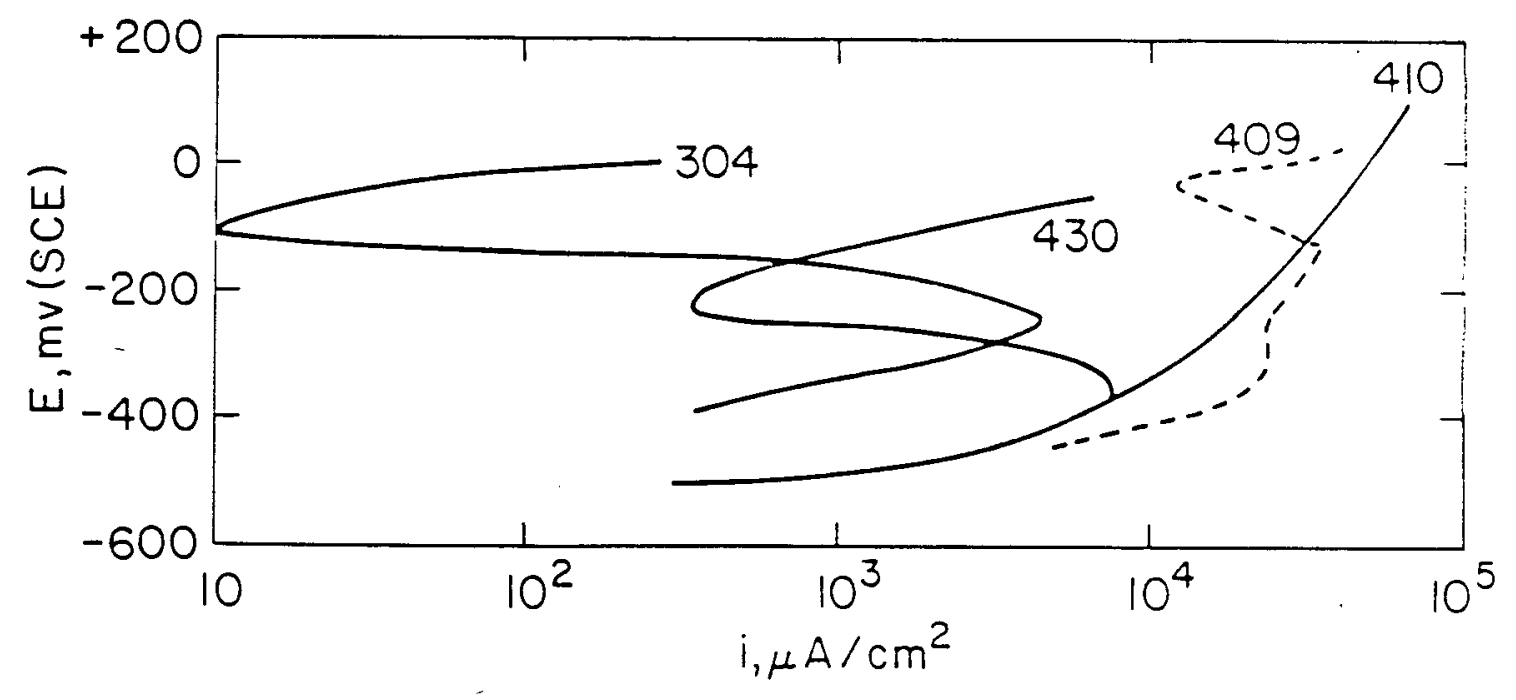

Figure 19. 304, 430, 409, 410 Stainless

Steel in $1 \mathrm{~N} \mathrm{NaCl}+1 \mathrm{~N}_{2} \mathrm{SO}_{4}$ at $22-25^{\circ} \mathrm{C}$. 


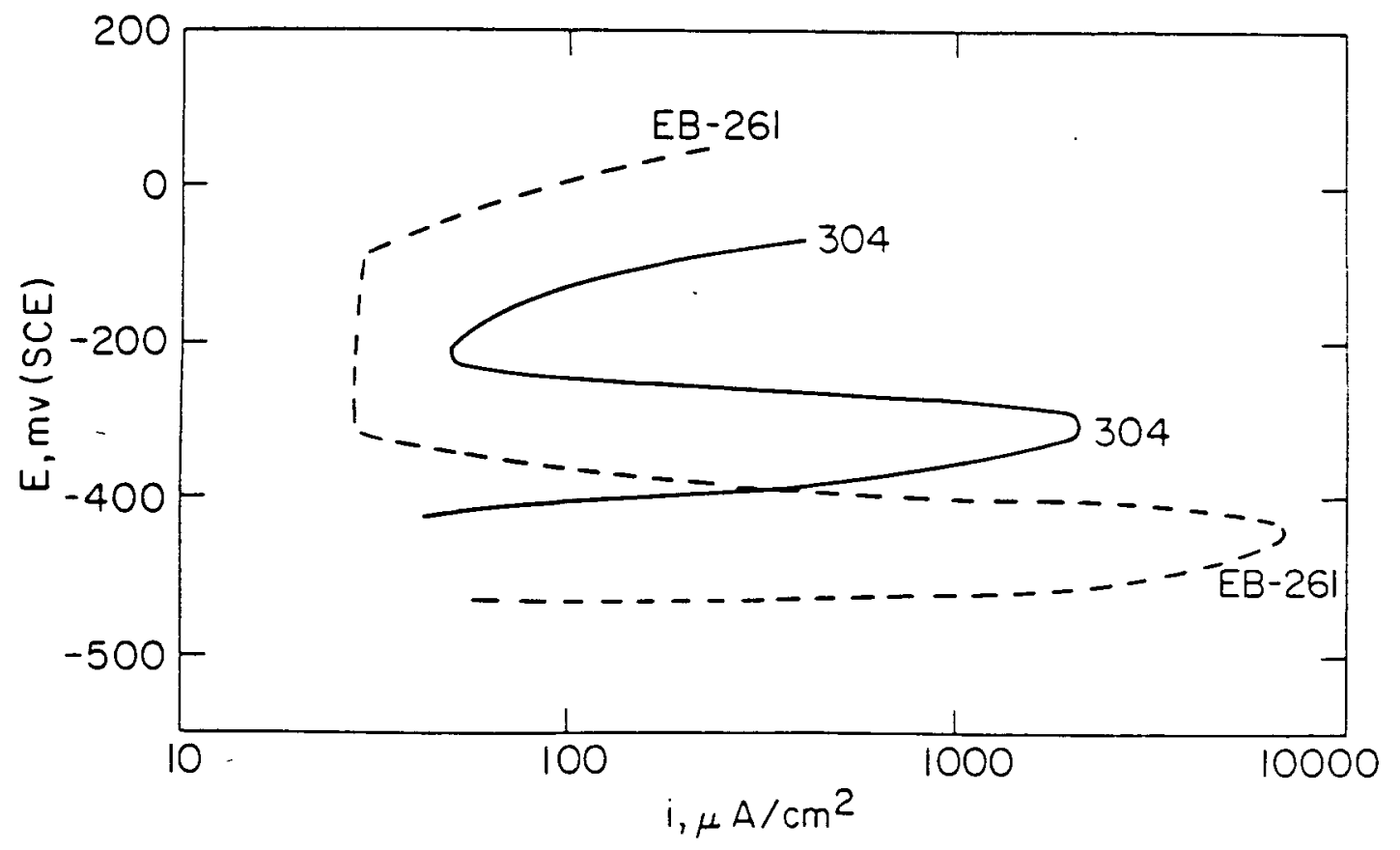

Figure 20. 304 Stainless Steel and E-Brite $26-1$ in $0.25 \mathrm{~N} \mathrm{HCl}$ at $40^{\circ} \mathrm{C}$. 


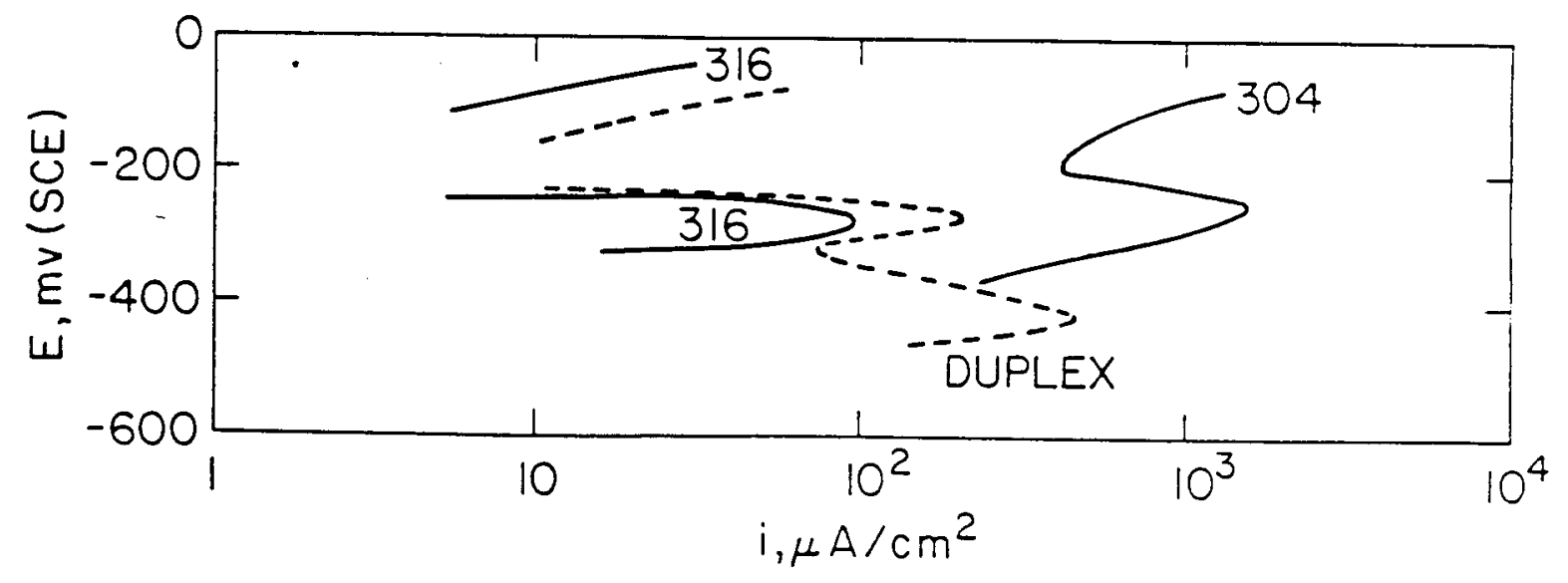

Figure 21. 304, 316 and Duplex Stainless steel in $0.3 \mathrm{~N} \mathrm{HCl}$ at $40^{\circ} \mathrm{C}$. 


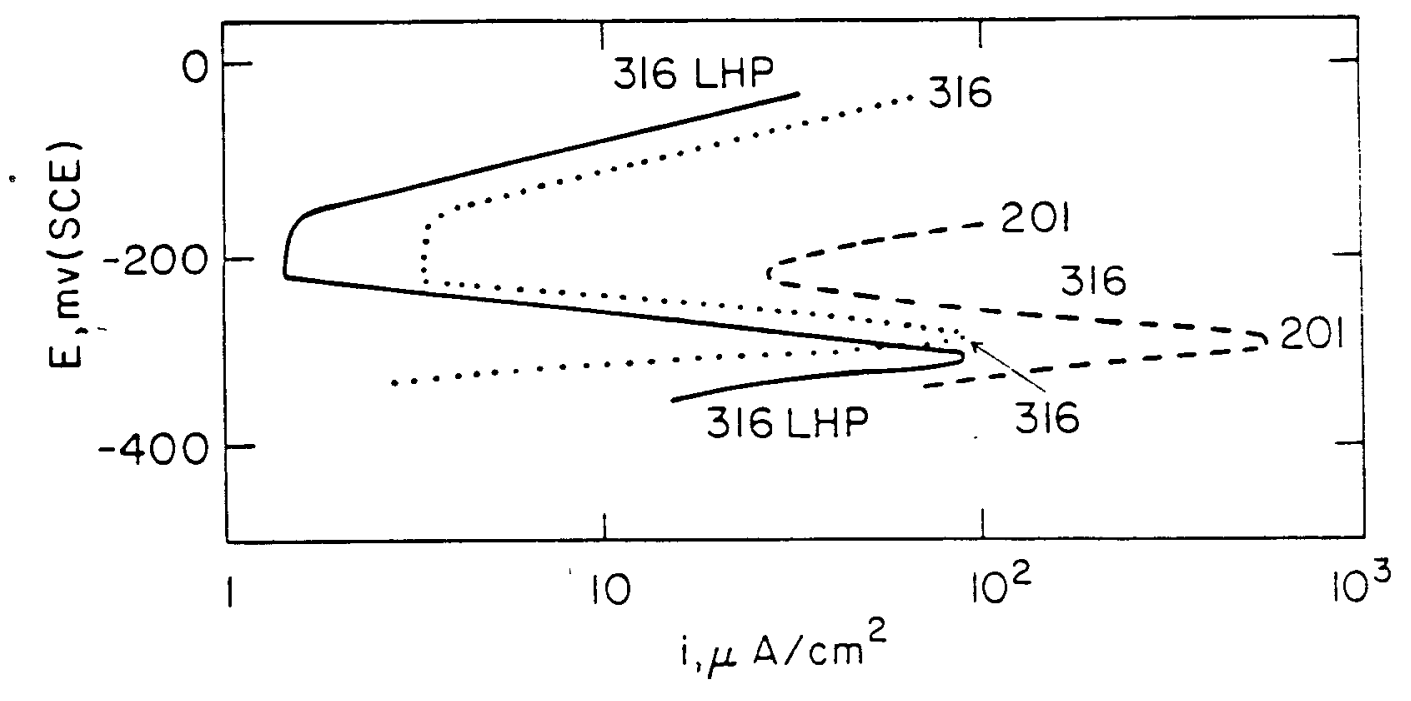

Figure 22. 201,316 and 316 LHP stainless steel in $0.3 \mathrm{~N} \mathrm{HCl}$ at $40^{\circ} \mathrm{C}$. 


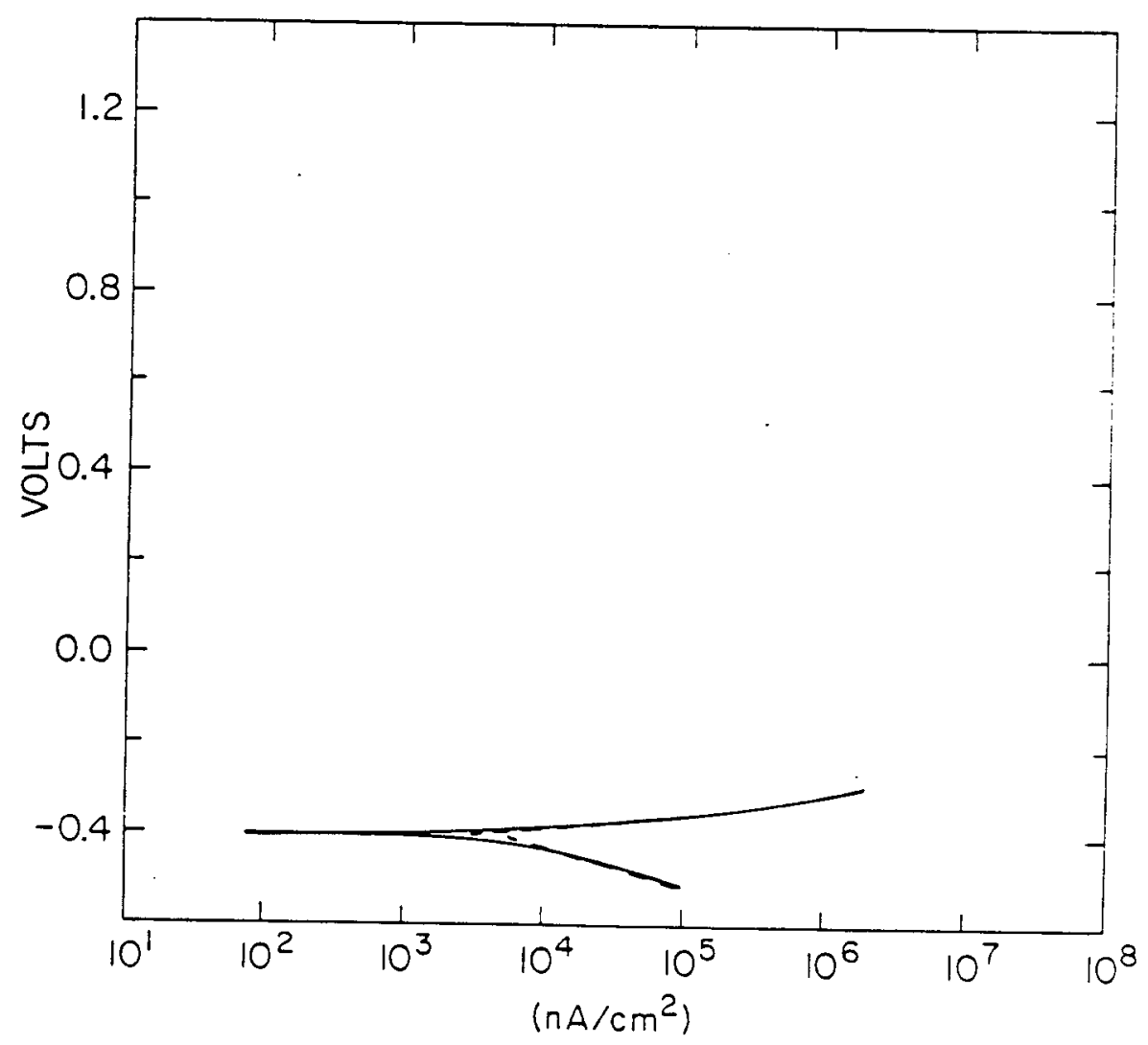

Figure 23. $17-4 \mathrm{PH}$ Stainless steel in $0.5 \mathrm{~N} \mathrm{HCl}+1 \mathrm{~N} \mathrm{NaCl}$ at $25^{\circ} \mathrm{C}$. 


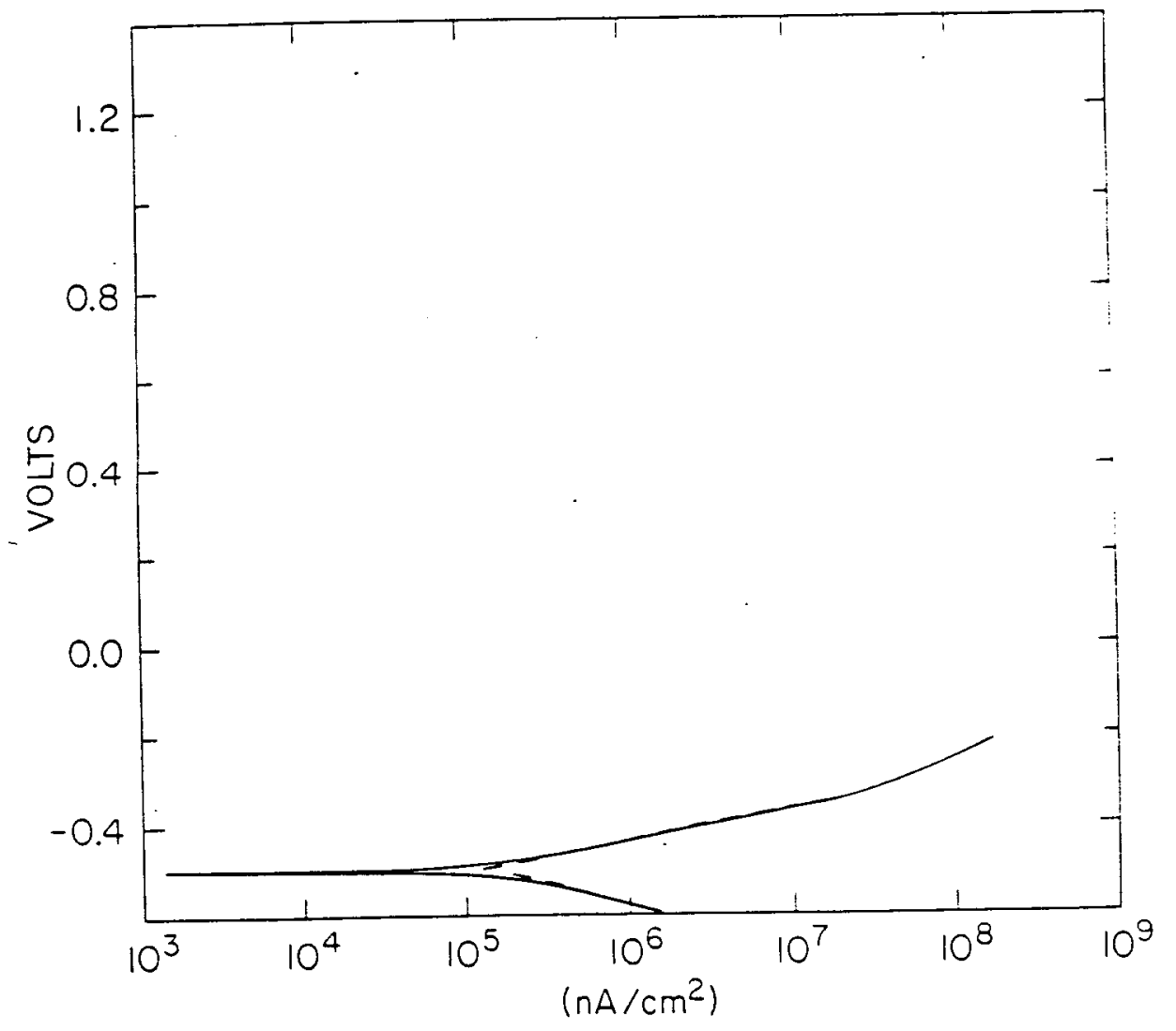

Figure 24. 410 Stainless steel in $0.5 \mathrm{~N} \mathrm{HCl}+1 \mathrm{~N} \mathrm{NaCl}$ at $25^{\circ} \mathrm{C}$. 


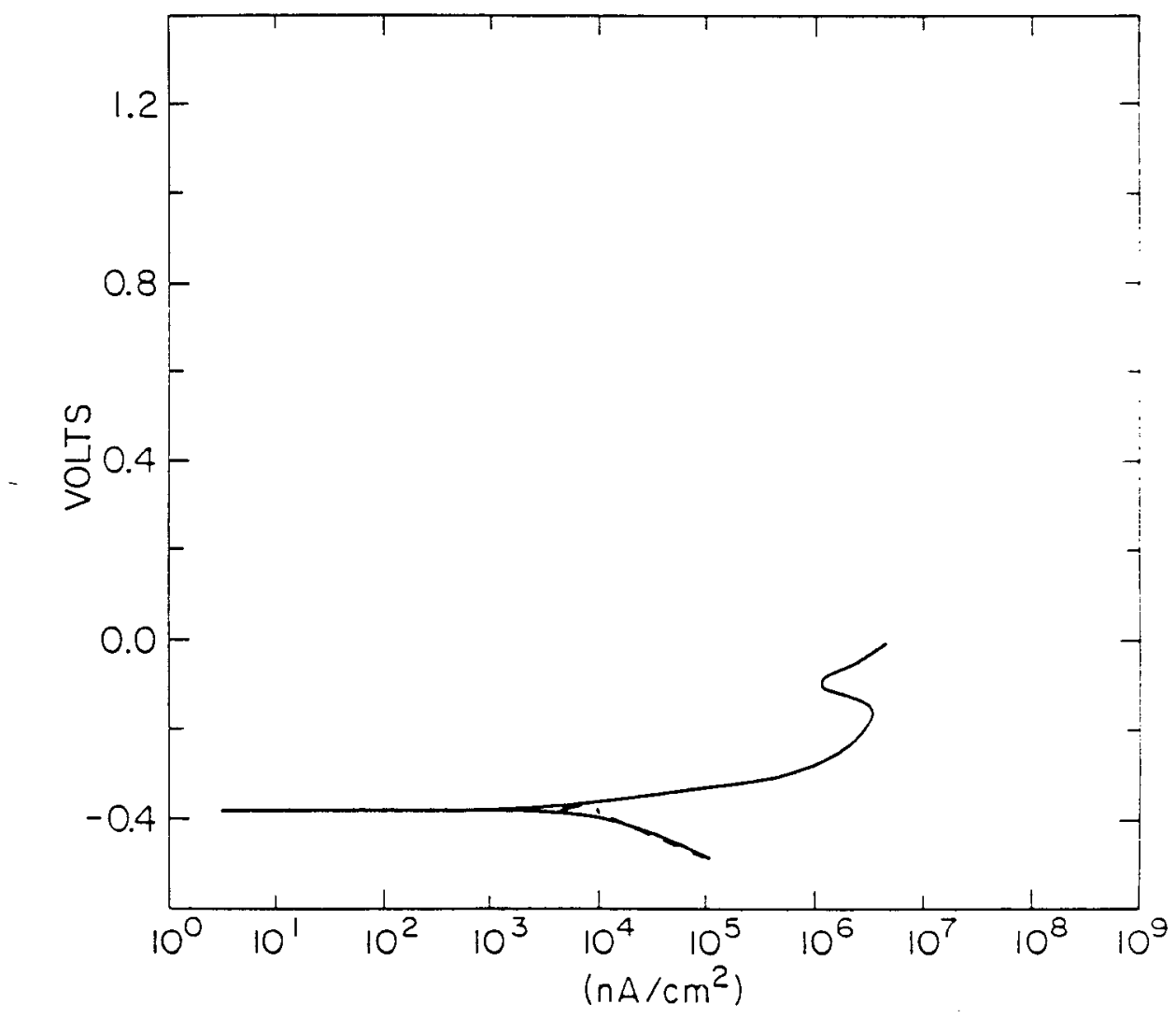

Figure 25. 304 Stainless Steel in $0.5 \mathrm{~N} \mathrm{HCl}+1 \mathrm{~N} \mathrm{NaCl}$ at $25^{\circ} \mathrm{C}$. 


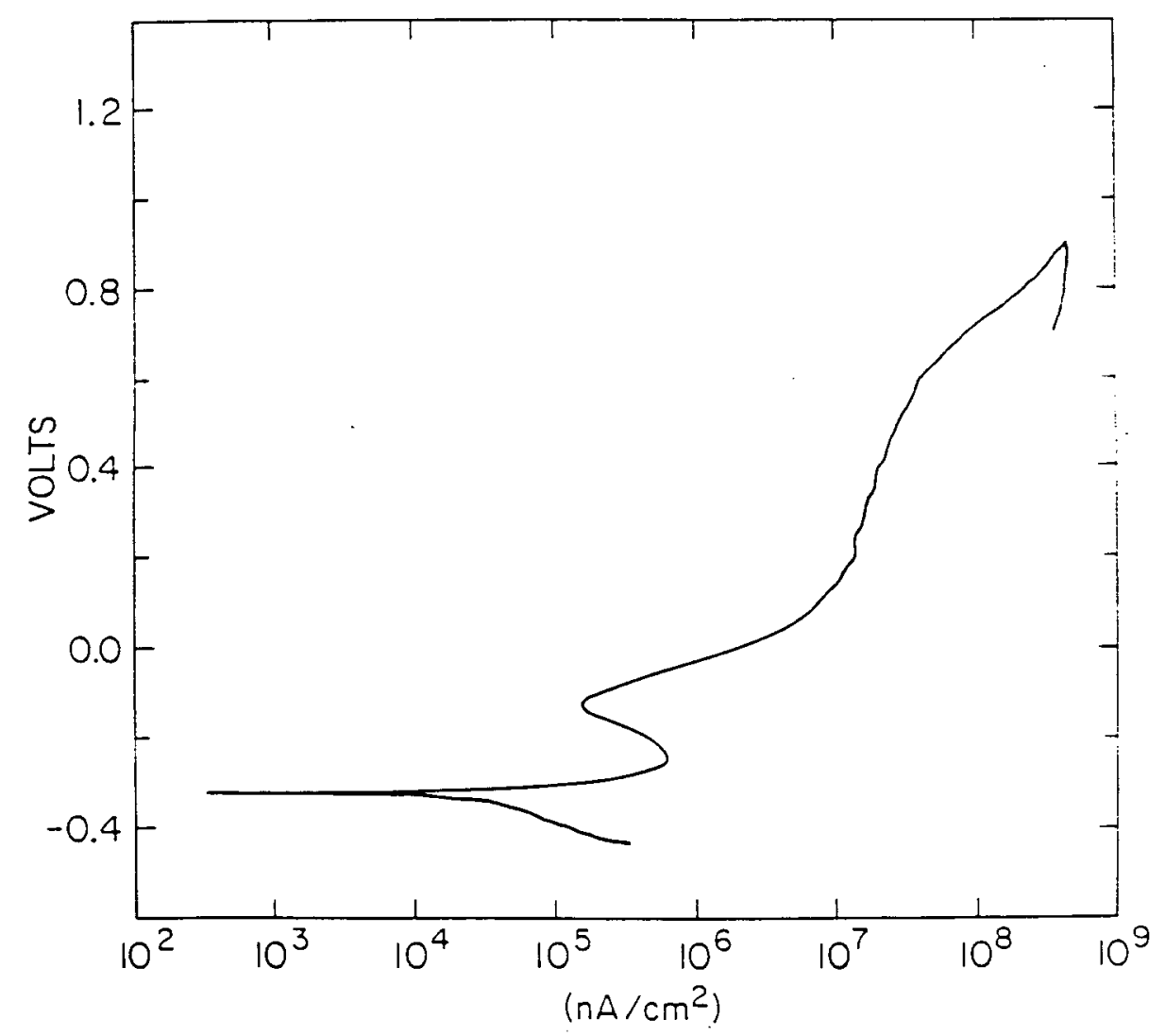

Figure 26. 316 Stainless steel in $0.5 \mathrm{~N} \mathrm{HCl}+1 \mathrm{~N} \mathrm{NaCl}$ at $25^{\circ} \mathrm{C}$. 


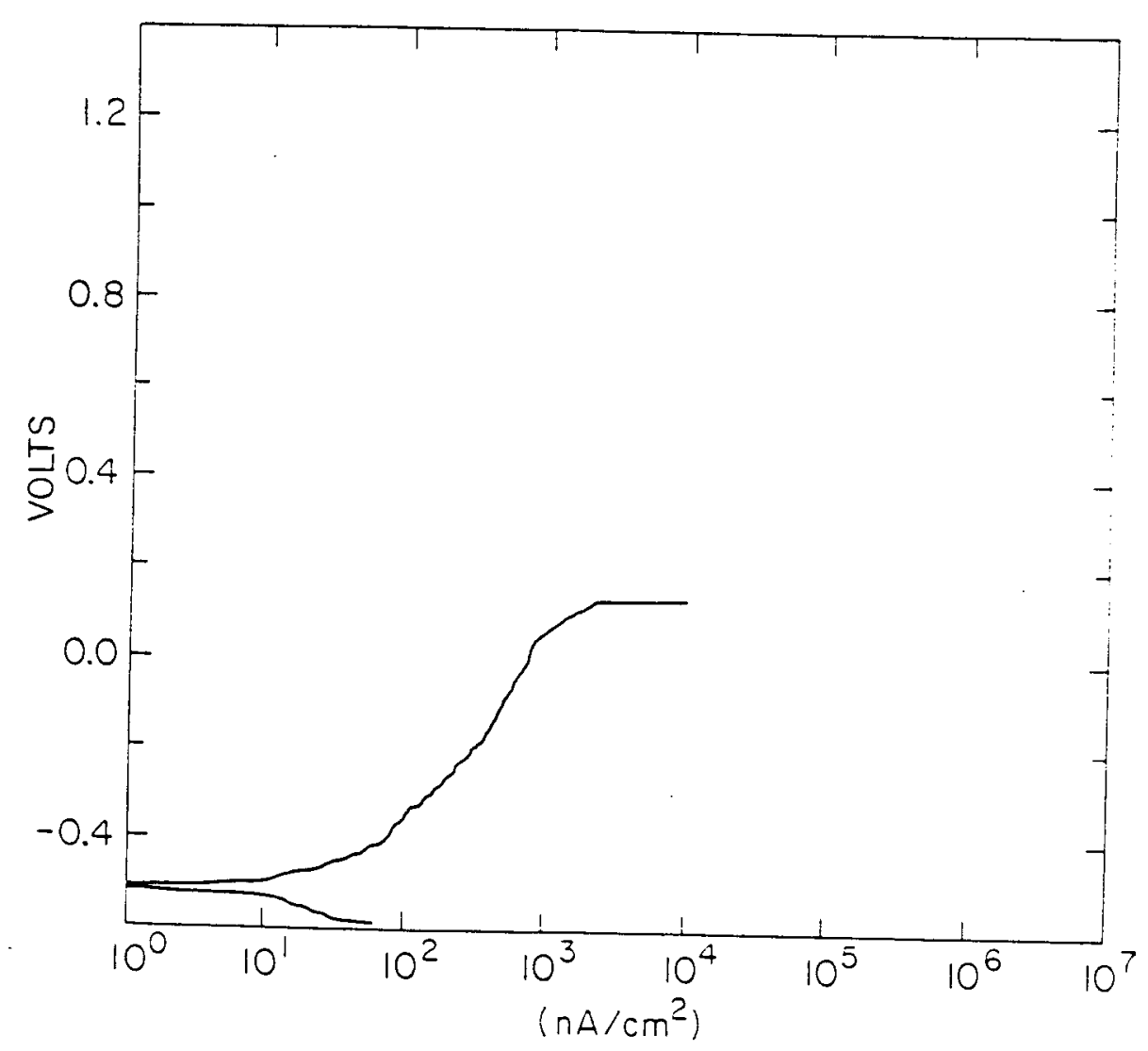

$\mathbf{I}$

Figure 27. 2RE60 stainless steel in $0.5 \mathrm{~N} \mathrm{HCl}+1 \mathrm{~N} \mathrm{NaCl}$ at $25^{\circ} \mathrm{C}$. 


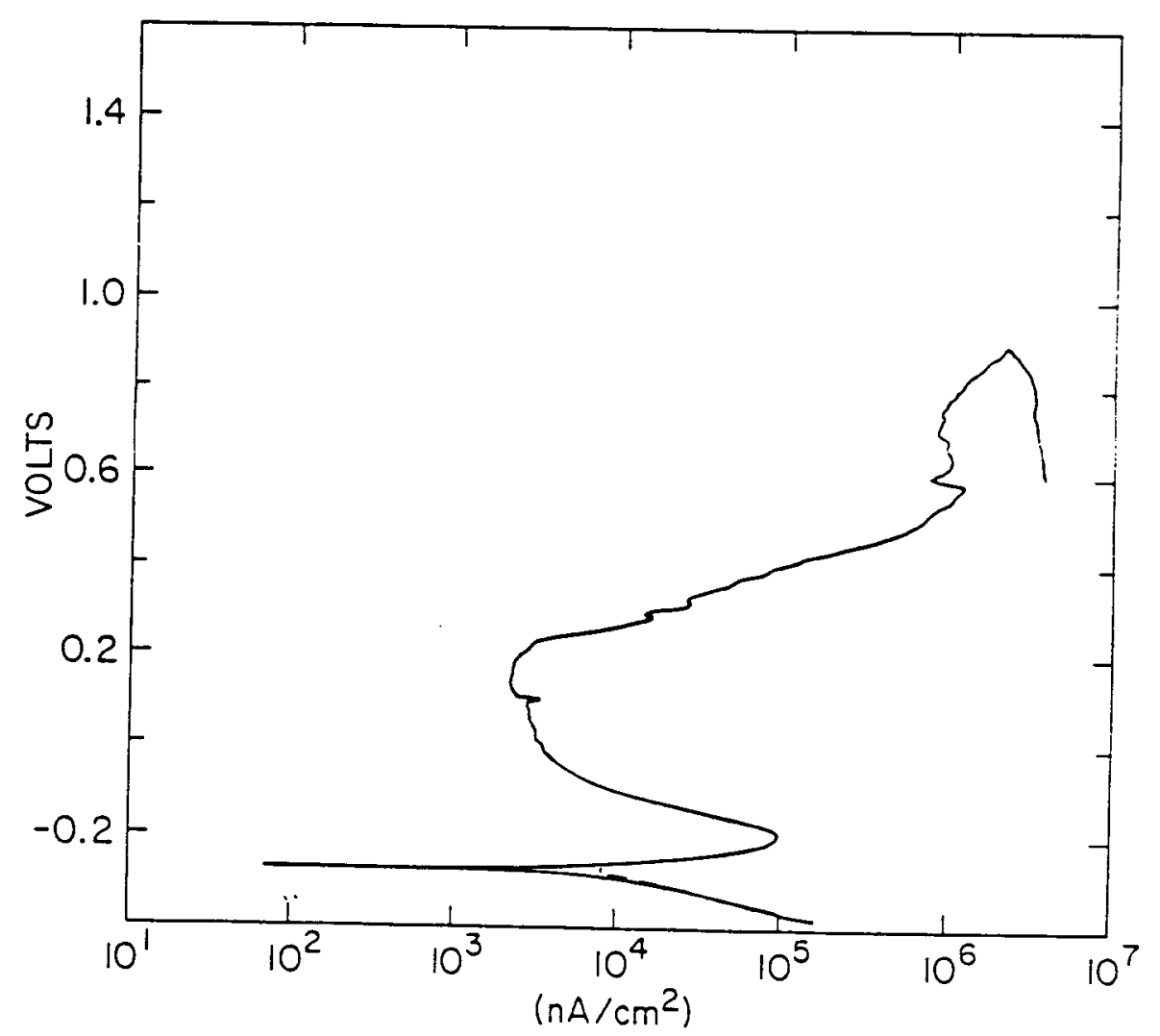

Figure 28. Alloy 825 in $0.5 \mathrm{~N} \mathrm{HCl}+1 \mathrm{~N} \mathrm{NaCl}$ at $25^{\circ} \mathrm{C}$. 


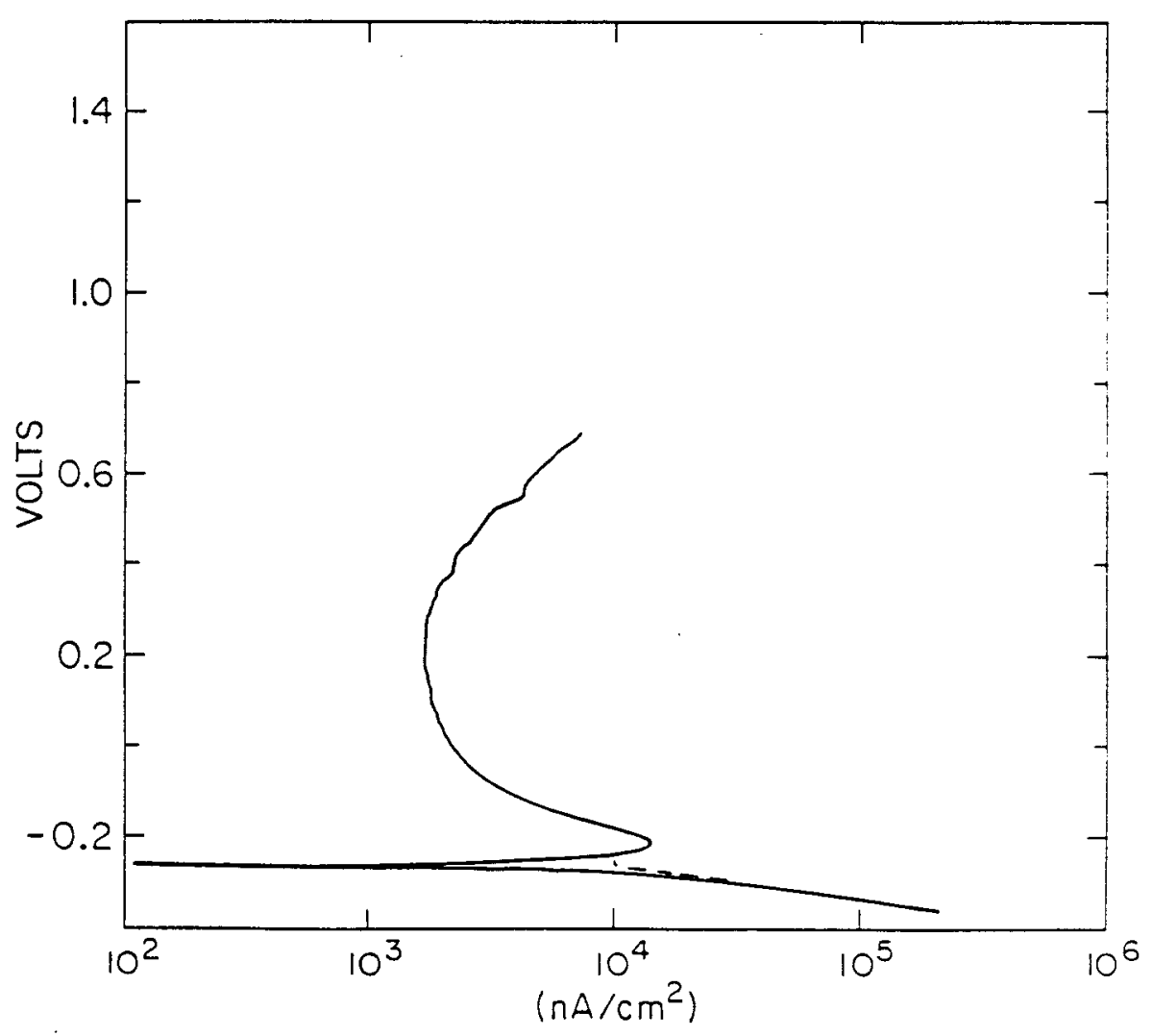

Figure 29. Hastelloy $\mathrm{G}$ in $0.5 \mathrm{~N} \mathrm{HCl}+1 \mathrm{~N} \mathrm{NaCl}$ at $25^{\circ} \mathrm{C}$. 


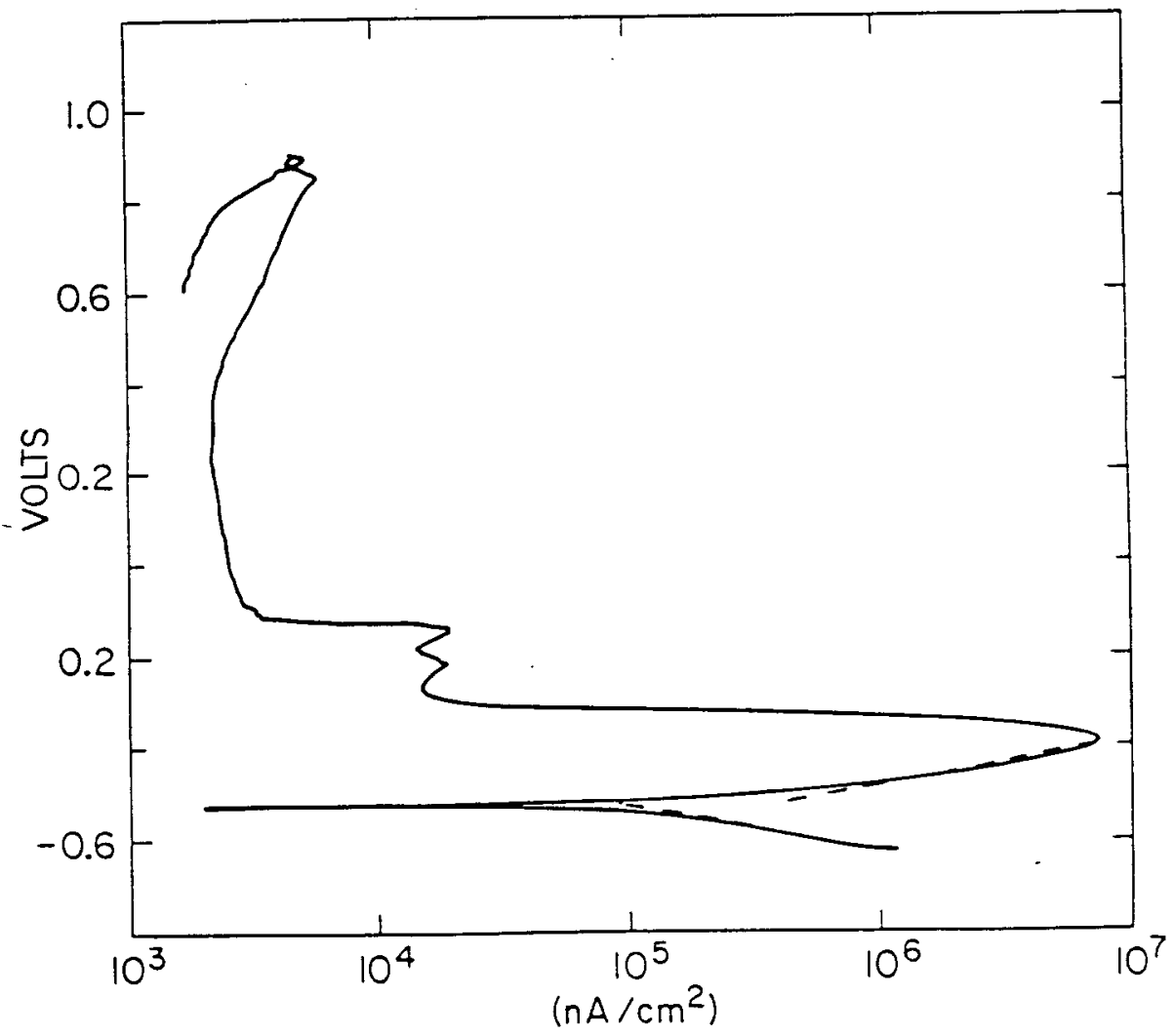

Figure 30. E-Brite Stainless steel in $0.5 \mathrm{~N} \mathrm{HCl}+1 \mathrm{~N} \mathrm{NaCl}$ at $25^{\circ} \mathrm{C}$. 


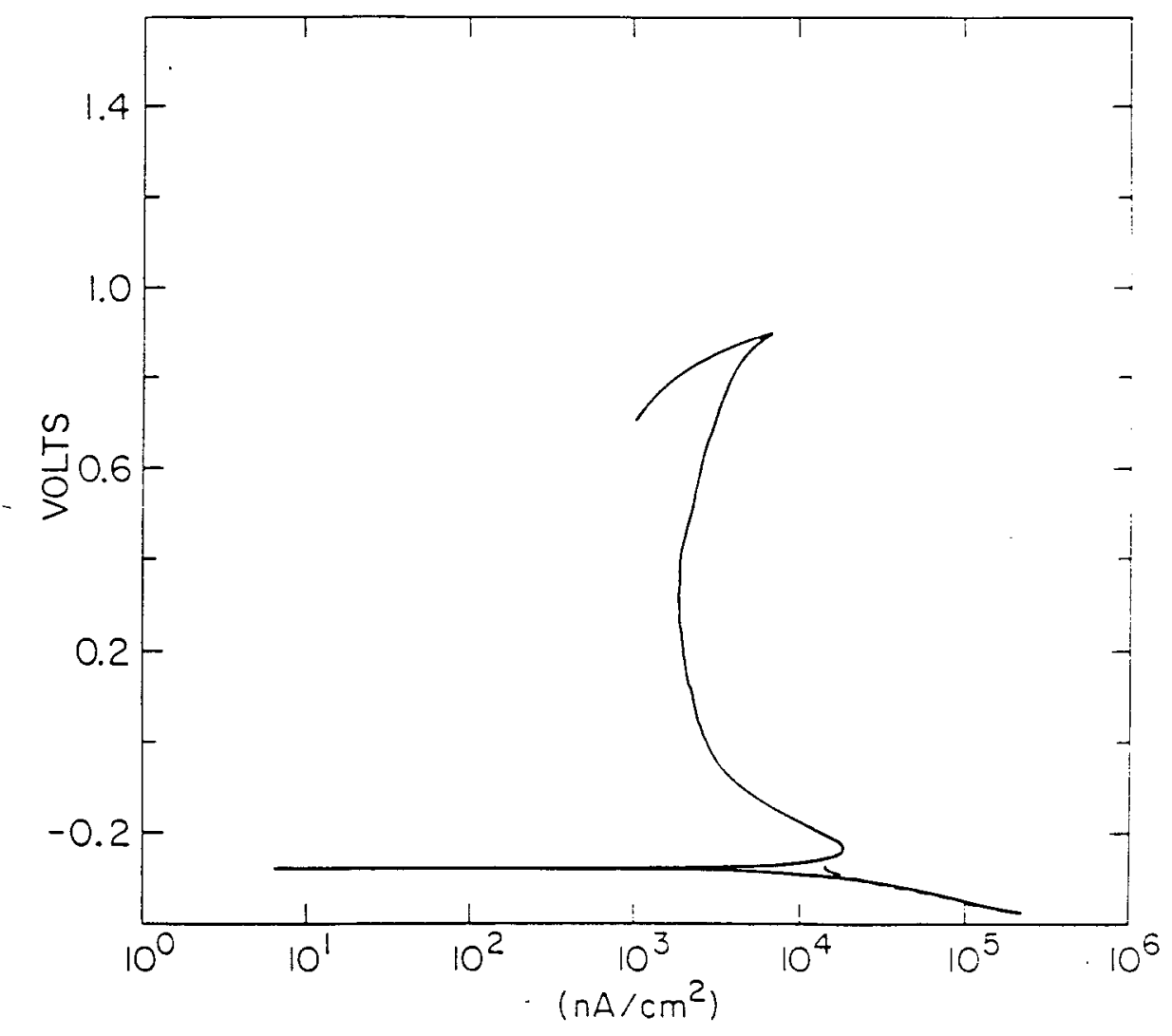

Figure 31. AL-6X Stainless steel in $0.5 \mathrm{~N} \mathrm{HCl}+1 \mathrm{~N} \mathrm{NaCl}$ at $25^{\circ} \mathrm{C}$. 


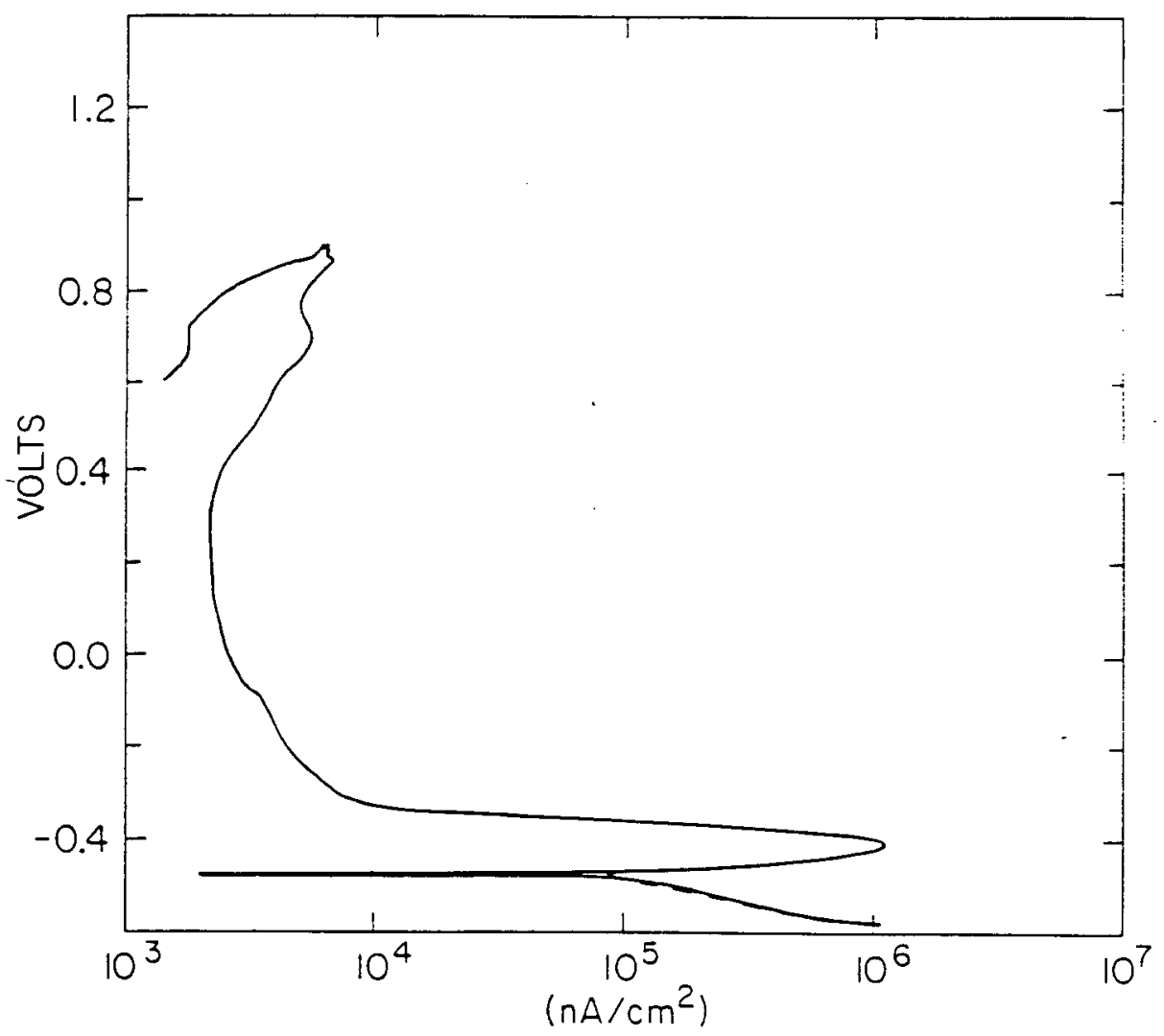

Figure 32. $29-4 \mathrm{Cr}$-Mo Stainless steel in $0.5 \mathrm{~N} \mathrm{HCl}+1 \mathrm{~N} \mathrm{NaCl}$ at $25^{\circ} \mathrm{C}$ 


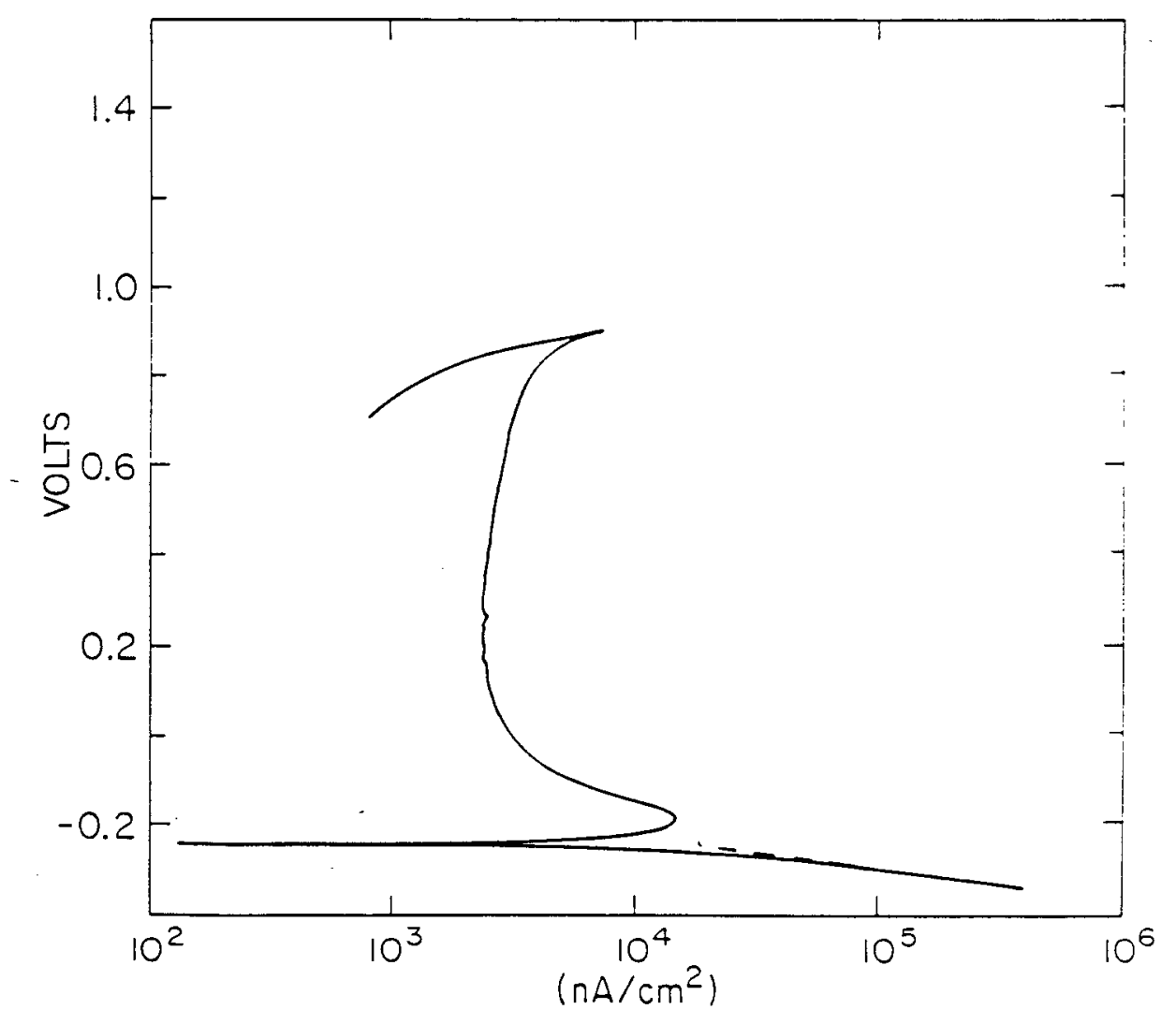

Figure 33. Stainless Alloy 625 in $0.5 \mathrm{~N} \mathrm{HCl}+1 \mathrm{~N} \mathrm{NaCl}$ at $25^{\circ} \mathrm{C}$. 


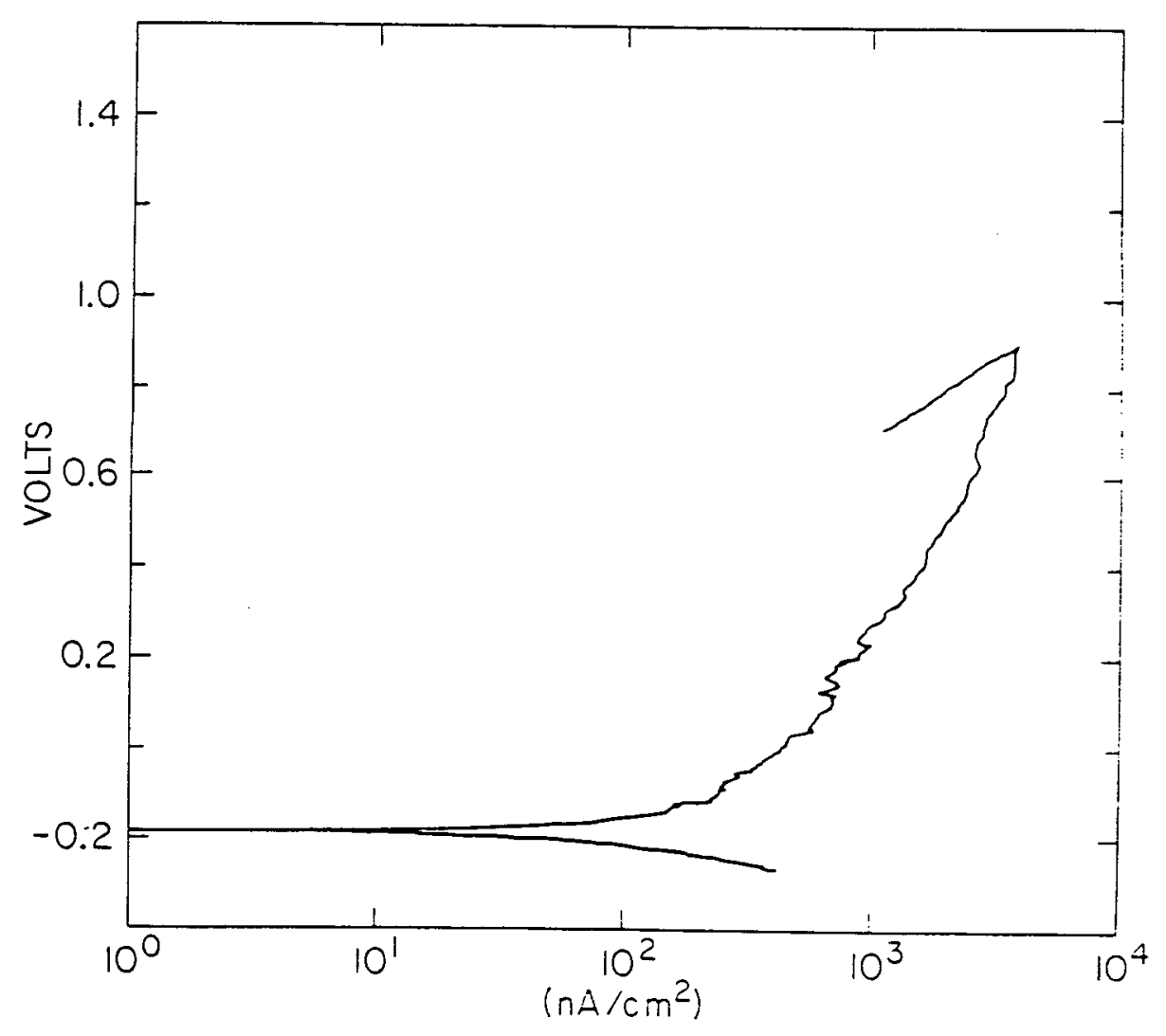

Figure 34. Hastelloy $\mathrm{C} 276$ in $0.5 \mathrm{~N} \mathrm{HCl}+1 \mathrm{~N} \mathrm{NaCl}$ at $25^{\circ} \mathrm{C}$. 


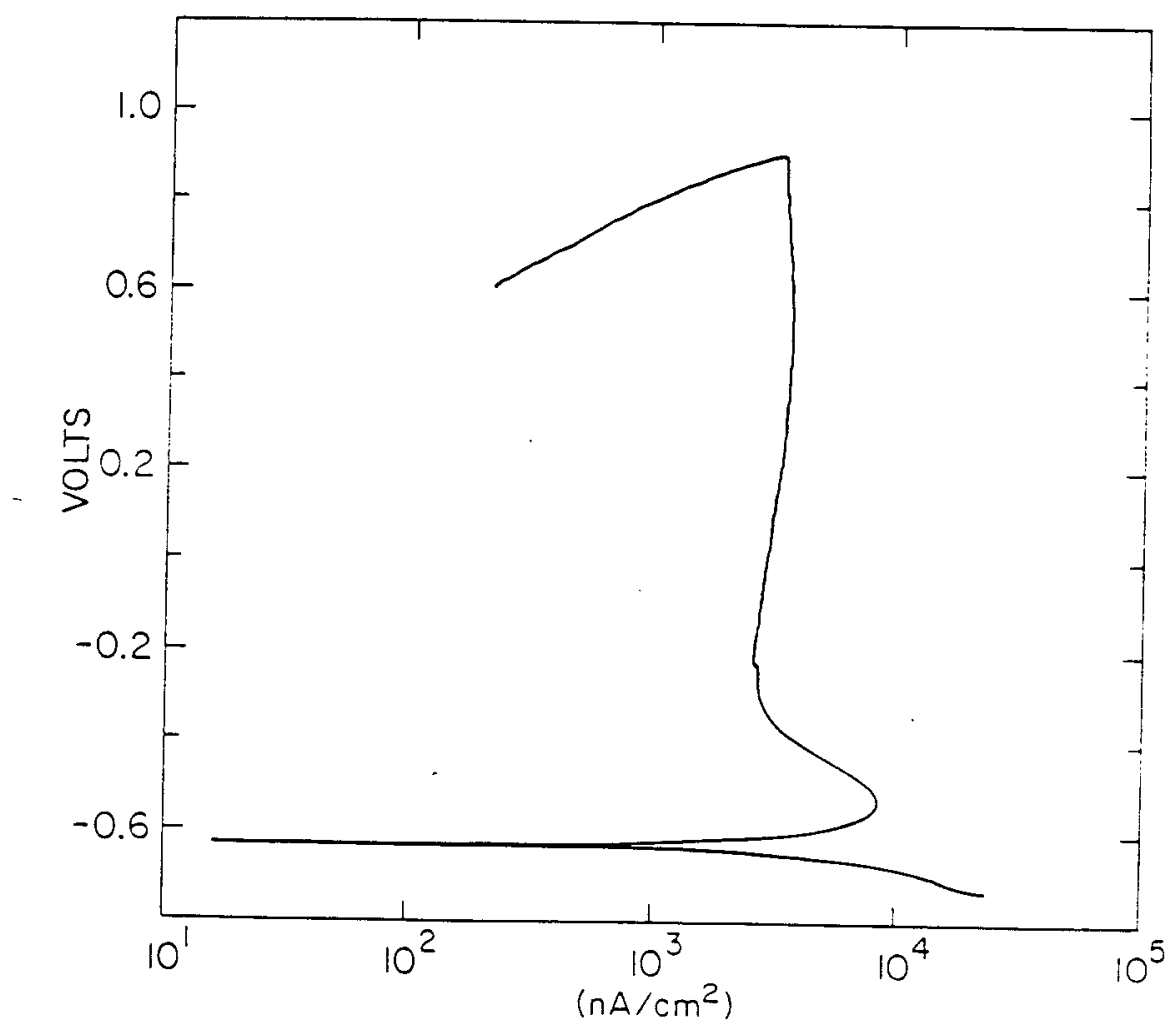

Figure 35. Commercial Titanium in $0.5 \mathrm{~N} \mathrm{HCl}+1 \mathrm{~N} \mathrm{NaCl}$ at $25^{\circ} \mathrm{C}$. 


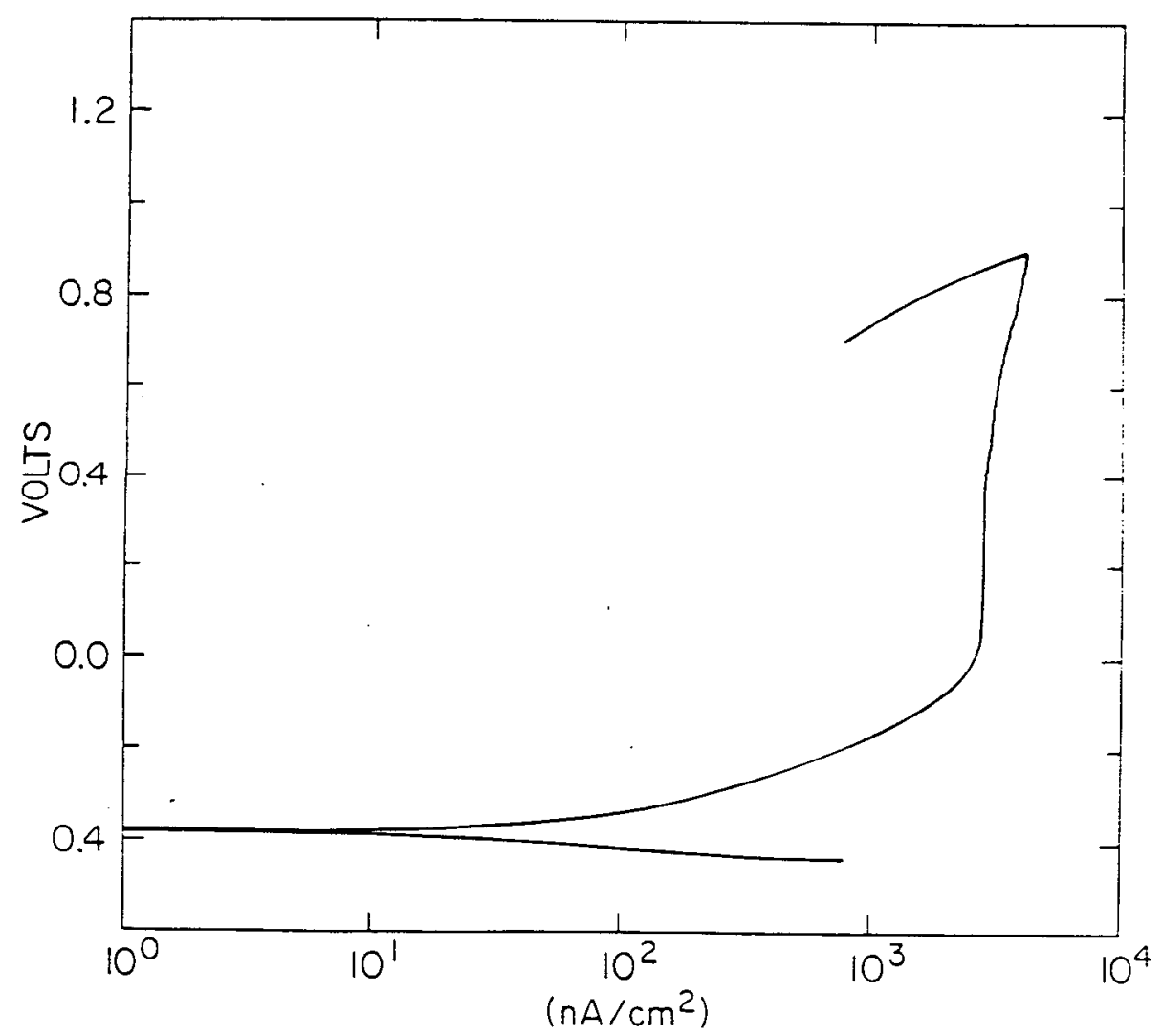

Figure 36. Ti-Code 12 in $0.5 \mathrm{~N} \mathrm{HCl}+1 \mathrm{~N} \mathrm{NaCl}$ at $25^{\circ} \mathrm{C}$. 


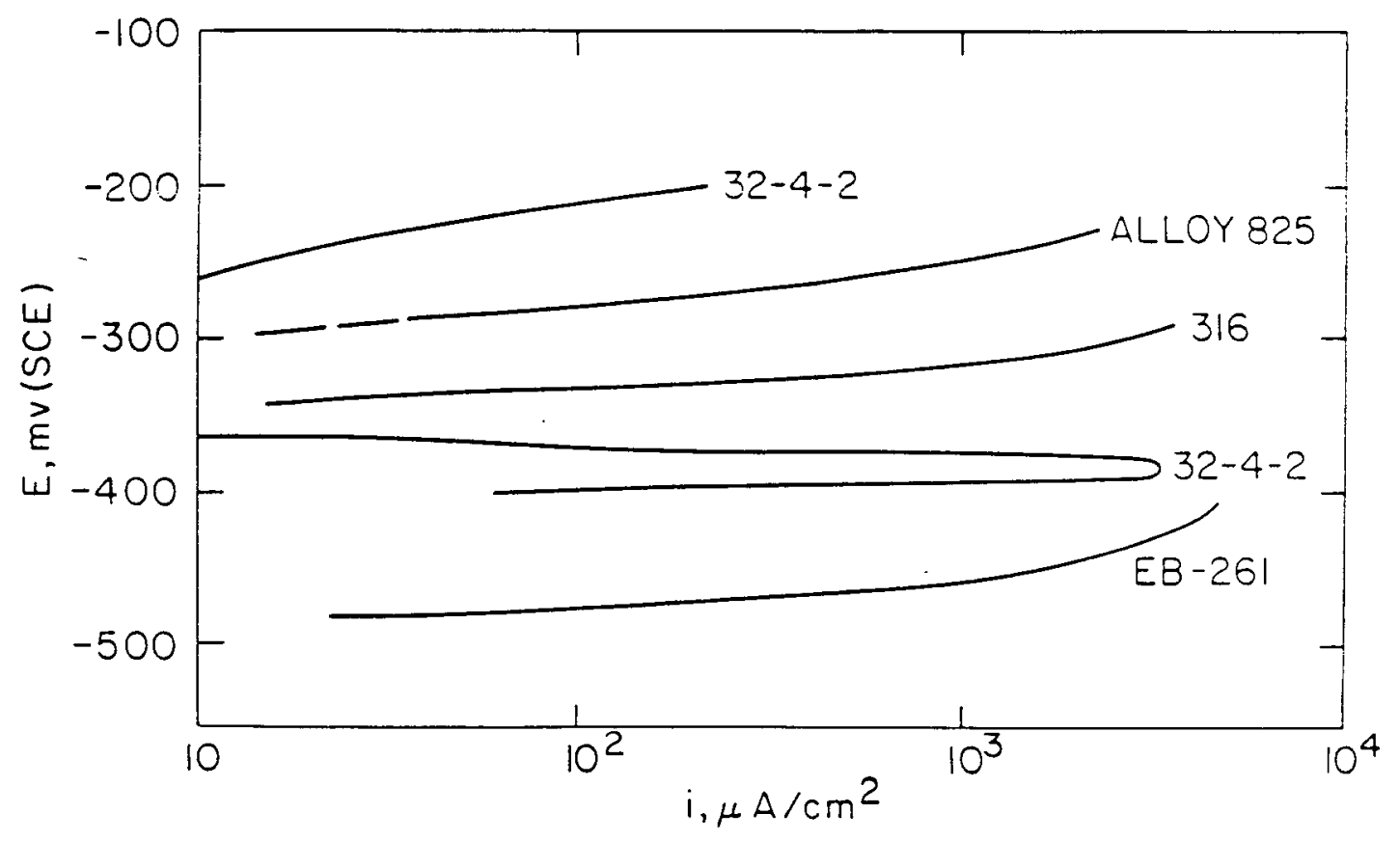

Figure 37. 316 Stainless Steel, E-Brite 26-1, Alloy 825 and $32 \mathrm{Cr}$ steel in $0.5 \mathrm{~N} \mathrm{HCl}+1 \mathrm{~N} \mathrm{NaCl}$ at $50^{\circ} \mathrm{C}$. 


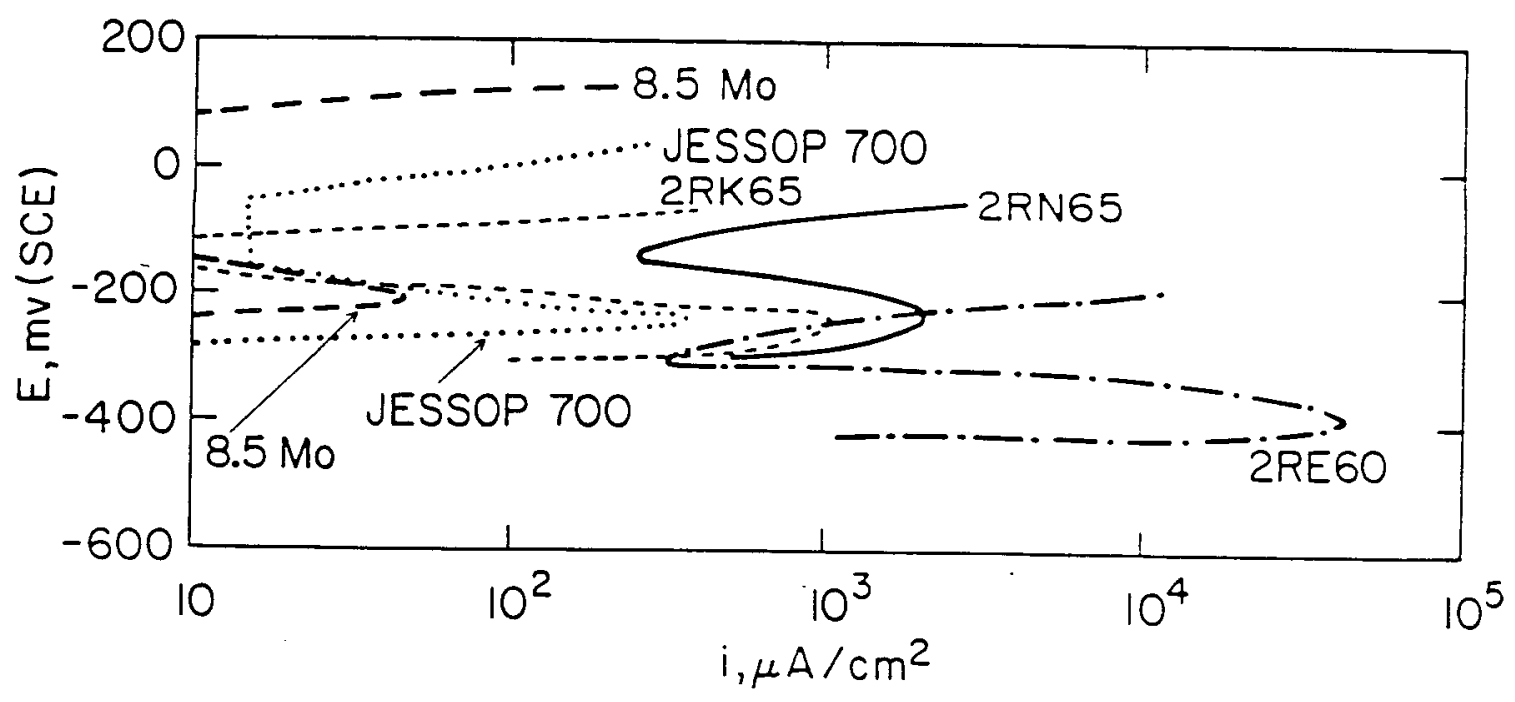

Figure 38. Jessop 700, 2RN65, 2RK65 and

8 -Mo Stainless Steel in $0.5 \mathrm{~N} \mathrm{HCl}+1 \mathrm{~N} \mathrm{NaCl}$ at $50^{\circ} \mathrm{C}$. 


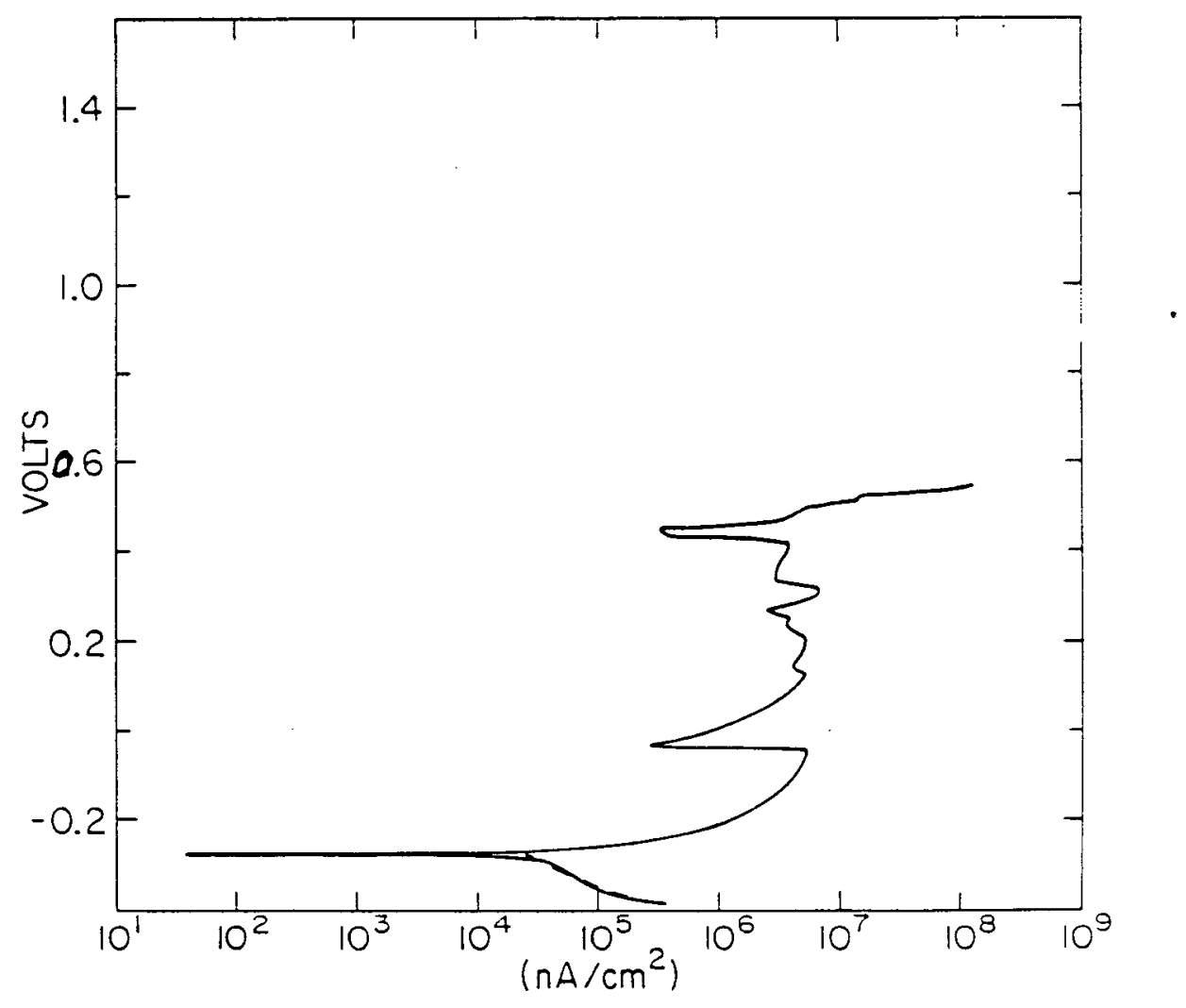

Figure 39. Carpenter $20 \mathrm{Cb}-3$ and 2RE60 Stainless Steel in $0.5 \mathrm{~N} \mathrm{HCl}+1 \mathrm{~N} \mathrm{NaCl}$ at $50^{\circ} \mathrm{C}$. 


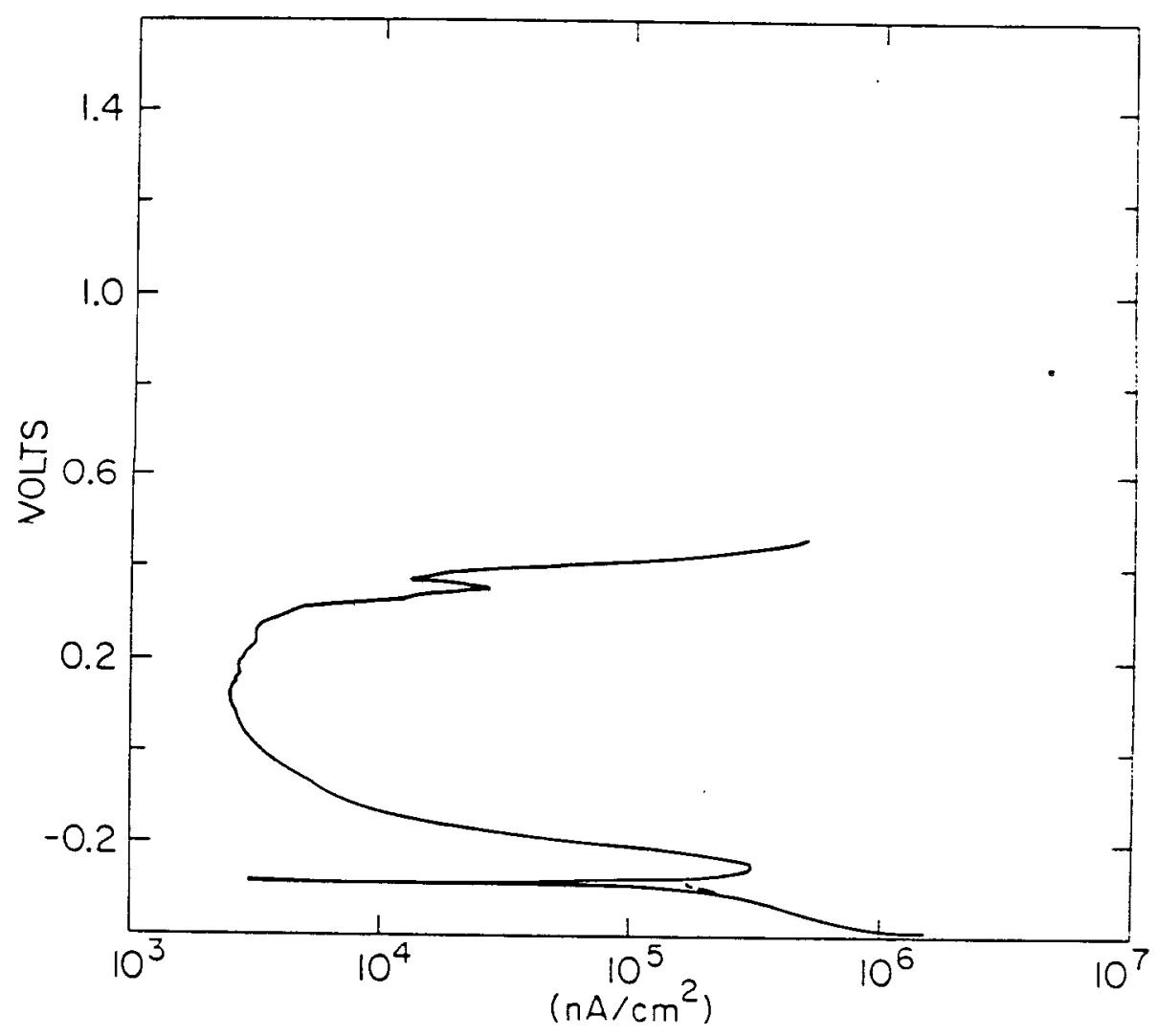

Figure 41. AL- $6 \mathrm{X}$ Stainless steel in $0.5 \mathrm{~N} \mathrm{HCl}+1 \mathrm{~N} \mathrm{NaCl}$ at $50^{\circ} \mathrm{C}$. 


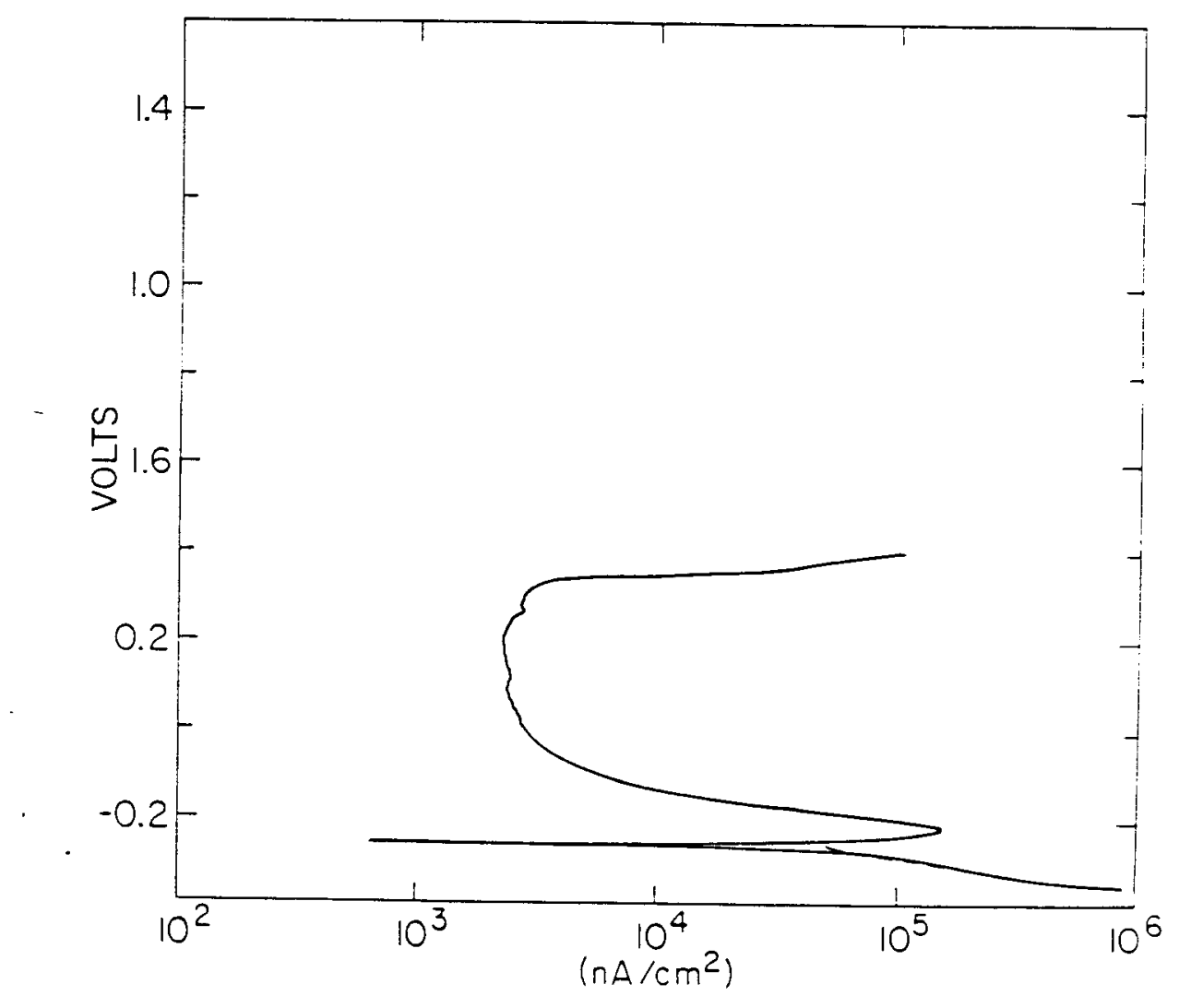

Figure 42. Hastelloy $\mathrm{G}$ in $0.5 \mathrm{~N} \mathrm{HCl}+1 \mathrm{~N} \mathrm{NaCl}$ at $50^{\circ} \mathrm{C}$. 


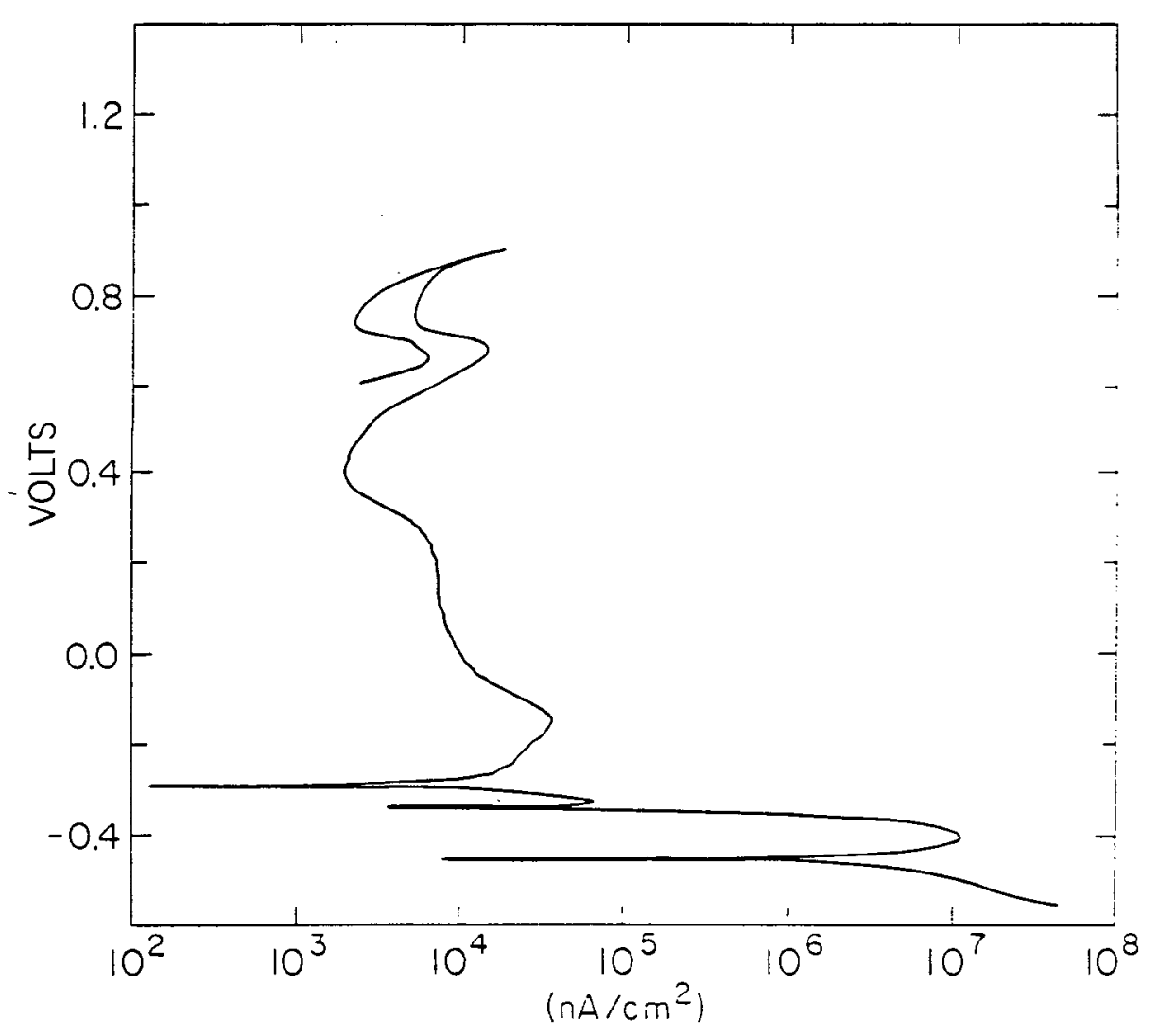

Figure 43. 29-4 $\mathrm{Cr}$-Mo Stainless steel in $0.5 \mathrm{~N} \mathrm{HCl}+1 \mathrm{~N} \mathrm{NaCl}$ at $50^{\circ} \mathrm{C}$. 


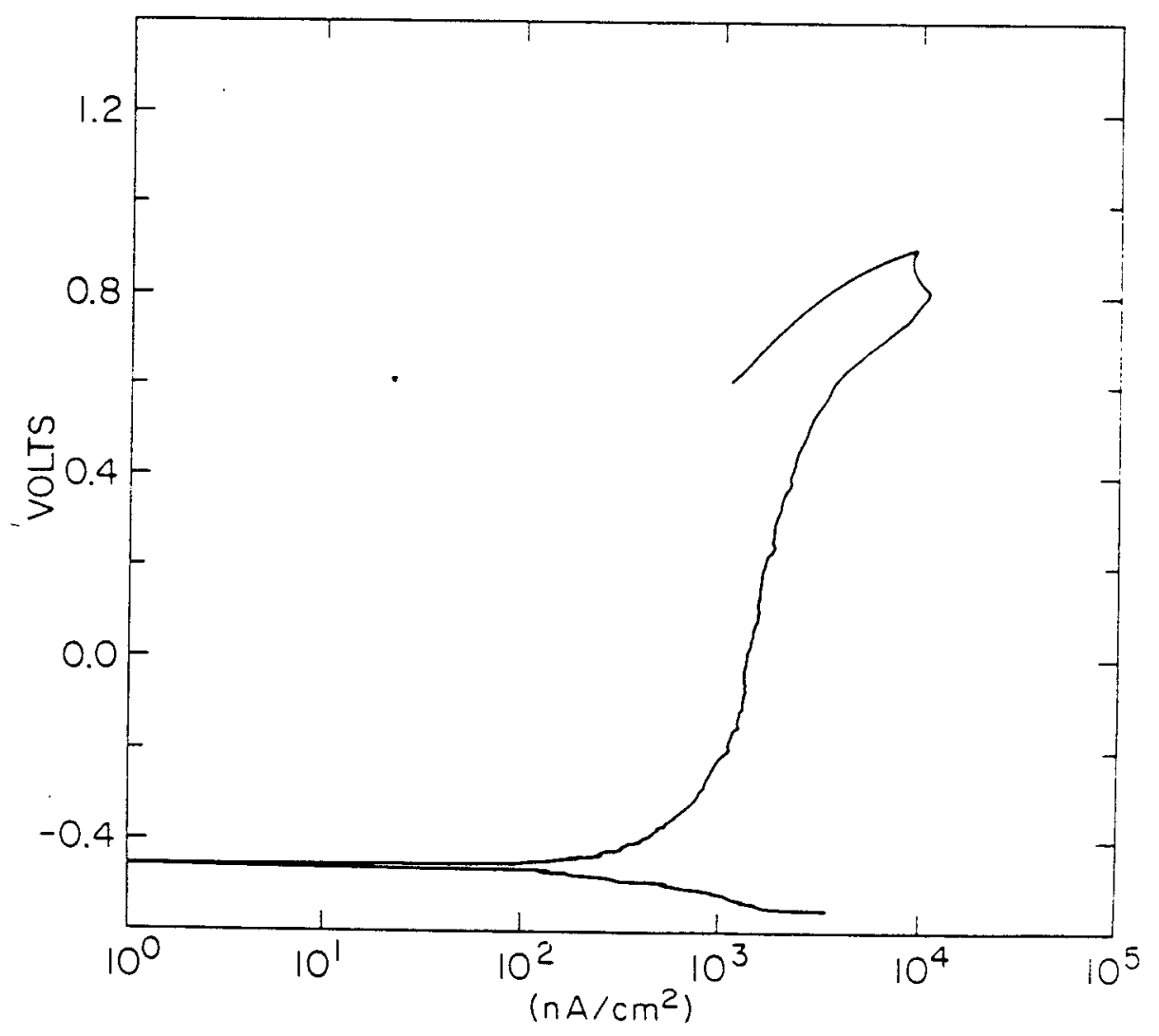

Figure 44. 29-4 Cr-Mo Stainless steel in $0.5 \mathrm{~N} \mathrm{HCl}+1 \mathrm{~N} \mathrm{NaCl}$ at $50^{\circ} \mathrm{C}$. 


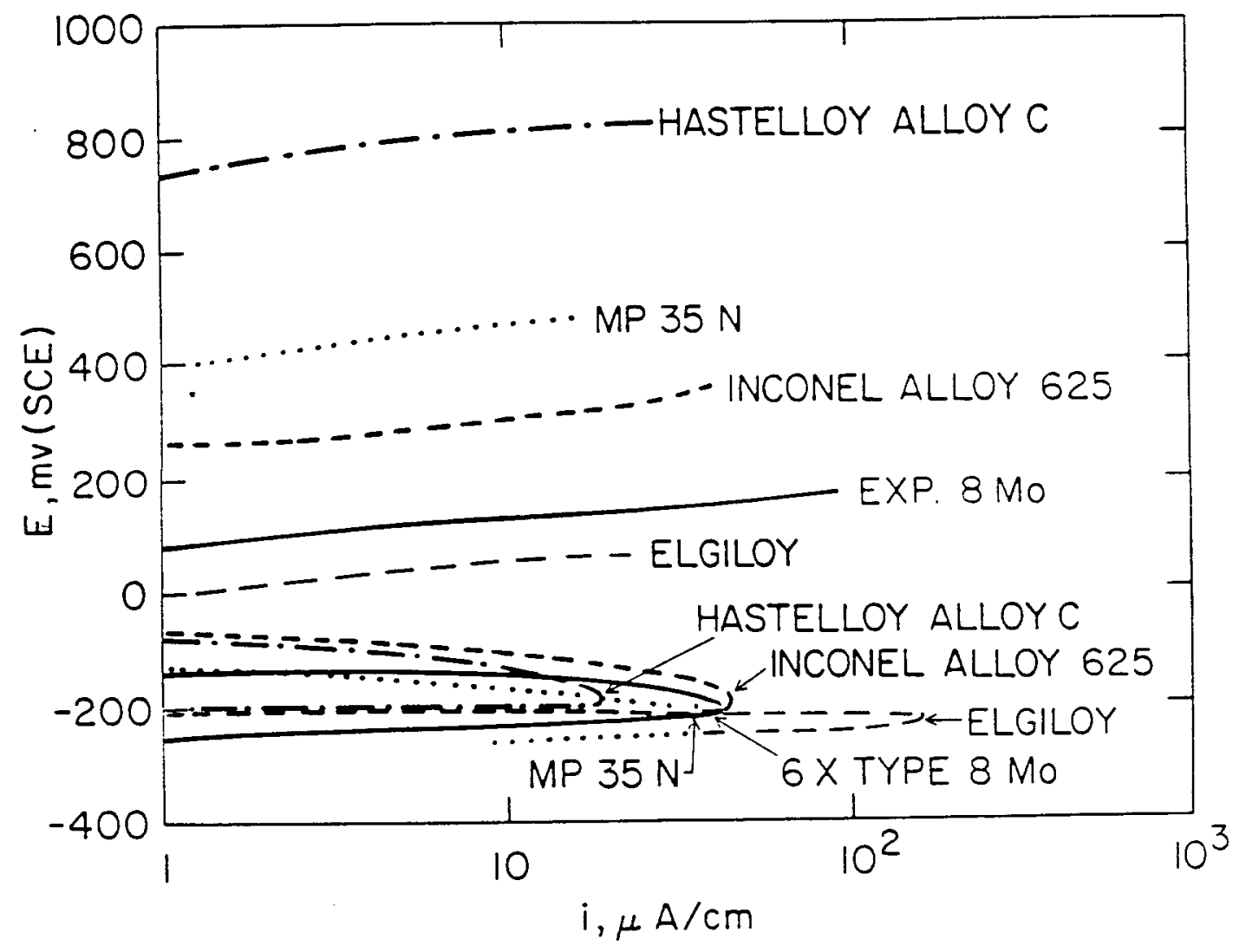

Figure 45. Stainless Alloys 625, Hastelloy $C$, and MP $35 \mathrm{~N}$ in $0.5 \mathrm{~N} \mathrm{HCl}+1 \mathrm{~N} \mathrm{NaCl}$ at $50^{\circ} \mathrm{C}$. 


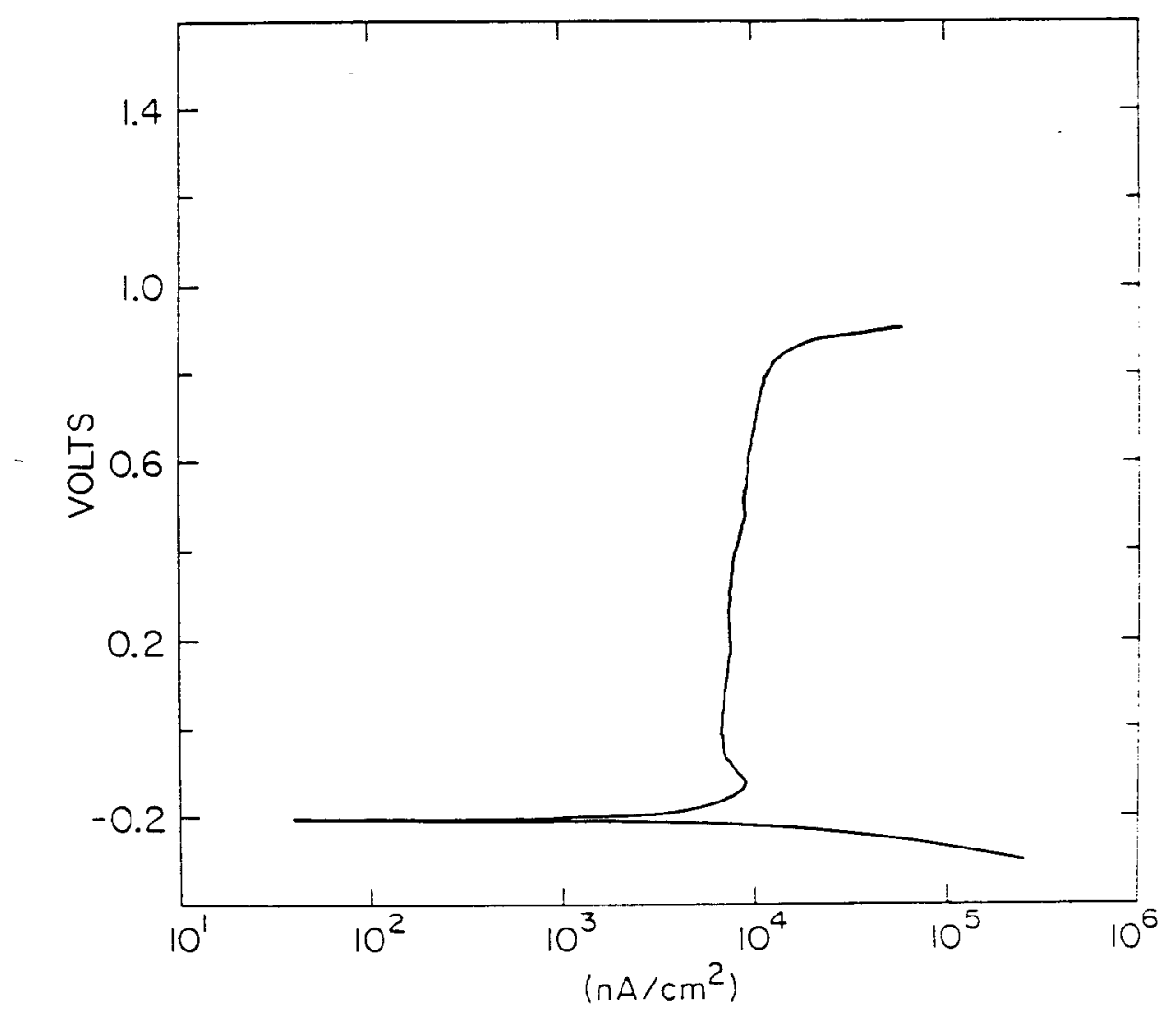

Figure 46. Hastelloy $\mathrm{C}-276$ in $0.5 \mathrm{~N} \mathrm{HCl}+1 \mathrm{~N} \mathrm{NaCl}$ at $50^{\circ} \mathrm{C}$. 


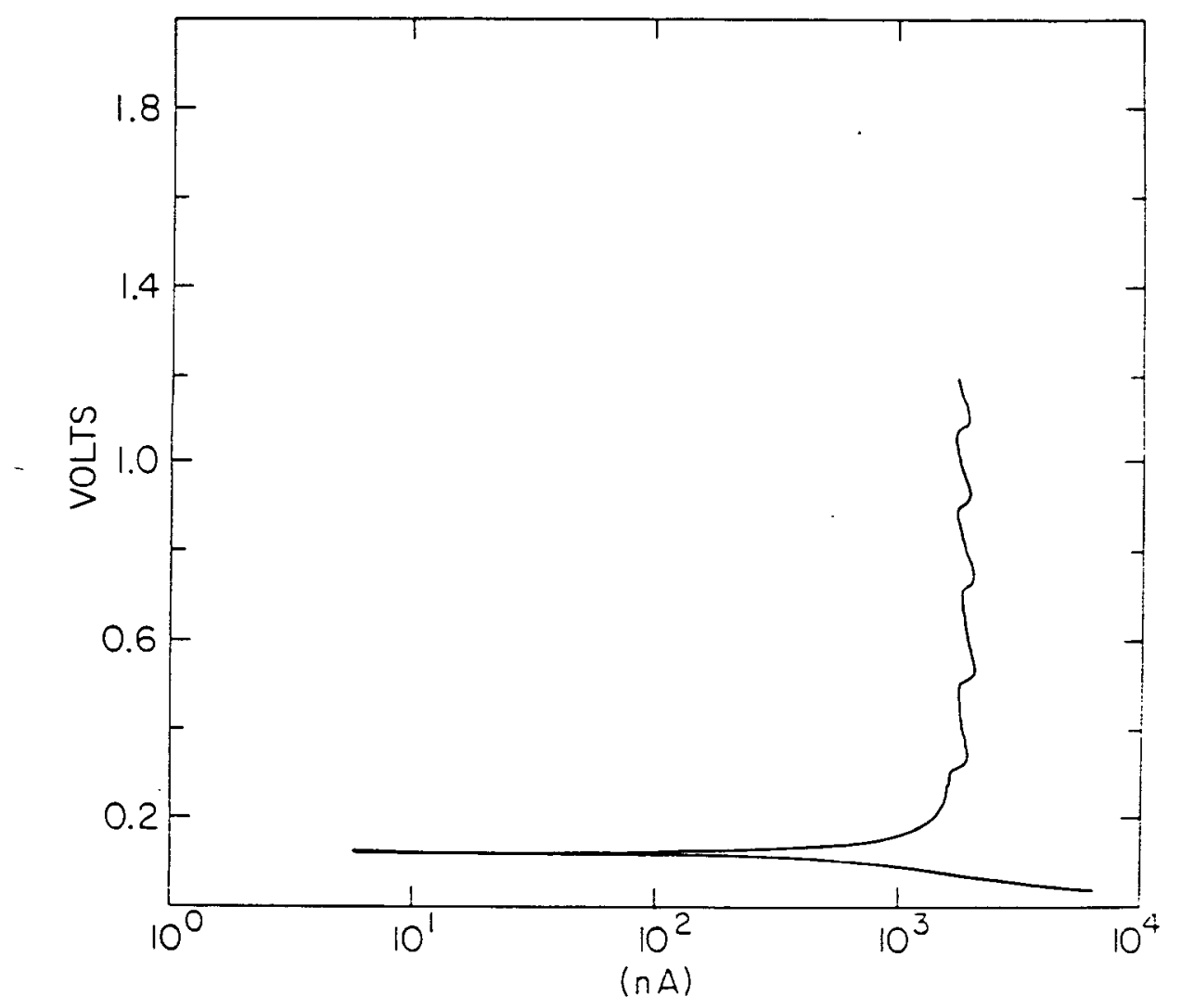

Figure 47. Ti-Code 12 in $0.5 \mathrm{~N} \mathrm{HCl}+1 \mathrm{~N} \mathrm{NaCl}$ at $50^{\circ} \mathrm{C}$. 


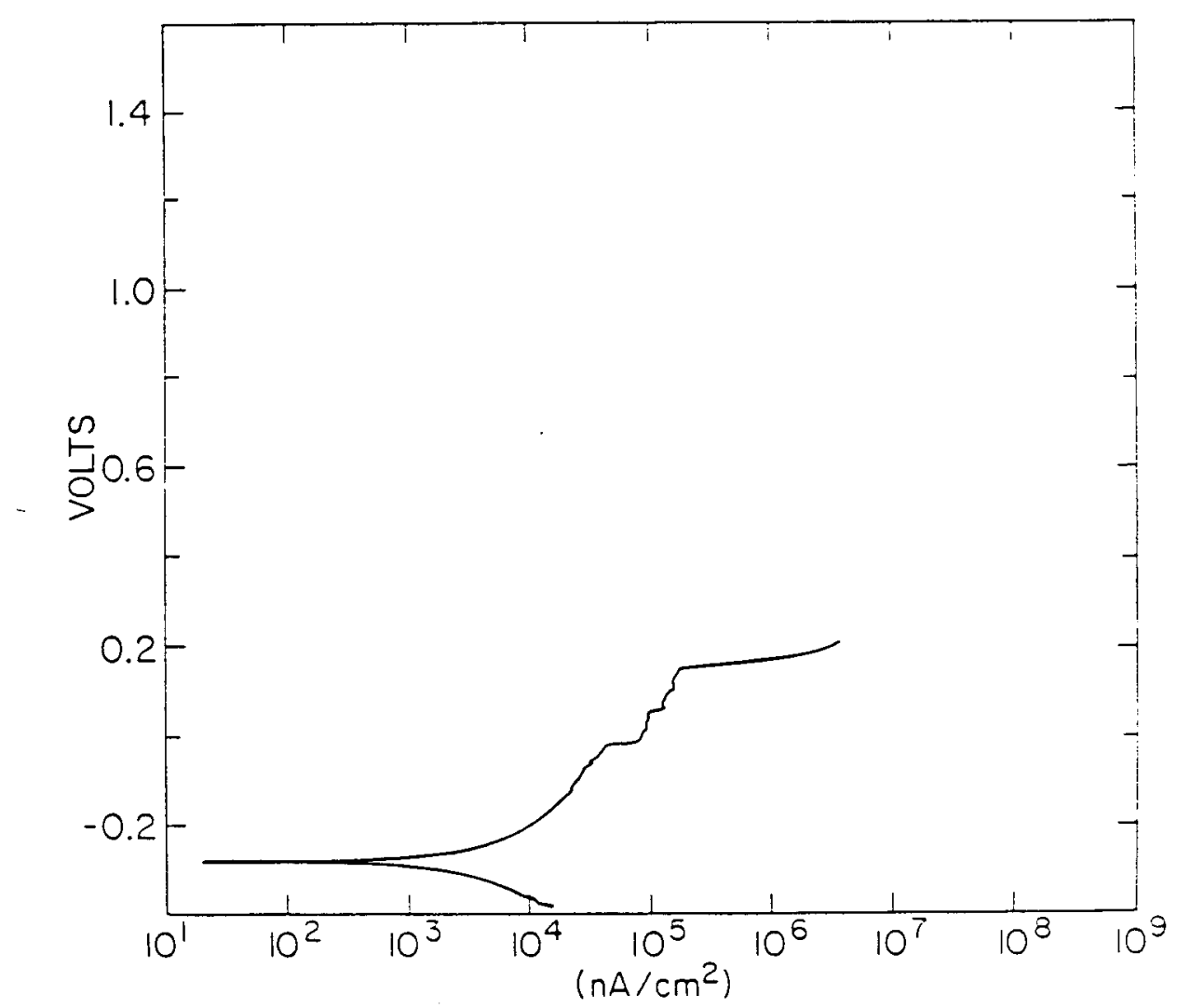

Figure 48. AL-6X Stainless steel in $0.5 \mathrm{~N} \mathrm{HCl}+1 \mathrm{~N} \mathrm{NaCl}$ at $70^{\circ} \mathrm{C}$. 


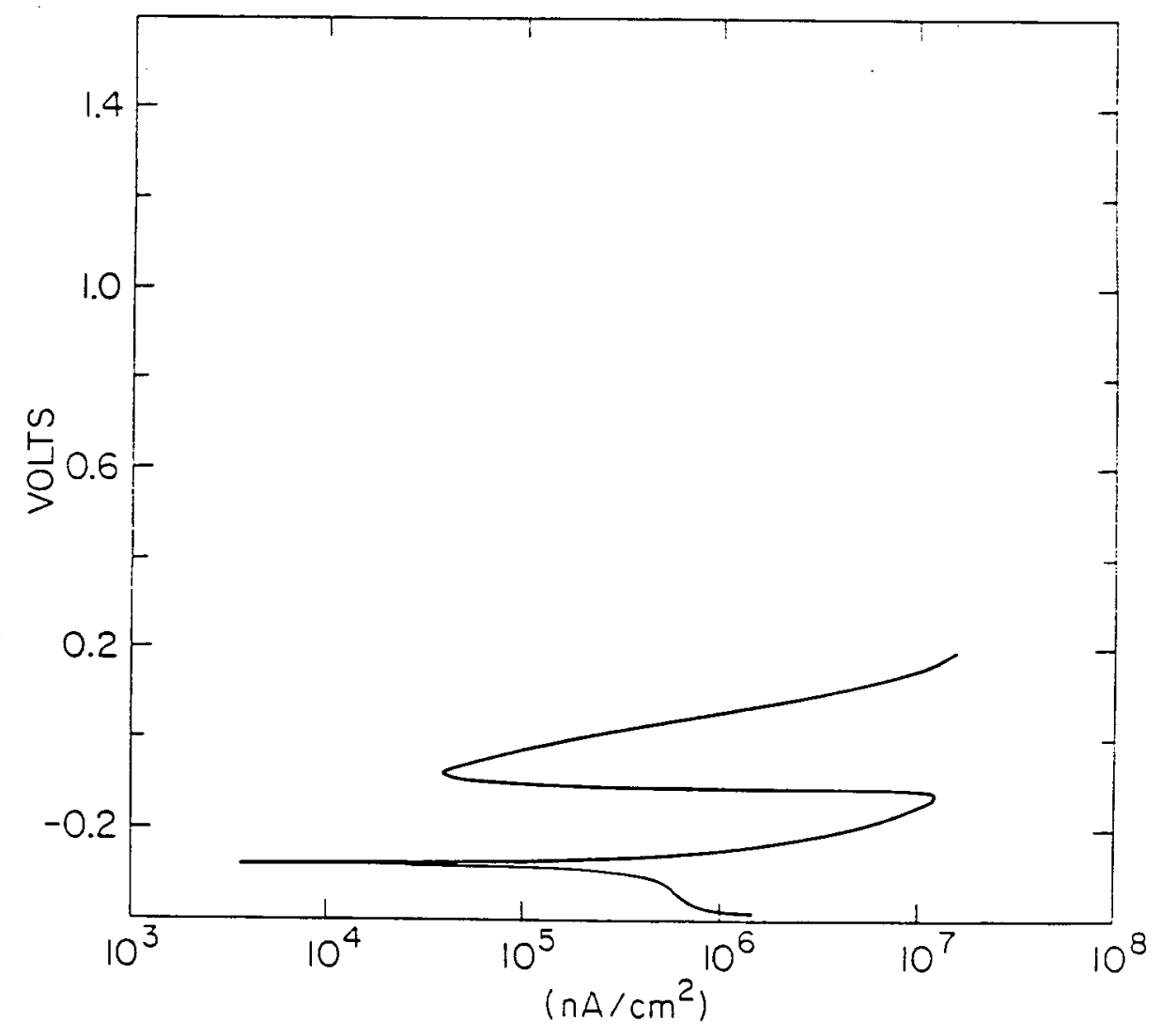

Figure 49. Stainless Alloy 825 in $0.5 \mathrm{~N} \mathrm{HCl}+1 \mathrm{~N} \mathrm{NaCl}$ at $70^{\circ} \mathrm{C}$. 


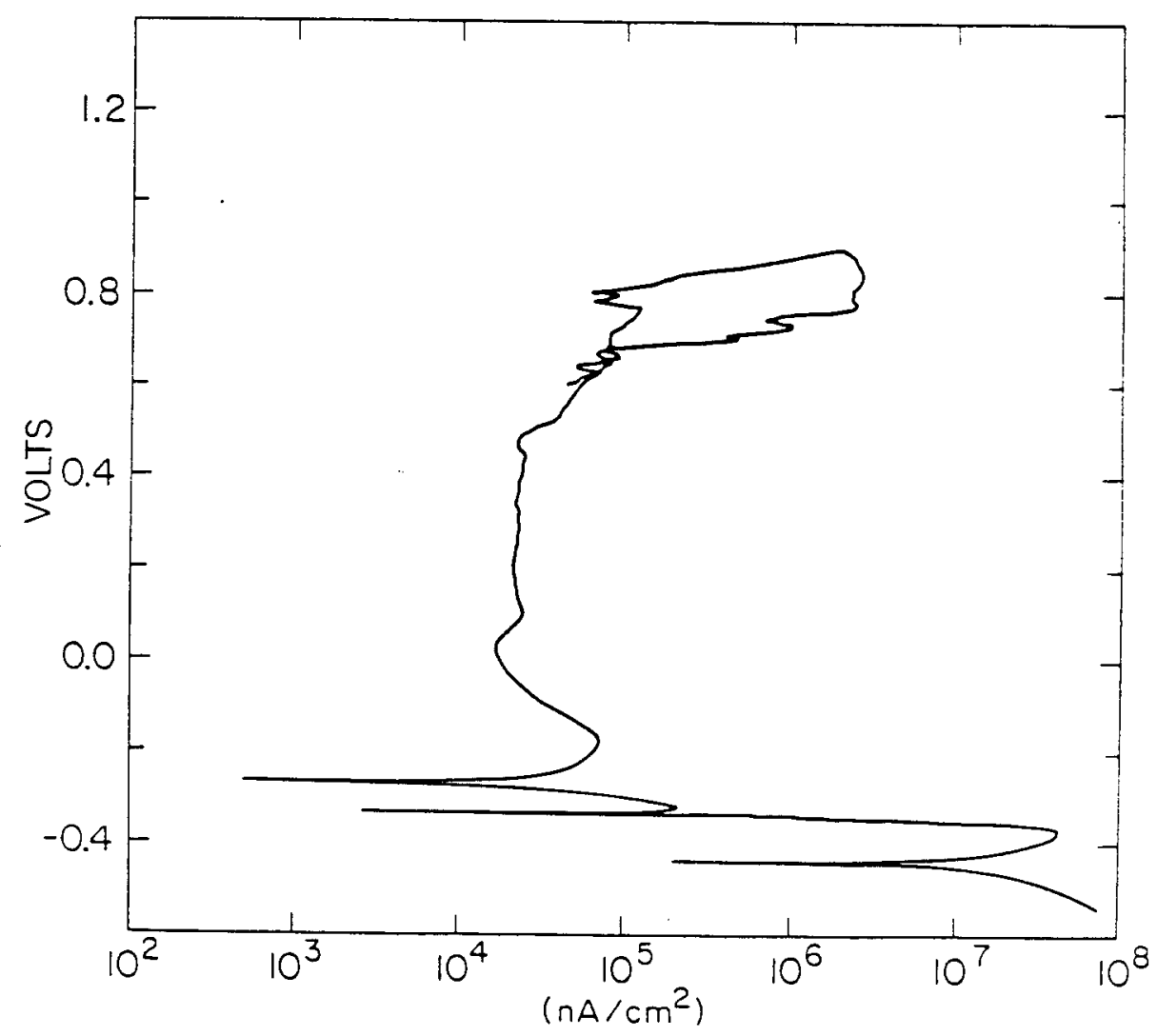

Figure 50. 29-4 Cr-Mo Stainless steel in $0.5 \mathrm{~N} \mathrm{HCl}+1 \mathrm{~N} \mathrm{NaCl}$ at $70^{\circ} \mathrm{C}$. 


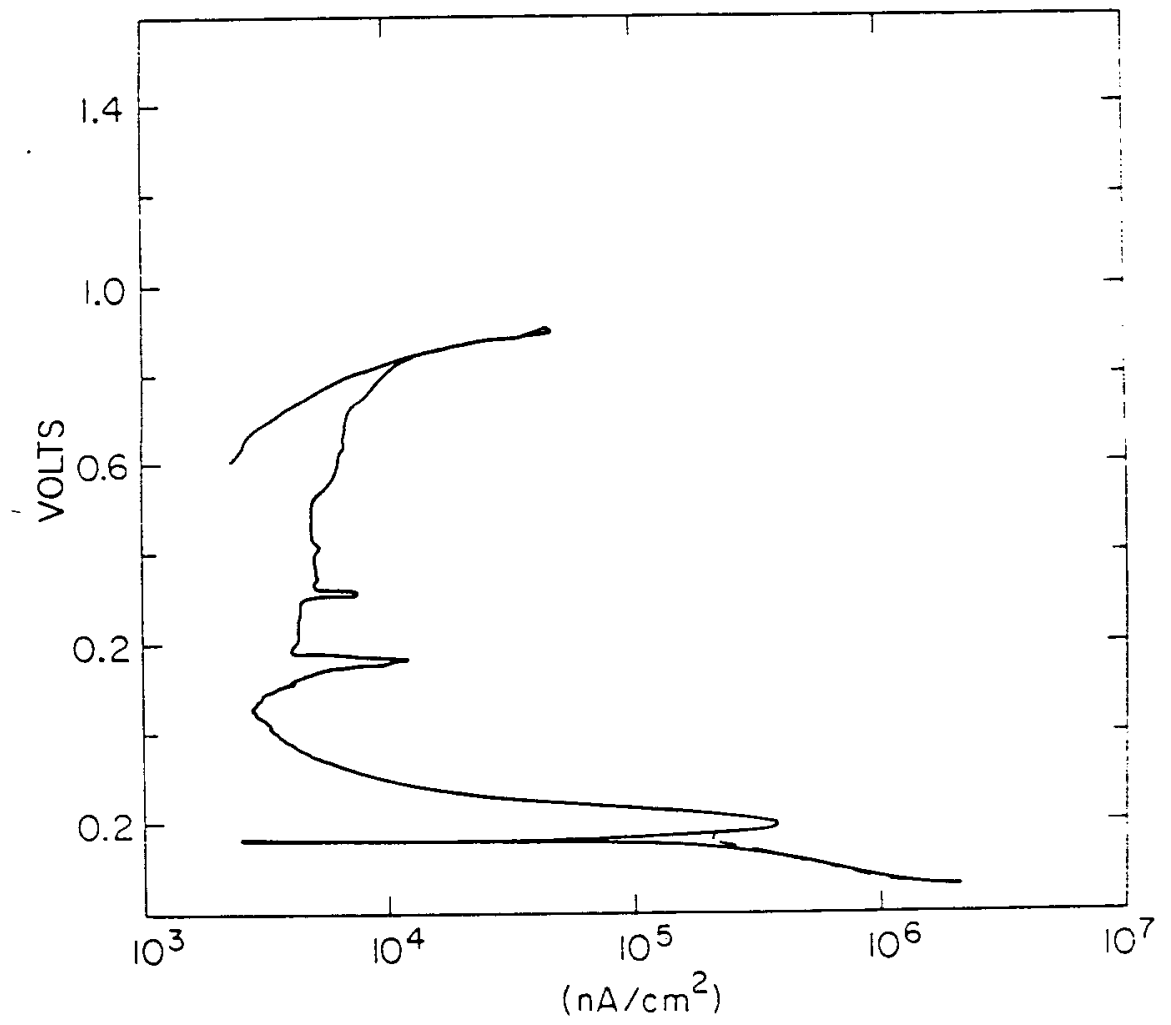

Figure 51. Alloy 625 in $0.5 \mathrm{~N} \mathrm{HCl}+1 \mathrm{~N} \mathrm{NaCl}$ at $70^{\circ} \mathrm{C}$.

$-74-$ 


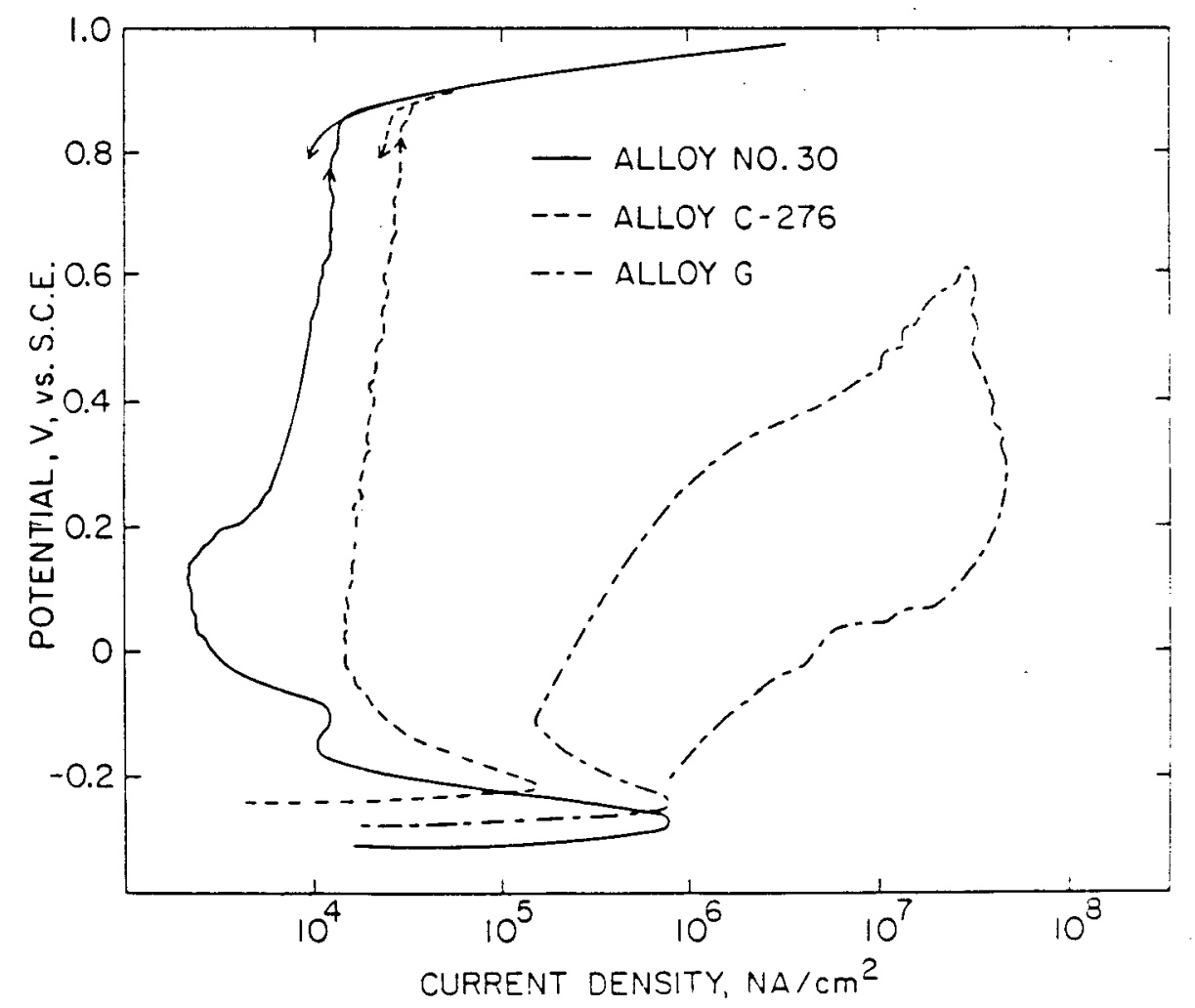

Figure 52. Experimental Stainless Steel alloy $\# 30$ and Hastelloy $\mathrm{C}-276$ and $\mathrm{G}$ in $0.5 \mathrm{~N} \mathrm{HCl}+1 \mathrm{~N} \mathrm{NaCl}$ at $70^{\circ} \mathrm{C}$. 


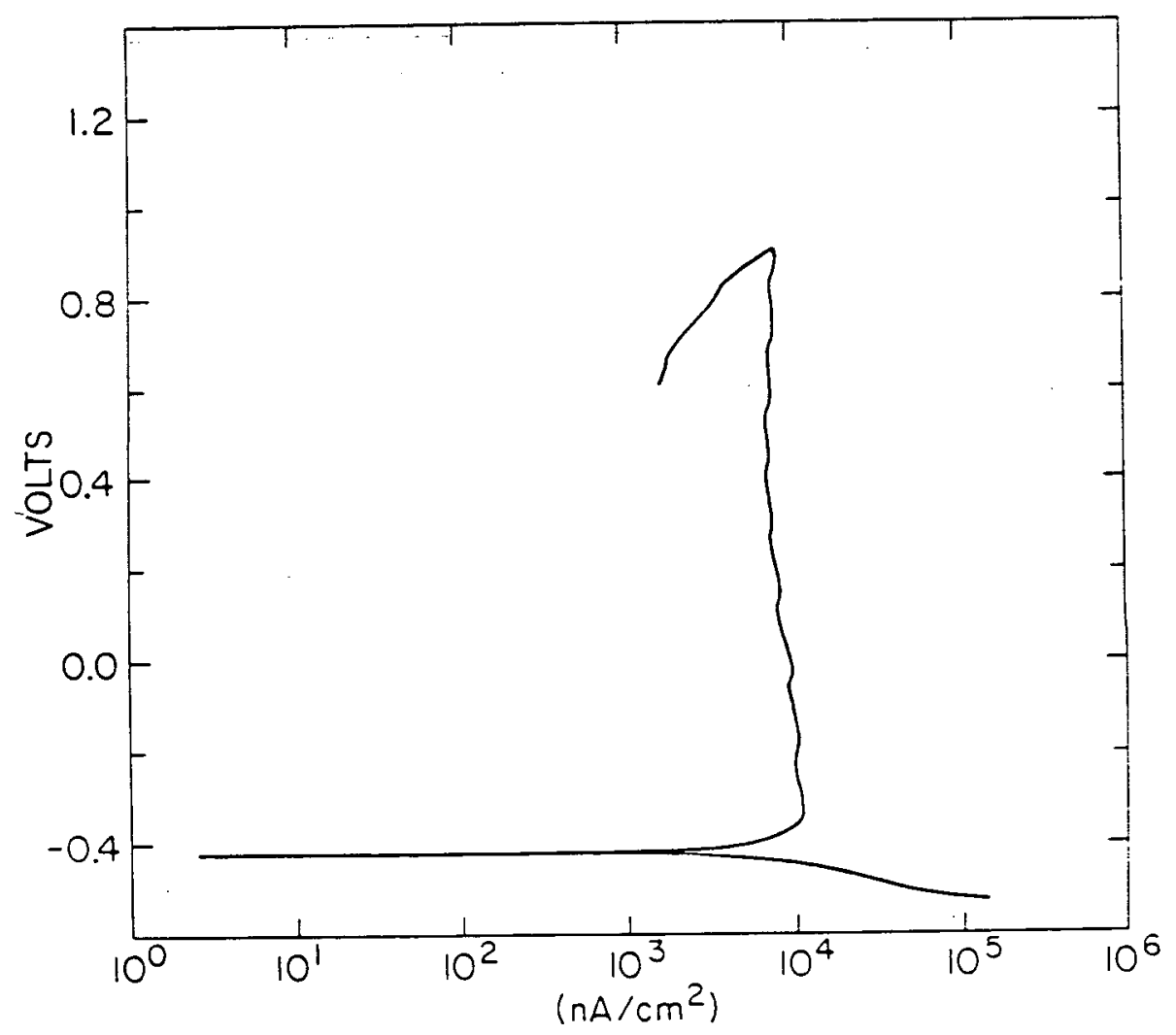

Figure 53. Ti-Code 12 in $0.5 \mathrm{~N} \mathrm{HCl}+1 \mathrm{~N} \mathrm{NaCl}$ at $90^{\circ} \mathrm{C}$.

$$
-76-
$$




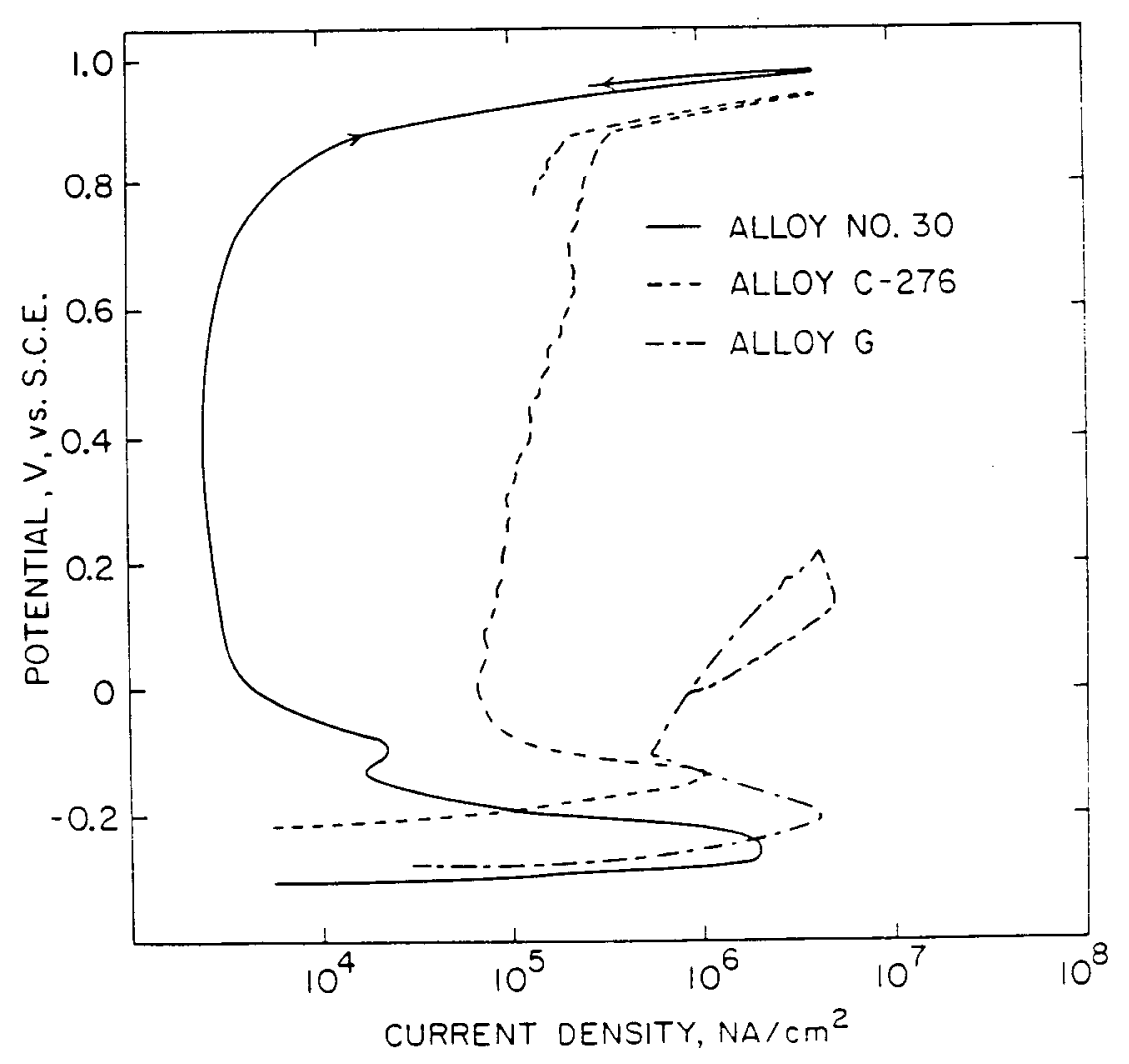

Figure 54. Hastelloy $\mathrm{G}$ and $\mathrm{C}-276$ and Experimental alloy $\# 30$ in $0.5 \mathrm{~N} \mathrm{HCl}+2 \mathrm{~N} \mathrm{NaCl}$ at $70^{\circ} \mathrm{C}$. 


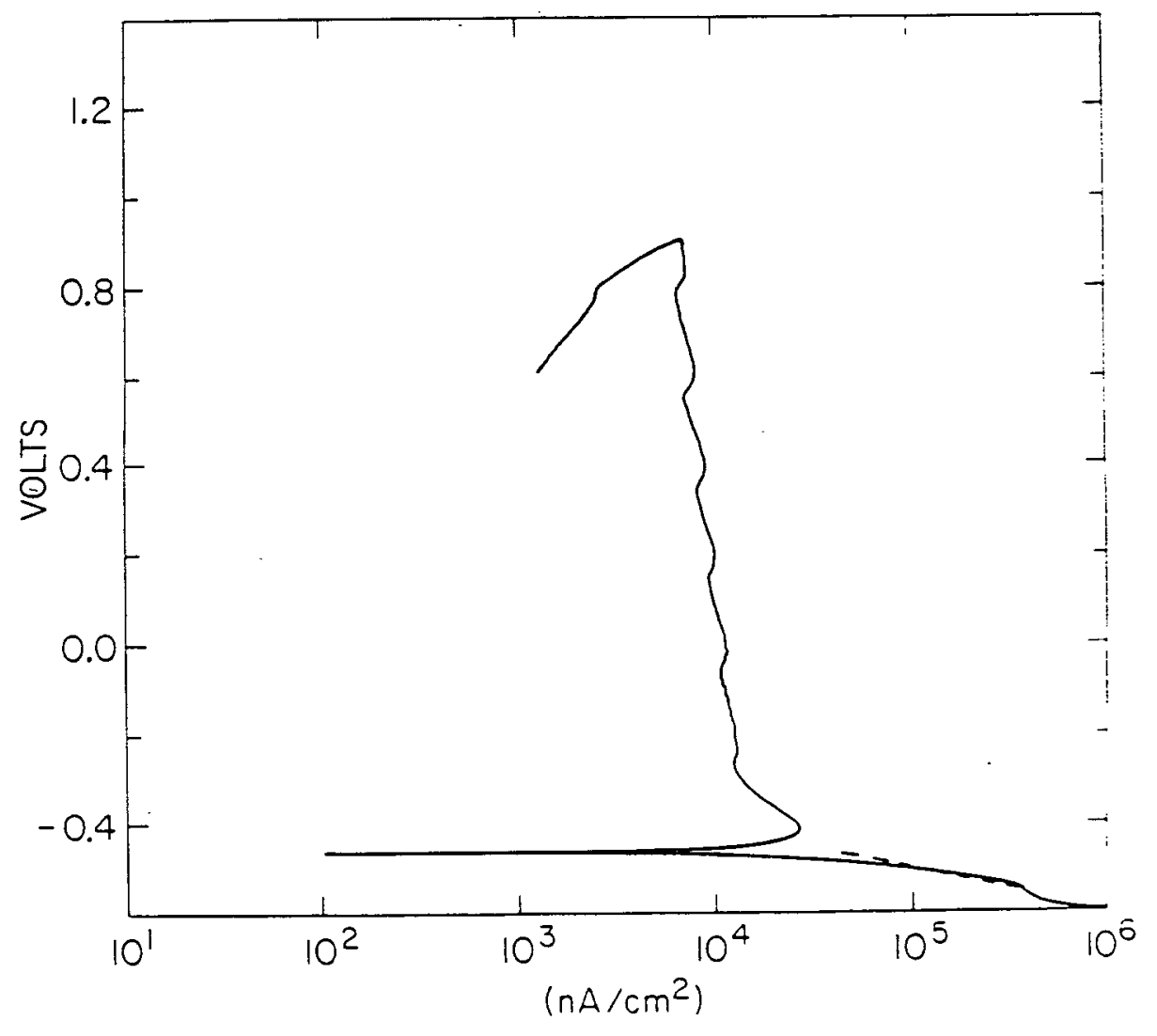

Figure 55. Ti-Code 12 in $0.5 \mathrm{~N} \mathrm{HCl}+2 \mathrm{~N} \mathrm{NaCl}$ at $70^{\circ} \mathrm{C}$. 